\title{
WHANGANUI KAIPONU: NGĀTI RUAKĀ METHODOLOGIES FOR THE PRESERVATION OF HAPŪ WAIATA AND ORAL TAONGA
}

BY

Meri Haami

A thesis submitted to the Victoria University of Wellington in fulfilment of the requirements for the degree of the Master of Music (MMus)

Victoria University of Wellington 


\section{Table of contents}

Title page

Abstract

$v$

Acknowledgements

$v i$

Ngā mihi $v i i$

List of tables

viii

List of figures

$i x$

Chapter One: Introduction

Section 1: Preface

1

Section 2: The research and significance of the study

3

Section 3: The meanings of kaiponu 4

Section 4: The ahi kā and whakapapa of Ngāti Ruakā 6

$\begin{array}{ll}\text { Chapter Two: Literature Review } & 17\end{array}$

Part One

Section 5: Waiata study within Aotearoa $\quad 17$

Section 6: Ngā mōteatea $\quad 19$

Section 7: Archival preservation methods 24

Part Two

Section 8: Oral history methodologies $\quad 25$

$\begin{array}{ll}\text { Section 9: Phenomenology } & 27\end{array}$

Section 10: Ethnomusicology and insider/outsider methods 28 
Section 11: Tikanga Whanganui

$\begin{array}{ll}\text { Section 12: Kaupapa Māori } & 37\end{array}$

Section 13: Music performance methods 43

Chapter Four: The research process with Ngāti Ruakā 46

Section 14: Collaborative consultation and participant recruitment 46

Section 15: Data collection $\quad 50$

Section 16: Data analysis 53

Section 17: Ethics $\quad 62$

Chapter Five: Ngāti Ruakā views and lived experiences of hapū oral taonga $\quad 64$

Section 18: Taonga and hapū identity $\quad 66$

Section 19: Whanganui kaiponu and sites of preservation 68

Section 20: Ethics and intentions 71

$\begin{array}{ll}\text { Section 21: Digital technology } & 77\end{array}$

$\begin{array}{lr}\text { Section 22: Participatory oral learning and teaching } & 80\end{array}$

Chapter Six: Ngāti Ruakā views in comparison to waiata literature $\quad 87$

Section 23: The significance of orality $\quad 87$

Section 24: The influence of technologies 93

Section 25: Kaiponu methodology, framework and ethics 100

$\begin{array}{ll}\text { Section 26: The ethical process } & 101\end{array}$

Section 27: The pedagogical methods 104

Section 28: Sites of preservation 106

$\begin{array}{ll}\text { Chapter Seven: Conclusion } & 109\end{array}$

Section 29: The research questions 109 


\begin{abstract}
This research explores Ngāti Ruakā perspectives on the preservation of hapū waiata and oral taonga, and it examines Whanganui kaiponu as a culturally appropriate methodology and research framework. Ngāti Ruakā perspectives are central to the study of hapū taonga within this research. This thesis also investigates the analysis of waiata through the decolonisation of western frameworks and methodologies on waiata study that have been used previously in ethnomusicology.
\end{abstract}

This journey led me back home to the ahi kā, my whānau (especially my Nanny, Angel Haami) as well as my hapū from the Whanganui awa. This further affirmed my own identity through whakapapa and the significance of tūrangawaewae. Through discourse with hapū members and throughout the interview process, karanga was gifted and performed as oral hapū taonga to me. The context of this research centres on the interdisciplinary bridging of ethnomusicology and waiata Māori studies.

This study highlighted critical aspects of preservation for Ngāti Ruakā concerning waiata. Hapū members raised issues relating to protection, transmission and pedagogy in regards to their hapū waiata or oral hapū taonga. This led to a need for re-establishing Whanganui kaiponu as a way of preservation and protection. 


\section{Acknowledgements}

I would like to thank the hapū, Ngāti Ruakā, especially the Rānana Māori Committee for your continual support, love and generosity throughout the research. This research would not have been able to go forward without everyone and it has been a privilege to work with my whānau and hapū. I want to thank Angeline Ann Haami, my Nanny for being patient with me, as well as the Chair of the committee, Rāwiri Tinirau, for your guidance. I wish to acknowledge my Nannies and Koro's who are the following Rānana Māori Committee members for your enormous contribution to this study; Kataraina Millin, Christina Tapa, Josephine Takarangi-Firmin, Evelyn Broad, Peter Broad, Tamihana Puketapu, Toreheikura Puketapu and Bernadette Hadfield. I have loved spending time with all of you and getting to know everyone of you.

To my parents; my Mum, Dr. Carole Ann Fernandez, you are my role model and inspiration by helping me to remember why I started this research, especially during the difficult stages; my Dad, Tumanako Haami, you have been supportive, loving and the most compassionate throughout the research. I wish to acknowledge my partner, Barnabas Cook, for keeping me grounded. My sisters and brother; Aroha Taimai, Kairi Watty, Piri Brown, Waimarie Taimai and Pita Haami - thank you all so much for reminding me to laugh and to not be so consumed with thesis work.

I wish to finally acknowledge my supervisors for your expertise; Dr. Brian Diettrich, thank you so much for you continual support, positivity and time you have put into helping me; Dr. Maria Bargh, for your time, your knowledge of tikanga as well as making me rise to this challenge. 


\section{Ngā mihi}

Tēnā koutou, tēnā koutou, tēnā koutou katoa

Ko Te Āti Haunui-a-Pāpārangi te iwi

Ko Ngāti Ruakā te hapū

Ko Aotea te waka

Ko Whanganui te awa

Ko Ruapehu te maunga

Ko Tamaupoko te tangata

Ko Meri Haami tōku ingoa

Tēnā koutou, tēnā koutou, tēnā koutou katoa katoa 


\section{List of tables}

Table 1: Waiata-a-rīnga of ahi kā 12

Table 2: Waiata aroha sub-genres $\quad 22$

Table 3: Waiata Mōteatea sub-genres

Table 4: Waiata tangi sub-genres 23

Table 5: Preliminary thematic analysis table 58

Table 6: Final thematic analysis table $\quad 61$ 


\section{List of figures}

Figure 1: Marae/pā map of the Whanganui awa 9

Figure 2: Whakapapa diagram of Tamakehu and Ruakā 10

Figure 3: Whakapapa diagram of Turi and Tamakehu 10

Figure 4: The identity of the hapū participants 53 


\section{Chapter 1.}

\section{Introduction}

Long ago, Māui Tikitiki and his brothers went fishing and hauled up Te Haha Te Whenua, the fish of Māui, the North Island. So mighty was this fish that Māui returned immediately to Hawaiki for help, leaving his awed brothers to safeguard it. In their fear they approached Ranginui, who told them: 'The mana of Te Ika a Māui can be subdued only by great mana. I give you Matua te Mana - Ruapehu.' This volcano, rising skywards in the centre of the new land, brought much-needed tranquility. But there was a problem for Ruapehu - loneliness and it was Ranginui who noticed. Ranginui laid two tear drops at Ruapehu's feet, one of which was to become the Whanganui River, the other becomes a story for other tribes to tell. But Ruapehu's sorrow deepened. He pleaded with Ranginui for companionship and, in time, Ranginui sent him four friends: Tongariro, guardian of the two teardrops, and Taranaki, custodian of the tapu for the clan of mountains. There was also Ngauruhoe, the servant of these mountain masters, and finally, Pihanga, the maiden mountain. Pihanga was spoken for as Tongariro's bride and the future mother of the continuing line for the mountain enclave. However, Pihanga was tempted by Taranaki. Eventually, heeding the advice of his brother, Ruapehu, Taranaki, wisely but sadly left the enclave. It was the only way he could ensure his tapu remained intact. Taranaki took the pathway that many mortals would later follow, down the course of the Whanganui River. At a western point in the river he stuck out towards the coast, settling by the ocean as the guardian of the setting sun. Here he remains, within view of the line of mountains of the central uplands from whom he stands in exile. And the Whanganui Awa continues to flow from Tongariro and down to the sea (Young, 1998, p. xi).

\section{Section 1: Preface}

The story above is a kōrero pūrākau written as a preface by Young (1998). This story provides one origin story for the creation of the Whanganui awa and it also serves to establish a scene for how whakapapa, tūrangawaewae, rangatiratanga and even 
aspects of ahi kā are interrelated with one another. These aspects can consolidate Māori and particularly Whanganui Māori specific realms of identity. Kōrero pūrākau is placed in the same category as waiata (Ka'ai-Mahuta, 2010: McRae, 2004). Therefore, in understanding Ngāti Ruakā waiata, oral histories and taonga, it is important to examine the social and historic context of this locale and hapū. The social and historic context provides a backdrop to Ngāti Ruakā specific formations of identity as well as Ngāti Ruakā cultural milieu.

It is important to further acknowledge that the above kōrero pūrākau is just one creation story out of many about and from the Whanganui awa and was approved by Whanganui iwi, as well as Ngāti Tūwharetoa and Ngāti Maniapoto (Young, 1998, p. 269). The approval and use of this kōrero pūrākau is illustrated within this chapter to show how these creation stories can also vary from each iwi, hapū and whānau.

Within the context of oral histories Young (1998, p. xi) demonstrated that different variations of oral story can exist concurrently due to a sense of equal yet simultaneous perspectives on a specific event, thereby showcasing multiple and diverse truths (Ka'ai-Mahuta, 2010). When a creation story moves from its oral state to a written format there is potential to limit its interpretation to one singular truth.

While written accounts of a creation story can be beneficial for hapū and iwi research it is always important to note the intent of the researcher, the ethical process in which they follow (that this is culturally appropriate to specific iwi, hapū or whānau that the story concerns) as well as the acknowledgement and acute awareness of the researchers own perspectives. These issues have implications within a range of areas 
regarding ethical standards, including how a story may be presented and perceived by readers or listeners and how the stories may conflict with other versions from differing iwi, hapū or whānau. This kōrero pūrākau seeks to contextualise the reader or listener in Whanganui history (Young, 1998).

This chapter presents the overall aims of the research relevant to the workings of waiata, kaiponu, Whanganuitanga and oral hapū taonga operating within the hapū Ngāti Ruaka. The first part of this chapter covers the research question and the significance of the study; the second part discusses the meaning of kaiponu; and the third explores the ahi kā of the hapū, Ngāti Ruaka. These three parts of the chapter provide an understanding of Ngāti Ruakā values, principles and beliefs that have affected the ways in which waiata has been and continues to be transmitted and preserved.

\section{Section 2: The research and significance of the study}

The broad research question this study sets out to answer is:

What are the ways in which Ngāti Ruakā want to preserve and transmit their waiata (hapū taonga) through kaiponu culturally appropriate hapū methodologies and frameworks?

This research contributes towards future members of Ngāti Ruakā as well as current hapū members. Its significance to me is of a personal nature, as I whakapapa from three iwi along the Whanganui awa, which include Te Āti Haunui-a-Pāpārangi (Henceforth Te Āti Hau), Ngāti Tūwharetoa and Ngā Rauru, and more specifically, I belong to the hapū, Ngāti Ruakā, who are the focus of this thesis. For the hapū, this 
research is a way for koroheke, kuia and other hapū members to share and express their lived experiences regarding waiata preservation as well as pass their kōrero on to their future and descending whānau members. Therefore, this research not only marks personal heritage but also honours my tūpuna as well as the progress that this research could make towards encouraging future Māori to undertake research within the ethnomusicology discipline, which has been dominated by Pākehā.

This research is intended to contribute towards the decolonisation process, in which Māori knowledge and epistemology (mātauranga) is reclaimed and presented within a Te Ao Māori context and way (Smith, 1999). This also presents issues encompassing the need and concept of preservation surrounding Māori knowledge as well as the necessity of outlining the ethics within the preservation process (Ka'ai-Mahuta et al, 2013). The methodology, using Whanganui kaiponu, may be adaptable for other hapū and iwi to use when studying their own oral histories, including waiata. This further contributes towards the concepts of ethical preservation, the components of decolonisation as well as popularising the idea of a non-homogenous view of Māori (Ralston, 1993; Smith 1997).

\section{Section 3: The meanings of kaiponu}

The term 'kaiponu' translates to withholding knowledge, refusing to let go or to keep to oneself (Māori Dictionary, 2017). This term has been used by Ngāti Ruakā to describe their way of preservation and view of hapu knowledge transmission and this is called Whanganui kaiponu (Interview, 2 April 2017; Rāwiri Tinirau, interview, 19 April 2017). Angeline Haami ${ }^{1}$ my Nanny, told me that the reference to Whanganui

\footnotetext{
${ }^{1}$ Angel Haami is a participant within this study and all of the participants have given permission to be identified
} 
kaiponu is that Whanganui people are generally known as being kaiponu and are often seen as "mean people" in that they are selective with whom they share their taonga with. $^{2}$

Kaiponu and its various meanings have been documented in relation to oral history, with waiata as its medium and particularly within the context of valuable knowledge transmission regarding warfare and politics (McRae, 2017). McRae (2017) finds this term used within waiata through letters conversing between George Grey and Te Āti Awa Chief, İhāia Pōrutu, which were written during the 1850s but are officially undated. These letters speak about the realities of living alongside Pākehā for Te Āti Awa iwi and kaiponu is used within this context to refer to meanness and withholding resources (GNZMA AL 761, n.d.). ${ }^{3}$ McRae (2017) makes a connection to Orbell and Finnegan's (1995) writings on the origin of kaiponu, as it translates to the idea of withholding knowledge due to an unwillingness to share. The story of kaiponu, according to Orbell and Finnegan (1995, p. 119), stems from a malevolent inhabitant of the underworld who brought misfortune to humans and was also known as 'kaiponu kino' or 'selfish-witholder.'

These meanings within the term kaiponu have negative emotional qualities and can represent an undesirable iwi and hapū position within politics and knowledge transmission. This is exemplified through Milroy (2008, p. 189) regarding iwi identity indicators with Tūhoe and sharing their taonga. ${ }^{4}$ Milroy (2008) identifies key issues surrounding Tūhoe identity in sharing taonga such as the contextual importance of

\footnotetext{
2 Taonga in this instance refers to the hapū specifc treasures of the associated rohe, iwi and hapū.

3 Letters between George Grey and Īhāia Pōrutu have been referenced by McRae (2017) as GNZMA AL 761, n.d.

4 This is an example of where 'taonga' is used as a term to encompass waiata as well as other knowledge mediums within an iwi specific publication (Milroy, 2008). Ka'ai Mahuta (2010) also refers to waiata as a type of taonga.
} 
oral taonga performances and the difficulties of passing these old traditions to rangatahi. Milroy (2008) highlights similar issues associated with Ngāti Ruakā taonga transmission and preservation concerns. Despite the differences in process, such as access or kaiponu between Ngāti Ruakā and Tūhoe, the concerns of performance context and the future knowledge bearers (rangatahi) still remain the same relevant issues for both iwi and hapū.

Although kaiponu has not been used previously as a guiding, entitling and formalised methodology, framework or method, it has been indicative of an iwi or hapū position regarding knowledge transmission of taonga (Milroy, 2008). This thesis however, uses the term Whanganui kaiponu as an integral framework to preserve Ngāti Ruakā oral taonga. The reason for its application towards ethical preservation of oral hapu taonga relates to Ngāti Ruakā definitions as well as my Nanny's stories of Whanganui kaiponu within the frame of 'meanness'.

\section{Section 4: The ahi kā and whakapapa of Ngāti Ruakāa}

Ahi kā is built from foundations that are specific to iwi and hapū affiliations and is a term that can be traced back to Kupe who was an early Māori explorer, migrating to Aotearoa (Buck, 1950). The Whanganui oral tradition states that Kupe said, "Kua kā kē nō ngā ahi" when he reached the mouth of the Whanganui awa, which means that the fires of occupation could be seen (Te Mana Matua Iwi, 1999). Kupe then travelled through the Whanganui awa, eventually settling in Mairehau, near present day Rānana and is where the hapū of Ngāti Ruakā hail from. The concept of ahi kā has changed over time and presently takes on different definitions between iwi, hapū and whānau 
that inform whakapapa, place, role, knowledge safe keeping and decision-making processes (Tinirau et al, 2009).

Ahi kā is important within Ngāti Ruakā as previous studies surrounding the historical definitions and applications of this term within the hapu have been conducted (Tinirau et al, 2009). Therefore it is vital to include and acknowledge this study, as it influences hapū participant views on waiata or hapū taonga preservation. The concept of ahi kā can help to examine pertinent origin stories of whakapapa through historical and social events through revealing how waiata and oral histories have operated within Ngāti Ruakā. This can indicate where the future of waiata and taonga could potentially proceed with current living hapū members and descendants. The whakapapa of Ngāti Ruakā will be explored below and this intersects with different aspects surrounding hapū definitions of ahi kā. These definitions include whānau and hapū claims to ancestral land bases told through oral histories, which in turn influences past and current legal land claims.

The people of Ngāti Ruakā are descended from and named after Ruakā who was the wife of Tamakehu. They had three children together who we highly regarded and therefore bestowed custodianship over three vital parts of the Whanganui awa (See Figure 2.). These three children and their subsequent jurisdictions of the Whanganui awa describe the three key ancestral groupings that connect hapū and iwi to one another. The upper section from Tongariro to Retaruke of the awa was designated towards Hinengākau (marked in Figure 1 as red). The middle section from Retaruke to Rānana was appointed to Tamaupoko (marked in Figure 1 as blue). The third and last section from Matahiwi to Pūtiki was given to Tupoho (marked in Figure 1 as 
green) (Simon, 1986). The unity of the Whanganui people is often referred to as, 'nga muka-a-taurawhiri-a-Hinengākau' or the fibre of the plaited rope of Hinengākau (McNeil, 2013; Sole, 2005; Young, 1998).

Although all of the Whanganui people are connected through Hinengākau whakapapa links it is important to acknowledge origin by sourcing those whakapapa connections through Tamakehu and Ruakā, as they are both central to the hapū, as well as other Rānana hapū and its identity (See Figure 2.). Further whakapapa links are shown from Turi to Tamakehu, as Turi migrated to Aotearoa through the waka, Aotea (See Figure 3.), again reaffirming a sense of identity. This can showcase the diversification of Whanganui hapū and illuminate the ancestral land bases of corresponding hapū and whānau through the marae/pā map (See Figure 1.). These aspects elucidate to further processes within Whanganuitanga and decision-making, such as ahi kā. Ahi kā can refer to either the ancestral land base or occupiers of the land bases who safeguard knowledge and are therefore significant in relation to waiata preservation and transmission (Tinirau et al, 2009). 


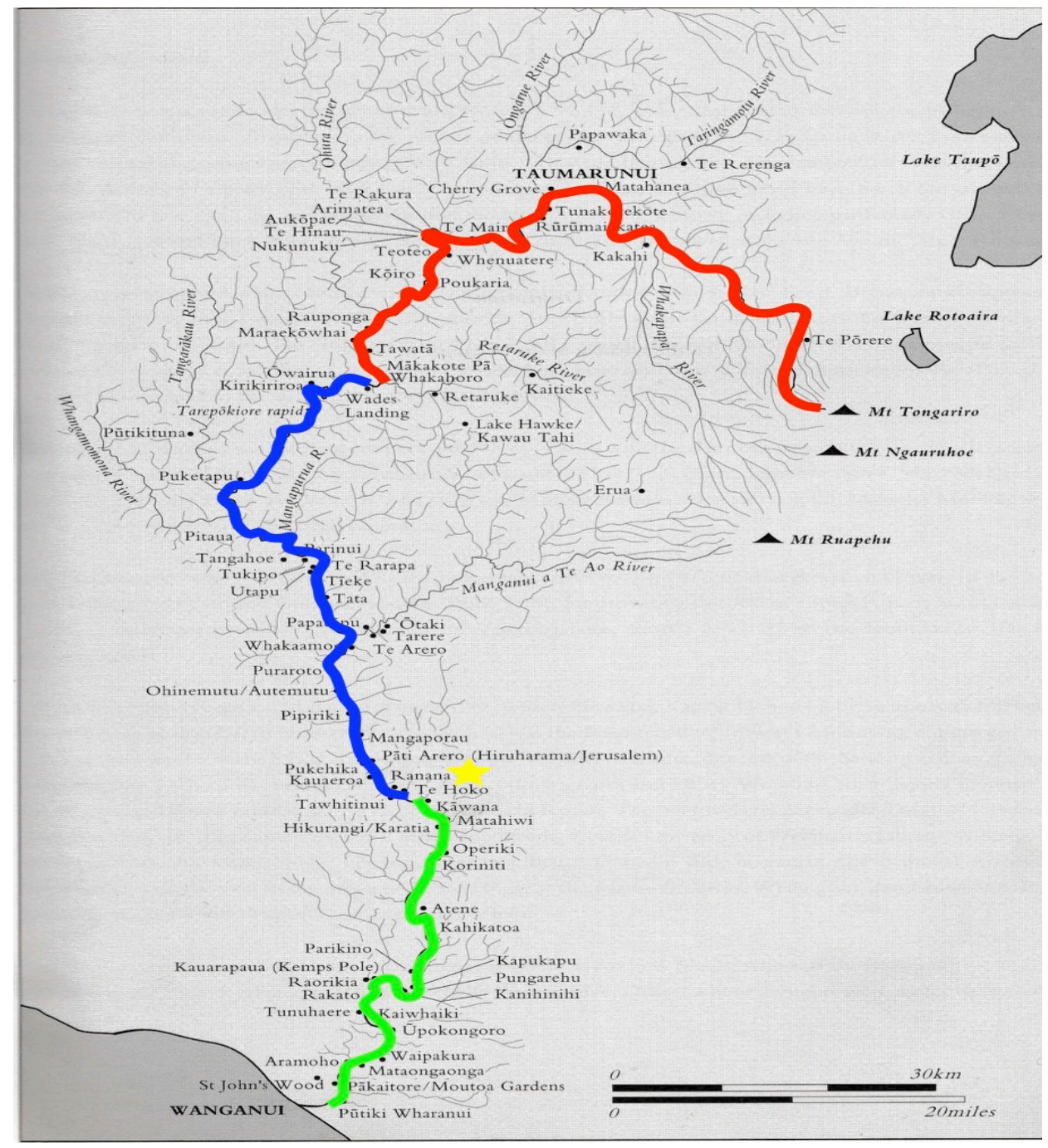

Figure 1. This Whanganui marae awa map is taken from the preface of Young $(1998, \mathrm{p}$. viii). It has been adapted to show the three ancestral groupings. Red shows Hinengākau, blue displays Tamaupoko and green is Tupoho. The yellow star marks Rānana, which is the residing place of the hapū, Ngāti Ruakā. 




Figure 2. This is an adapted whakapapa diagram showing the genealogical links of Tamakehu, Ruakā as well as Tamaupoko as it relates to Hori Paamu Whakarake Tinirau and Pare Blackburn. Both Hori Paamu Whakarake and Pare Blackburn are my great-great Grandparents (Tinirau, 2017, p. 66).

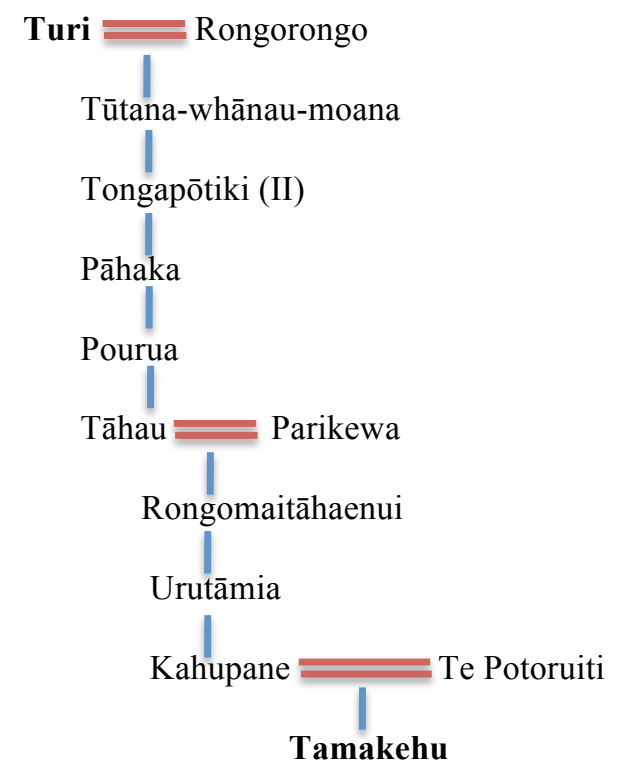

Figure 3. This is an adapted whakapapa diagram that shows the genealogical links of Turi through to Tamakehu. Turi migrated to Aotearoa through the Aotea waka and Whanganui people often reference Turi (Whanganui Iwi and the Crown, 2014, p. 13-14). 
Ahi kā was prominent evidence used as a part of a 'take', which referred to the customary right Māori had over their estates (Tinirau et al, 2009). This definition of take is outlined by the Royal Commission of Inquiry (1980, p. 9),

The possession of land, even for a number of years, did not confer a right unless the occupation was founded on some previous take (i.e. root or basis of title) of which the occupation could be regarded as a consequence; and this take must be consistent with the ordinary rules governing and defining Māori customs.

Smith (1960) reiterates three other important take rights of the land, which include take tīpuna (ancestry), take tuku (gift) and take raupatu (conquest). These three take rights required similar proof to ahi kā, however ahi kā was considered an "act indicative of ownership and use", while also meaning continuous land occupation and where the home fires had not been extinguished (Firth, 1959; Kawharu, 1977; Rikys, 2001; Salmond, 1976; Sinclair, 1981; Smith, 1942, 1960, p. 94; Tinirau et al, 2009; Toitū Te Whenua, 1959; Williams, 1999).

The text below (See table 1) in both te reo Māori and English illustrates a waiata-āringa $^{5}$ (Apou, 2003). This waiata demonstrates the different meanings of ahi kā from a contemporary perspective, as it has encompassed many definitions and applications throughout history. ${ }^{6}$ This has primarily referred to continuous land occupation of the ancestral land base as well as a 'take' in Native Land Court claims (Tinirau et al, 2009). This waiata acknowledges both of these historical meanings of ahi kā in reference to descriptors such as "maintaining treasures", "sweat and labour" as well as "earn[ing] the right to be ahi kā." These descriptors refer both to a literal place and a

\footnotetext{
5 Waiata-ā-ringa refers to an action song.

6 This waiata was observed and used as supporting oral histories within a Tinirau et al (2009) publication about ahi kā. The Aotea Utanganui Group first performed this waiata-ā-ringa during Te Matatini Kapa haka National competition in 2005 .
} 
figuratively constructed role of decision-making processes that is still an active part of the hapū community.

\begin{tabular}{|c|c|}
\hline Manaaki mai te tangata & Caring for the people \\
\hline Kia ora mai te wairua & Lifts the spirit \\
\hline Tiaki mai te tangata & Looking after the people \\
\hline Ara ko te tohu o te ahikā & This is the sign of the ahi kā \\
\hline Ka kite atu ai i ngā mahi nei & You have experienced the labour and sweat \\
\hline He taonga tuku iho i ngā mātua & To maintain the treasures handed on from elders \\
\hline E mārama nei koe me whakapupuri & You understand that you must take hold of these things \\
\hline Kia hurihia koe hei hunga ahikā & To earn the right to be ahikā (Apou, 2003). \\
\hline
\end{tabular}

Table 1: Waiata-ā-ringa performed by Aotea Utanganui Group during the Te Matatini Kapa Haka National competition, 2005.

Within the Native/Māori land Court there were three ways in which claimants proved ahi kā. The first and second way included the confirmation of connections and knowledge of the land, such as genealogical links with tūpuna who had lived on the land as well as providing topography and history. The third and final way was to prove that the ancestral flame was kept alive through current utilisation and occupation of the land (Tinirau et al, 2009). Smith (1942) expands on the rights of ahi kā, adding that these should include activities such as hunting, fishing, cultivations and bird snaring and that ahi kā rights should be protected over time and therefore retained. Asher and Naulls (1987, p. 22) reinforce this expanded meaning surrounding the rights of ahi kā while linking it to its traditional meaning:

The principle of ahi kā or right of occupation and use was most important in traditional Māori society. It confirmed and was a co-requirement of all other rights to land. But while occupation was often cited as a necessary means of maintaining 
ownership over land, this could also be done by cultivating the land or by collecting food and other resources from it.

Explicit notions of ahi kā have been explored to measure one's connection to their ancestral land base as well as its continual physical occupation. These explicit notions measure ones relationship to ahi kā through two ways. The first is called 'ahi tere' and this means an unstable fire through relocating away from the ancestral land base. This can include marrying and having to move outside of one's tribal area. If one's ancestral flame is unable to be rekindled within the grace period of three generations then one moves into the second notion called 'ahi mātaotao'. Ahi mātaotao refers to a cold flame and where one's flame has been extinguished, therefore the connection and rights to the land are lost (Sinclair, 1981; Smith, 1942, 1960; Tinirau et al, 2009; Toitū Te Whenua, 1959).

The critiques of these explicit notions surrounding ahi kā comment on the need for understanding, as outside historical interactions as well as social factors including the availability of land and its resources contribute towards someones ahi kā (Boast et al, 2004). An additional critique could be seen through the lens of contemporary Māori realities regarding the influences of colonisation and imperialism through past governmental policy: not all Māori have had the opportunity to reconnect with their identity as Māori whether that be through understanding their whakapapa, whānau, going back to their marae, hapū or wider iwi. These notions of ahi kā within this context may not be able to properly articulate diverse Māori experiences of identity. Māori also living away from the ancestral land base and facing difficulty in travel can affect the measuring of one's connections to their marae and hapū (Tinirau et al, 
2009). Again these explicit notions may not be able to appropriately express the link that one feels to their identity as Māori or level of contribution to their marae or hapū.

Ngāti Ruakā used ahi kā as evidence within the Māori Land Court during several cases $^{7}$ (Tinirau et al, 2009, p. 13),

In all the cases where lands in and around Rānana were discussed, speakers presented whakapapa to show descent from known ancestors linked with the various lands.

They explicitly described the boundaries, villages, houses, burial grounds, guardians, cultivations, bird snaring places, trees, stones, tributaries, hunting and fishing grounds, canoes, hills, battles and feasts. They debated the interconnections between the hapu groupings associated with the land, and recalled various accounts that were pertinent to the histories of those hapū.

The Waitangi Tribunal (1999, p. 35, Wai 167) concludes that the conceptual significance of ahi kā is one that is predominated by connections,

The lands of the people, then, are defined not by boundaries but by relationships. The identifiable lands of a group of Māori people are the lands of their history, the places where their tippuna are buried, all those lands that they could occupy or defend, or on which they could keep their fires alight.

It is within this statement that the notions of ahi kā in terms of its descriptors surrounding fire and whether or not this fire is kept alight, acts as an allegory to a person's relationships and connections, with ahi kā being the fire that is the connection to a particular ancestral land base.

\footnotetext{
7 This specific court cases are included within the bibliography as well. These include; Māori Land Court, 7 May 1900, Whanganui Minute Book 44; Māori Land Court, 21 May 1900, Whanganui Minute Book 44, p. 348-349; Māori Land Court, 19 February 1901, Whanganui Minute Book 47, p. 199; Māori Land Court, 1 March 1909, Whanganui Minute Book 59, p. 80-86.
} 
World War II and the urbanisation of Māori influenced the definitions of ahi kā

(Tinirau et al, 2009). During this urbanisation period, many Māori left their ancestral land bases towards urban cities, thus hastening the disintegration of rural communities leaving migrated whānau members "culturally dislocated - a form of ahi tere" (Tinirau et al, 2009, p. 13). Ahi tere can result in whānau members that are fourth or fifth generation evolving to a state of ahi mātaotao: becoming permanently displaced from their ancestral land base.

It became commonplace for those of kin (relatively far removed) to keep the ancestral flame burning by occupying the land base on the behalf of the current generation who live elsewhere,

Therefore, the definition of ahi kā has expanded, and acknowledges that genealogical ties, no matter how distant, can act as a conduit to the ancestral flame for Māori urban dwellers (Tinirau et al, 2009, p. 14).

Tinirau (et al, 2009) contests the explicit notions of ahi kā (ahi tere and ahi mātaotao) in this expanded definition in terms of whakapapa links. This acknowledgement of whānau members who still occupy and live on the ancestral land base is referenced within the waiata-ā-ringa stated previously, which illustrates appreciation for ahi kā whānau members (Apou, 2003).

Furthermore, ahi kā is a role in Ngāti Ruakā as well as a place, which is also central for a legal argument or position regarding land rights:

Generally speaking, those who are resident on the tribal homelands, as well as having the responsibility and prerogative to maintain the ahikā, become known as the ahi kā. As such, their main role and responsibility includes upholding and maintaining both the tikanga (custom and practices) on the marae, and the marae itself. As 
acknowledged by the wider hapū community, this role is paramount, for without ahi kā, the marae and its associated tikanga may become subject to neglect (Tinirau et al, 2009, p. 16 cited in Tinirau et al, 2007, p. 122).

Ahi kā as a role within Ngāti Ruakā incorporates continuous land occupation in conjunction with looking after and keeping the knowledge of marae tikanga in tact on the behalf of whānau urban dwellers; therefore this gives ahi kā greater responsibility in terms of decision-making (Tinirau et al, 2009). The role of ahi kā becomes integral within decision-making processes in relation to navigating how knowledge should be transmitted presently and this occupies spaces of specific hapū oral history and waiata.

\section{Summary}

This chapter examined the overall aims of the research, the meanings of kaiponu and ahi kā. This introduction provides the contextual understanding to Whanganui kaiponu and ahi kā and its relevance to preserving hapū oral taonga. 


\section{Chapter 2.}

\section{Literature Review}

\section{Introduction}

The literature review will be divided into two parts: the first will examine the area of waiata study within Aotearoa exclusively and relate pertinent literature to past waiata studies. The second part will explore interdisciplinary methodologies, methods and frameworks that have been used to study waiata in both national and international contexts. The first part covers a brief historical overview of waiata study within Aotearoa; a case study examining the ways in which Ngā Mōteatea came together and was studied through ethnomusicological methods; and lastly, archival preservation methods, which provides an overview of the legality surrounding copyright and intellectual property of indigenous music. The second part explores oral history as a methodology, phenomenology, and lastly, ethnomusicology as well as insider/outsider methods. This entire literature review aims to illuminate the historical context surrounding waiata study within Aotearoa and to further inform the understandings of Ngāti Ruakā perspectives on waiata preservation methods.

\section{Part 1}

\section{Section 5: Waiata study within Aotearoa}

Early colonial research of an anthropological nature during the first arrivals to Aotearoa by European settlers studied waiata and Māori music (Andersen, 1923, 1924, 1934, 1946; Grey, 1853, 1857a, 1857b, 1971; Taylor, 1855; Best, 2005). These publications sought to reveal the musical and sonic aspects of waiata, taonga pūoro and technique in relation to their background within western music. The writers' 
experiences within western music made them ill equipped for studying Māori music due to their application of western frameworks.

Ka'ai-Mahuta (2010) analysed early colonial waiata study based on the works of Grey (1853,1857a, 1857b, 1971, p. vi-viiii), Andersen (1923, 1924, p. 24, 1934, 1946), Power (Best, 2005) and Taylor (1855). Grey (1853,1857a, 1857b, 1971, p. vi-viiii) was the first to install a large body of Māori knowledge, including waiata within a western academic context; he however did so by hypothesising from his own Eurocentric worldview and Christian influence. Andersen (1923, 1924, p. 24, 1934, 1946) compares waiata as well as many other indigenous oral art forms to western forms of tonality, such as scales and harmony. According to Ka'ai-Mahuta (2010) Andersen and Grey reduce Māori to ideals of primitivism, which are a consequence of imperialist worldview and a lack of understanding. Power in Best (2005) compares Māori to concepts of monoculturalism and the music is subsequently met with dismissal. However, Ka'ai-Mahuta (2010) notes that there did exist research that preferred other methods and worldviews, one being Taylor (1855). Taylor (1855) examined the contextual elements of waiata, which included the stories that preluded them, the ideas within them as well as their overall purpose. These are significant elements Māori tended to favour, however this was largely excluded from the works of Grey, Andersen and Best (Ka'ai-Mahuta, 2010).

Worldview is an integral part of research and the aforementioned researchers' inability to understand the nature and purpose of waiata can highlight the dangers of applying entirely western frameworks of tonal and musical analysis onto waiata (Ka'ai-Mahuta, 2010). These dangers can include misconstrued information, call 
attention to only partial elements and exclude significant aspects that are integral in experiencing and understanding the cultural concepts as a whole. The compositional and technical characteristics of waiata were not the most important aspects for Māori: rather it is the words, narratives and messages compiled within the waiata that are central (Ka’ai-Mahuta, 2010; Royal, 2003).

\section{Section 6: Ngā mōteatea}

Tā Āpirana Ngata $(2004,2005,2006,2007)$ curated the Ngā Mōteatea series in an effort towards preservation for Māori by Māori and as a response to an application. This application attributed Ngā Mōteatea towards a body of work required for the inclusion of Māori Studies within a Bachelor of Arts degree (Benton, 1981). Pei Te Hurinui Jones aided Ngata in the series for his extensive knowledge of stories and for English translations (McLean, 2004). Hirini Moko-Mead (Ngata, 2008) also translated the fourth volume of Ngā Mōteatea. This series includes a vast collection of waiata and their stories from various iwi and hapū throughout Aotearoa and became a seminal work within the study of waiata.

This series created the basis for works by prolific ethnomusicologist Meryvn McLean and music historian, Margaret Orbell. The extensive works of Mervyn McLean in particular seems to have overshadowed the need for change within ethnomusicology study on Māori music as well as the study of waiata. The term 'change' refers to the necessary and constant exploring, challenging, learning and revision of methods, processes and principles required for the development of a particular field. McLean's methods, processes and worldviews however resonate with early ethnomusicology frameworks evocative of colonial viewpoints, which can stifle new ways of 
examining waiata. One example of this is his use of traditional transcription, which is a largely outdated system of recording musical 'works' within international ethnomusicology presently and consists of ear to hand notation. Despite its mostly demoted use internationally, this system is used by McLean within his works and is a system he continually supports throughout his publications (McLean and Orbell, 1975; McLean, 1989, 1996, 2004, 2006, 2013).

Ka'ai-Mahuta (2010) critiques McLean's traditional transcription methods (and Orbell, 1975, 1989, 1996, 2004 2006, 2013) highlighting McLean's omissions, mistakes and re-interpretations of waiata, which are a result of poor transcription design. Ka'ai-Mahuta (2010) takes on the enormous task of analysing waiata study within the context of Aotearoa. Her work examines the historical and socio-political context of waiata through a contemporary lens by chronologically examining the precolonised oral tradition of waiata functionality through to the digitalisation of waiata archiving. This culminates in a national and digital repository for waiata and haka called 'Tāmata Toiere' (2010, p. 254-299). This digital repository utilises not only contextually driven approaches but also audio recordings and digital computer-based technologies.

The national and extensive focus of Ka'ai-Mahuta's (2010) work shows signs of movement from early waiata work by Ngata $(2004,2005,2006,2007)$, McLean and Orbell (1975). These works can also encourage discourse, as there is no formalised society of waiata study within Aotearoa. This could also be said for ethnomusicology of Māori music nationally too, where issues surrounding ethical and culturally appropriate methods can be discussed openly and together. Due to Ka'ai-Mahuta's 
(2010) broad research topic, ethnomusicology could not be examined more comprehensively. A recent publication (Ka'ai-Mahuta et al, 2013) contains an assortment of articles both in te reo Māori and English and allows for expertise from many disciplines on waiata study to be examined more closely. Further ethical considerations surrounding digital technology in both audio and film formats as preservation for specific iwi, hapū and whānau is a facet that also needs to be analysed, as Māori may have differing viewpoints on how it is used and by who. This perspective can be placed within the context of Whanganui kaiponu, as the converging of digital and traditional yet restrictive methods of waiata transmission calls for further discussion.

Ngā Mōteatea laid the foundations for future ethnomusicologists, anthropologists and music historians alike to further categorise the waiata collected through similitude within structure, sound, subject matter and form to formulate a catalogue of genres (Ngata, 2004, 2005, 2006, 2007; Orbell, 1991; Moorfield and Johnston, 2004; McLean and Orbell, 1975). The sub-genres outlined below are under the three main waiata genres along with their meanings (See Table 2, 3 and 4). Waiata genres are determined through functionality, song form, rhythmic qualities and appropriateness to a situation. Waiata has also been categorised into sub-genres (Orbell, 1991) created from the Ngā Mōteatea series (Ngata, 2004; 2005; 2006; 2007). The tables use primarily Orbell's (1991) waiata sub-genre categorisations along with other scholars and these have been formulated in the three tables below (Ngata, 2004; 2005; 2006; 2007; Moorfield and Johnston, 2004; McLean and Orbell, 1975). These tables demonstrate established ways in which waiata have been categorised through a western ethnomusicological lens. 


\begin{tabular}{|l|l|}
\hline Ruri & Amorous and lustful songs \\
\hline $\begin{array}{l}\text { Mō te moe } \\
\text { punarua }\end{array}$ & Songs for two wives \\
\hline Aroha & Love songs \\
\hline Whaiāipo & Bold and highly flirtatious love songs \\
\hline Wawata & Expressing desire for another person \\
\hline $\begin{array}{l}\text { Whakautu tono } \\
\text { pākuwhā }\end{array}$ & Marriage proposal song \\
\hline \begin{tabular}{l} 
Pātere \\
\hline
\end{tabular} & Dealing with jealous slander \\
\hline
\end{tabular}

Table 2: Waiata aroha sub genres -waiata aroha, whakautu tono pākuwhā in particular has the meaning of 'marriage proposal', however this translation can be contentious, as the term 'marriage' from its Christian perspective and connotations did not exist formally within a pre-colonial time for Māori. It is quite possible that this genre was created during the time of the arrival and influence of Christian missionaries throughout Aotearoa or perhaps this translation was given due to there being an absence of the proper term that could have been better suited.

\begin{tabular}{|c|c|}
\hline Haka & $\begin{array}{l}\text { Dance and action songs that are very percussive and chant of } \\
\text { war }\end{array}$ \\
\hline Matakite or mata & Prophetic songs where visions are communicated \\
\hline Poi & $\begin{array}{l}\text { Chant-like action songs accompanied with a poi (performance } \\
\text { device) }\end{array}$ \\
\hline Nā te tūrehu & Songs originating from earth-spirit or referred to as 'fairy-folk' \\
\hline Oriori or pōpō & Lullabies or short songs \\
\hline Pao & $\begin{array}{l}\text { Short chanting songs used for entertainment. The subjects can } \\
\text { include and is not exclusive to, love, gossip and scandal. }\end{array}$ \\
\hline Tuki waka & Paddlers' songs, which are sung from the waka \\
\hline Karakia & Ceremonial, deeply spiritual and ritualistic prayers and songs \\
\hline Kaioraora & Defiant and cursing songs \\
\hline $\begin{array}{l}\text { Whakautu } \\
\text { whakapae }\end{array}$ & Response songs to a statement made against someone \\
\hline Whakaaraara pā & $\begin{array}{l}\text { Watchers' songs, which are sung by watchers' looking over the } \\
\text { pā throughout the day and night }\end{array}$ \\
\hline
\end{tabular}

Table 3: Waiata Mōteatea sub genres - this table shows the sub-genres used within Orbell's (1991) waiata sub-genre categorisations that have been put together from the Ngā Mōteatea series and only highlight one way of viewing waiata categorisation (Ngata, 2004, 2005, 2006, 2007). 


\begin{tabular}{|c|c|}
\hline Apakura & $\begin{array}{l}\text { Laments sung and composed by women within the wharemate during } \\
\text { the tangihanga }\end{array}$ \\
\hline $\mathrm{n} / \mathrm{a}$ & Loss of chiefs and warriors loss and death in battle \\
\hline $\mathrm{n} / \mathrm{a}$ & Loss of chiefs caused by natural death \\
\hline $\mathrm{n} / \mathrm{a}$ & Death of a husband, wife, partner and/or child \\
\hline $\mathrm{n} / \mathrm{a}$ & Loss of husband, wife and/or partner to another lover \\
\hline $\mathrm{n} / \mathrm{a}$ & Lament for people who have died in an accident \\
\hline $\mathrm{n} / \mathrm{a}$ & Laments for cause of affliction \\
\hline $\mathrm{n} / \mathrm{a}$ & $\begin{array}{l}\text { Laments for the death of an iwi, rotted crop, abandoned land or } \\
\text { damaged waka }\end{array}$ \\
\hline $\mathrm{n} / \mathrm{a}$ & Laments for people murdered by treachery \\
\hline
\end{tabular}

Table 4: The table of waiata tangi shows a 'not applicable' symbol showing that these sub-genres did not have an overall name, rather that these are the types of waiata tangi that exist.

It is important to acknowledge that McLean $(1975,2006)$ and Orbell's $(1975,1991)$ works within the context of waiata study sought to categorise waiata into genres, as this was apart of early musicological approaches on western music. This was subsequently used on non-western music in attempts to make sense of 'foreign ways' of musicality. This again can reaffirm the risks of viewing waiata from solely a western lens, which can result in restrictive findings (Ka'ai-Mahuta, 2010).

Applying the concept of genre to waiata reveals subtle similarities within the perception of categorical difference (Holt, 2008), as this can be found within some instances of waiata. Specific functions of waiata, which are guided by the messages, histories and narratives encapsulated within them, are important within Māori society (Ka'ai-Mahuta, 2010). For example, oriori considered as lullabies are primarily meant for tamariki and were used by kuia to teach and pass on the histories of the iwi to their 
mokopuna (Binney and Chaplin, 1986). While genre, as a means of classification is not central to the model of viewing waiata, as Māori did not formally organise waiata through a fixed genre-based approach nor did they have a term for such, there are similarities within the way genre is bound to categorical difference.

\section{Section 7: Archival preservation methods}

The categorisations of waiata within a genre-based system have helped in the memorisation of waiata preservation, storage and archiving, particularly favourable among ethnomusicologists who have studied waiata. Ethnomusicologist, Seegar (1996) whose publication touches on archival preservation methods offers relevant arguments pertaining to these aforementioned areas. It is important to acknowledge that this publication could be outdated within the context of technology and law, as it was published over twenty years ago.

Seegar (1996) critiques the ways in which ethnomusicologists examine their studied music within the context of legality, copyright and intellectual property. Seegar (1996) makes practical suggestions for ethnomusicologists stating that the music and performance that they work with should be in accordance with laws protecting commercial musicians. Some of these suggestions include; archival systems having an "image problem" (Seegar, 1996, p. 89-90) and the need to reconsider the copyrights expiring for music stored in archives from ethnomusicology work as well as an awareness that copyright laws differ from country to country with the interests of its indigenous population not being important to the creation of such laws. 
These ethical safeguards that have been specified by Seegar (1996) can be beneficial as a type of template for protecting Ngāti Ruakā waiata or oral hapū taonga, as they have stated their future concerns regarding this area for audio recordings that have been preserved within an archival sense (Focus group, interview, 2 April 2017). However issues can arise through the extent to which audio technology is used for preservation methods, if the waiata is preserved through an archival system as well as New Zealand law governing copyright and intellectual property.

\section{Part 2}

\section{Section 8: Oral history as methodologies}

Oral history has become its own field of study, built towards methodological and framework studies within qualitative research. Oral history methodologies have been adapted and integrated as a type of historiography (Henige, 1982) and an example of this is through the work of Leavy (2011). Leavy (2011) aims to create more contemporary research designs, concepts, strategies and methodologies surrounding oral history stemming from the anthropological roots of qualitative research. Its emphasis is on the perspectives of the participant and entails multiple open-ended interview sessions with each participant. Leavy (2011, p. 11) also goes on to acknowledge its connection to the oral tradition and the mutually explorative nature of oral history methods stating,

Oral history is based in an oral tradition of transmitting knowledge. In essence, this method presupposes that individual actors have valuable knowledge to share based on their life experiences, including their behaviors, rituals, attitudes, values and beliefs. It is during an open-ended, highly structured series of interviews that the researcher and participant engage in a process whereby these experiences are unearthed, reflected on, interlinked, and knowledge is collaboratively created. There, data 
generated from the perspective of the research participants who work jointly with the researcher. Meaning develops out of this collaborative process.

Oral history methodologies are almost commonplace and a well-established field of inquiry within an international context. However within the context of Aotearoa, "it remains a clouded and [an] unresolved area of study on our own shores" (Mahuika, 2009, p. 91). Mahuika (2009) describes many aspects of oral history, including the relationship that it shares with the oral tradition, its view and use as a methodology as well as the centralisation of the interview process.

Mahuika (2009) additionally explores how the theoretical and methodological developments in oral history can be applied to a Kaupapa Māori framework, Oral history theory and practice offers varying opportunities in support of Māori research if we take the time to see their potential and make the connections. A deeper consideration reveals a more intense critique of oral history and tradition and simultaneously engages with the impact of literacy on the orality of Indigenous oral transmission. Oral history theories provide new literature to assist in the way we might argue for individual agency, subvert collective constructions and understand collective memory (Mahuika, 2009, p. 100).

The last sentence in particular offers insight into the way in which oral history in the past has always played an integral role within Māori society and relates to oration forms, such as waiata, as they were used in these ways as stated by Mahuika (2009). Mahuika (2009, p. 100) places the previous role of oral history within the realm of contemporary methodologies for Māori, by stating its potentiality for providing new perspectives and array of literature that can be beneficial in providing multi-faceted views on complex issues. 
Māori value oral history methodologies however its processes are often criticised (Mahuika, 2009; Mutu, 2009). Ka'ai-Mahuta (2010, p. 49) examines this doubt of certain processes through Finnegan's (1977) work on oral histories, arguing that Finnegan (1977) dismisses the legitimacy and authenticity of oral history methodologies due to the precise wording being changed from person to person. Ka'ai-Mahuta (2010) highlights that there are suitable oration forms, such as waiata that work to remediate Finnegan's (1977) critique. Ka'ai-Mahuta (2010, p. 49-50) also discusses the communal nature of the oral history as belonging to iwi and therefore different iwi will have differing versions of oral histories; whereas, Finnegan (1977) could not connect this in relation to specific intricacies, protocol and customs of specific iwi.

\section{Section 9: Phenomenology}

Phenomenology examines "the organization of awareness between time and space, relationships between self and other in experience, the distinctive ways that body emerges in experience, and a wide range of other experiential structures" (Berger, 2010, p. xi). Phenomenology has been used within areas such as ethnomusicology, performance studies, ethnography and anthropology but more recently resurfaced particularly among interdisciplinary studies that strive to illuminate particular meanings, trends and experiences within expressive cultures (Berger, 2010; Herbert, 2010; Holmes and Holmes, 2010; Robbins, 2011; Downey, 2002). 
The complete adaption of phenomenological methods into Kaupapa Māori as well as tikanga Whanganui ${ }^{8}$ can cause implications to the principles of kaiponu for Ngāti Ruakā. These implications may be due to residual caution of phenomenology as a discipline surrounding its "colonialist heritage," which was used to justify differentiations of cultural groups (Berger, 2010, p. 6).

Phenomenology contains meticulous vocabulary (Berger, 2010) and in terms of this specific study can possibly constitute, translate and mean different things for members of Ngāti Ruakā. However there are valuable parts of phenomenological frameworks that involve the understanding of how the significance and meaning of music situated within cultural groups lived experiences can be brought out through participatory means. It is these partial aspects that can be adapted and prove beneficial in articulating deeper understandings within particular ways of learning and processes that reveal distinct meanings for Ngāti Ruakā.

\section{Section 10: Ethnomusicology and insider/outsider methods}

Ethnomusicological methods involve forming collaborative relationships with participants. The formation of relationships made during the fieldwork process is exemplified within Nettl's $(1964,1975,1983)$ works; these include ethical considerations but also with more areas within ethnomusicological study. One concept includes the notion of reciprocity in relation to ethics. Hellier-Tinoco (2003) has cited a paucity of reciprocity in ethnomusicology scholarship and believed it was most likely due to the personal, natural and intimate nature of relationships formed

\footnotetext{
${ }^{8}$ Kaupapa Māori is the overall methodological approach for this study and tikanga Whanganui is the ethical framework. This is explored comprehensively within the methodogies chapter (See page 34).
} 
during the study and interviewing process. This can result in separated lives in both academia and in the field that is experienced by the researcher,

If the academy is separated from the world at large, where does our fieldwork, which is so intrinsically part of real lives and real experiences, fit into such a context? The issues are intimately related to how we regard our own field research: whether it is "simply" one element of an academic project, compartmentalized as part of academic life, with the result that we view the friendships and other relationships in the same way, or whether it is a normal part of our everyday lives (Hellier-Tinoco, 2003, p. 28).

Although there are varying ideas on reciprocity among anthropological scholars, there is consensus on the need for realisation, acknowledgement and further supportive processes around reciprocity within the fieldwork relationship context (HellierTinoco, 2003). Some notions of reciprocity include the services being rendered through financial, economic or product-based remunerations, as well as envisioning the researcher as a kind of cultural advocate, broker or intermediary for the benefit of lives within music-cultures (Sheehy, 1992; Davis 1992). Reciprocity is underlined with the principles of creating "social and political activism, a kind of musical activism" (Nettl, 1983, p. 10).

However, within these principles of reciprocity, lies a degree of separation, or a “dichotomy between 'scholarship' and 'experience"” (Kisliuk, 1997, p. 24). The potential for conflict arises when relationships formed during the course of fieldwork become too personal or entwine with the researchers 'real life'. This can cause conflict with the way in which the researcher compartmentalises their own relationships, realities and identities (Hellier-Tinoco, 2003). The nature of 
relationships can influence the perception of the 'field' and the 'fieldworker' and its change over time. These two constructs were used to help narrow the researchers inquiries and identities. However this can be limiting for some researchers, as it does not fully articulate the changing of identities and inquiries within a non-home environment (Kisliuk, 1997).

Hellier-Tinoco (2003, p. 28) reiterates the limitations of these two constructs by stating, "if there is a separation between scholarship, fieldwork and life, then intrinsic to such separation are notions of our identity and role in each context and the identity and role of those with whom we form relations." Hellier-Tinoco (2003) and Kisliuk (1997) both suggest that these constructions of the 'field' and the 'fieldworker' can be viewed as experiences rather than places and that the 'field' is an illusion. This illusion is what some believe could be the primary cause for the conflicts highlighted between the rigid dichotomy of the 'scholarship' and 'experience' separation.

Another important dichotomy and factor to consider is the researcher's position within the research as a cultural insider or outsider. Bartunek and Louis (1996) use an interdisciplinary case study approach to examine the ways in which these often problematic and restrictive positions can be shifted to a joint and mutually beneficial research method.

Bartunek and Louis (1996, p. 10-11) examine their conceptual basis for the joint insider/outsider research method by deconstructing an internet message from June 1994 sent by a Canadian education administrator, Lloyd Ryan regarding an action research bulletin. This story is quite long, however the analysis of the story by 
Bartunek and Louis (1996) conveys further viewpoints on the intricacies of this insider/outsider dichotomy. One intricacy that is exemplified from Ryan's story is the paradoxical relationship felt by Ryan of being a cultural 'insider' and the anthropologists being the 'outsiders' studying a culture from which he belongs too, Beyond these parties, Ryan himself is in a unique position. In relation to the anthropologists, he is an insider, having been reared in the village. In relation to the villagers, he is an outsider having been to a university and learned the language of the outside society and of science. As a relative insider, he is aware that the outside researchers have misunderstood the villagers' motivations for their actions, but as a relative outsider, he cannot quite put his finger on the precise mistake in the researchers' misunderstandings of villagers' motivations. He no longer tacitly and fully appreciates villagers' linguistic and conceptual categories, although he understands them once they are invoked by the villagers', something beyond the grasp of the anthropologists (Bartunek and Louis, 1996, p. 12).

This analysis from Ryan's story can reiterate that membership to a group does not mean sameness and that not belonging to a group means difference. Therefore insider/ outsider research as a dichotomous identity system of study can be restrictive and simplistic (Dwyer and Buckle, 2009) and that these roles as insider or outsider can reside along a continuum rather than being purely insider or outsider completely.

Another viewpoint of insider/outsider research concepts is explored briefly by Smith (1999) explaining that researchers who identify as indigenous often find that their training guided primarily within western academy creates a disconnect. This disconnect is between the expectations of the institutions in which they study, and the indigenous analysis collected organically by simply being active within their own indigenous communities or from being raised within this. These different spaces are 
exemplified within previous study conducted on Ngāti Ruakā from hapū members (Tinirau, 2008; Tinirau et al, 2009).

Tinirau (2008, p. 296) reflects on the different spaces Ngāti Ruakā members can occupy as both cultural insiders and outsiders at different times and additionally, perspectives of what is seen as the most valuable from the research,

Although this process was steered by mokopuna trained in western systems of knowledge, retaining and subscribing to Māori ways of knowing and preferences for knowledge acquisition and sharing were paramount. Such practices from a western perspective infer a range of preconceptions that are said to distort or contaminate the data collected — making the findings less valuable—yet from a Māori perspective the opposite is true. Protection, respect for participants, richness of data and researcher privilege were found to be of more importance and value.

The idea of data contamination and distortion (Tinirau, 2008) can allude to the value of oral history used by Māori for retaining information as having revealing qualities, such as being able to potentially provide "direct information from and about groups whose written history may be missing or distorted" (Mahuika, 2009, p. 95).

These discussions bring into question the indigenous researchers ability to remain objective from their own communities and the discoveries made from the research. Studies within this area have revealed that the notion of 'objectivity' is illusionary, as guiding worldviews will always be a contributing factor, as researchers will tend to utilise research methods that favour their overall worldview (Allen and Montell 1981; Ka'ai Mahuta, 2010; Jackson, 1988). 
This reflection also intersects with broader ideas surrounding indigenous researchers who occupy different spaces, which can inform the simultaneous standpoints of being cultural insiders within the context of their institutions or research model as well as outsiders, due to being representative of a marginalised or minority group. Parts of these simultaneous standpoints also align with the viewpoints of Bartunek and Louis (1996), however they also state the importance of setting in relation to insider and outsider roles. These positions have been referred to as 'the outsider within' and provide an alternative stance on what is usually seen as a binary dichotomy between insider/outsider research (Hill, 1991).

\section{Summary}

The literature review has two parts and examines waiata study within Aotearoa and interdisciplinary methodologies, methods and frameworks. The first part of the literature review primarily explored the study of waiata within the context of Aotearoa through early works, Ngā Mōteatea as well as international archival preservation methods. These included waiata genre categorisations, transcription, as well as copyright and intellectual property. The second part of the literature examined the ways in which oral history methodologies are not used in Aotearoa; how phenomenology can be valuable within articulating performance experience; and lastly, the position of the researcher within ethnomusicological and insider/outsider methods. 


\section{Chapter 3.}

\section{Methodologies}

Kataraina Millin: I was just thinking of our men who learn the taiaha now. They don't always come home now. Once upon a time you went home to learn those things.

Josephine Takarangi-Firmin: But you went home to get permission as well. You went home to your kaumātua and they will tell you when you're ready; not when I'm ready... and whether you deserve it...

Tamihana Puketapu: And the thing is that, you say a... self-imposed mana on themselves? (Focus group, interview, 2 April 2017).

\section{Introduction}

As the above interview excerpt demonstrates, Ngāti Ruakā follow the decisionmaking process of going back to the ahi kā, both as reconnecting to the ancestral land base (place) as well as seeking permission from the occupying caretakers of knowledge and the marae (role). The hapū also follow tikanga Whanganui for their overall ethical process (Tinirau et al, 2009; Tinirau, 2008). The aim of this chapter is to examine the ethical and methodological framework of this research, which places Ngāti Ruakā perspectives and lived experiences regarding waiata preservation (kaiponu) as central.

This research uses a Kaupapa Māori approach as the overarching methodological framework alongside music performance methods and thematic analysis to explore hapū participant views. This section will explore three primary components regarding the ethical and methodological framework and these will be explained further in turn. 
The first section will examine the ethical framework for this research, which is tikanga Whanganui and this is an essential aspect for Ngāti Ruakā regarding hapū knowledge. While it can be considered unorthodox within a traditional thesis structure to initially engage the ethical framework, for Ngāti Ruakā this is central to the research. This research is also collaborative and the ethical framework consists of Whanganui identity. The second section will examine the overarching methodological framework of Kaupapa Māori research and how this will intersect with various aspects of tikanga Whanganui. The third and final section will discuss music performance methods in relation to the preservation and kaiponu of Ngāti Ruakā waiata as well as tikanga Whanganui. This section aims to give context surrounding the use of tikanga Whanganui, Kaupapa Māori and music performance methodologies to specify further justifications in studying with Ngāti Ruakā.

\section{Section 11: Tikanga Whanganui}

Tikanga Whanganui is situated within the locale of Whanganui and encompasses the practices of Whanganui specific protocols, customs and ground rules when working collaboratively with hapū koroheke and kuia as well as other members. These include but are not limited too, distinctly Whanganui karakia, kupu (words) or phrases unique to te mita o Whanganui (the dialect of Whanganui), which are practised and referred too during discussions with kuia and koroheke. Encircling these specific aspects of tikanga Whanganui are Whanganui specific whakapapa, whakawhanaungatanga, wānanga, the mita as well as the whenua. Amongst these aspects of tikanga Whanganui that are imbued with Māori identity markers, the researcher having whakapapa and whakawhanaungatanga to the hapū are essential components in gaining access to the hapū community and body of knowledge (Tinirau, 2008). 
The concepts surrounding tikanga Whanganui are intrinsic to the ethics of the study because I am a member of the hapū through both whakapapa and whakawhanaungatanga as their mokopuna. My affiliation creates a collaborative research venture between hapū and mokopuna, a type of researcher privilege, a necessity in being respectful as well as being protective of hapū knowledge that would not generally be accessible for other members who are a part of the iwi, but not of the hapū, even if they are Māori (Gillies et al, 2007). There also exists fears and caution surrounding western research, as previous research has been conducted on kuia and koroheke in the past, which has disrupted Māori cultural norms of whānau and whakawhanaungatanga by interference and invasive ways (Bishop, 1998, 2005; Gillies et al., 2007; Smith, 1999).

Moreover, this research proceeded with the protection of the hapū community as paramount. Kuia, koroheke and tūpuna have been subjected to negative past experiences with western academic practices and therefore, great caution and awareness of this was important. However with this awareness of the past in mind, kuia and koroheke see potential and the value of this type of research for future hapū descendants and the ways in which this research can be a tribute to the past. They support their mokopuna (myself) leading the research but with kuia and koroheke of Ngāti Ruakā (the Rānana Māori Committee) controlling the research through joint collaboration and ongoing consultation.

As a member of Ngāti Ruakā (mokopuna) steering this research, the study uses tikanga Whanganui as the ethical framework, as the hapu ancestral land base is situated within Whanganui. This framework is used to provide the particular spiritual 
guide, protocol and rules that are essentially Whanganuitanga. Tikanga Whanganui also provided a better sense of organisational flow for the semi-structured nature of the focus group (hui) interview, as each process is uniquely Whanganui specific: the karakia that opens and closes the interview originates from Whanganui, instances where participants draw on te mita o Whanganui as well as speak te reo Māori and kupu of Whanganui specific dialect throughout the interview process. Te mita o Whanganui (te reo dialect) in particular involves a distinctive glottal form concerning the ' $h$ ', especially with regard to the digraph 'Wh' where the ' $h$ ' is omitted from the vocalisation of words involving this digraph. Whanganui dialect also includes different words, phrases, sentence structures, pace and rhythm (Wilson, 2007).

\section{Section 12: Kaupapa Māori}

Kaupapa Māori is centred on philosophies of mātauranga Māori and with a "metaphysical base that is distinctly Māori” (Smith et al, 2000, p. 3). Additionally, Kaupapa Māori influences the way in which Māori think, understand, interact and interpret the world while having inextricable links to te reo Māori (te reo Māori me ōna tikanga) as a type of access point to conceptualise and internalise a Māori body of knowledge (Nepe, 1991).

Smith's (1997) pivotal work concerning the use of Kaupapa Māori in the education field discusses three key themes. These key themes are also relevant for the field of waiata study, as waiata (waiata tawhito or mōteatea) is primarily composed and written in te reo Māori. The key themes are:

1. The legitimacy and validity of Māori are taken for granted

2. The revival and survival of te reo Māori is vitally important 
3. The autonomic agency over the cultural wellbeing and lives of Māori is crucial to Māori struggle

Te reo Māori me ōna tikanga again plays a very significant role within these themes as an essential reproduction of Kaupapa Māori (Nepe, 1991).

Smith (1997) further highlights six integral intervention elements that are also evident within Kaupapa Māori sites. These six elements are expanded upon through the different works of Smith (1999) and Tūpara (2009) within their respected disciplines of indigenous education as well as public health. These six elements exemplify Māori language, culture, worldviews and philosophy:

1. Tino rangatiratanga: self determination

2. Taonga tuku iho: cultural aspirations

3. Ako Māori: culturally preferred pedagogy

4. Kia piki ake i ngā raruraru o te kāinga: socio economic mediation

5. Whānau: extended family structure

6. Kaupapa: collective philosophy

Along with these six elements, a Kaupapa Māori approach is used in this study to ground the research within a Māori perspective as well as a Ngāti Ruakā perspective as both Māori and Ngāti Ruakā meanings, understandings and knowledge are crucial (Tūpara, 2009).

Tūpara (2009) explores different sects of the Kaupapa Māori approach as well as other independent Māori-based frameworks, which she refers to as 'research strategies' and some of these are undergoing development. These research strategies are explored against their historical contexts within academia and how they can be 
used in conjunction with the Kaupapa Māori approach, as there are overlapping implications. These overlaps are used to create secure connections between whānau and her study, as well as employing better avenues for expressing their lived experiences. Tūpara (2009) discusses a large range of these specific research strategies, however these strategies are guided towards her respected discipline of public health. For example, these include strategies surrounding holistic personal well-being, such as hauora. Due to these reasons, these strategies may not contain explicit relevancy for its application in ethnomusicology and more specifically, waiata study and therefore have not been considered for this research.

\section{Whakawhanaungatanga}

This research strategy originates from Kaupapa Māori but focuses on the relationship of both researcher and participants more closely as collaborative work and with the ultimate goal of shared insight and discovery. Bishop (1996) argues that the onus of control rests solely with the participants and that the researcher only facilitates the collaborative journey. Moreover, these roles help to modify the power dynamic between both parties.

Whakawhanaungatanga and Kaupapa Māori overlap in three ways, which firstly include the formation and maintenance of relationships being fundamental and long term. The second overlap comes from the way in which researchers engage in the research with the participants through a variety of ways that do not exclude spiritual and moral processes. The third and final overlap reiterates participant-driven research as well as shared approaches to research (Bishop, 1998). 
Whakawhanaungatanga also recognises the personal nature between the researcher and the researched through the relationships shared by whakapapa (Tūpara, 2009). This is crucial as I am a member of Ngāti Ruakā and this research strategy can help navigate shared ancestral history within the context of waiata or oral hapū taonga.

\section{Te Ao Mārama}

This research strategy is referred to as Te Ao Mārama by Royal (1998) as well as Tūpara (2009) and is a separate framework from that of Kaupapa Māori. This framework is currently undergoing development. Te Ao Mārama examines the nature of origin through drawing on whakapapa to focus on the relationships between phenomena and trends. Whakapapa is not the entitling name for this framework despite whakapapa being used as a key analytical apparatus for whānau in this framework. This is due to Te Ao Mārama attempting to examine beyond the realm prior to whakapapa and is termed in this way to cater for diversity. This recognition in diversity allows for whānau to draw on their own resources and particular whakapapa to assist in effectively communicating their own unique experiences (Royal, 1998).

This research strategy is fundamental within the collaborative work of exploring the ethics of kaiponu as a preservation methodology and framework in regards to Ngāti Ruakā waiata or oral taonga. Te Ao Mārama and its use of whakapapa as a type of historical account calls on stories of origin and is used to pass down knowledge as well as uncover answers, solutions and wisdom from past events, deeds and accounts of tūpuna (Tūpara, 2009). The act of drawing on ancestral links can inform different processes of waiata study, preservation and transmission. 
The term kawa is discussed among different iwi in regards to its meaning and difference from tikanga Māori. Some iwi groups refer to kawa as the knowledge base and tikanga as the practice of that knowledge. For other iwi groups this position is the reverse of this (Mead, 2003). It is important that this discussion of meanings be acknowledged, as the Ngāti Ruakā position on this debate is pivotal in further understandings between theoretical knowledge and the practicality of this through protocol. For Whanganui, kawa are permanent values.

Kawa is also known for its relation to marae protocol either referring to pōwhiri or for Whanganui this refers to whakaeke. ${ }^{9}$ On a broader level yet built from this, kawa is a framework centred on Māori ethical practice that is underpinned by philosophical values within the Kaupapa Māori approach. However as a research strategy, the symbolism of kawa demonstrated within the whakaeke process is key to its application as a research strategy.

A brief overview of the whakaeke or the ceremony of welcome onto the marae consists of the following process: the karanga (call onto the marae/pōwhiri), the response to the karanga by the manuhiri (visiting group), an exchange of greetings, the kaikōrero (orators) by both hosts and visitors and lastly waiata, which follows after each orator to consolidate their kaikōrero. It is within this process, particularly within the kaikōrero and waiata sections where whakapapa connections are reinforced from each party and are thereafter embellished by song (Tūpara, 2009; Mead, 2003). These whakapapa connections initiated by the orators also intersects with whakawhanaungatanga, where the relationship between both parties is discussed

\footnotetext{
${ }^{9}$ For Whanganui, pōwhiri refers to the karanga (call onto the marae) and whakaeke refers to the marae protocol and process.
} 
amongst both of their common areas of interest or conflicts of difference. Drawing these connections of whakapapa as well as the intricate realities of both parties requires proficiency in te reo Māori and the pōwhiri process, as one of the main objectives of this ceremony is to gain consensus as well as a better understandings of each other (Tūpara, 2009). The whakaeke process and kawa symbolises the contribution towards the overall kaupapa by both the researcher and the hapū.

\section{Mātauranga}

This research strategy highlights the challenges of applying a contemporary lens to early ways of thinking and draws on Māori intellectual systems (Royal, 2003; Tūpara, 2009). Royal (2003, p. 33) discusses the origin of mātauranga within Kaupapa Māori, The phrase mātauranga Māori does not refer explicitly to any particular kind of methodology or a set of explicit actions and goals, as is the case with kaupapa Māori theory. Rather, mātauranga Māori is a modern phrase used to refer to a body or a continuum of knowledge with Polynesian origins, which survives to the present day albeit in fragmentary form.

Royal (2003, p. 33-34) then goes to state that,

Mātauranga Māori, on the other hand, is used merely to label a body of knowledge. It does not tell us what we might do with this body of knowledge, rather it 'frames' knowledge in certain ways.

This body or continuum of knowledge, which is also referred to as Māori intellectual systems (Tūpara, 2009) draws on early Māori epistemologies and frames of knowledge for this research both within the context of Kaupapa Māori and within the contemporary realties of Ngāti Ruakā.

In terms of specific bodies of knowledge or Māori intellectual systems that is used within the research, there are two systems and these include, whakataukī as well as 
kōrero pūrākau. These systems are used within the research to help Ngāti Ruakā and myself articulate the changing viewpoints and purposes of waiata, its study as well as its preservation within kaiponu. These two systems will be briefly explored below in more specific detail and how it relates to helping Ngāti Ruakā perspectives.

\section{Whakataukī and kōrero pūrākau}

Both whakataukī and kōrero pūrākau are performative parts of oral history and they both support the maintenance of whakapapa through conveying philosophical ideas. Whakatauki relies on the medium of proverbial sayings as a way of imparting knowledge and kōrero pūrākau refers to the act of story telling as the primary way of communicating iwi, hapū and whānau knowledge. Both of these mediums of knowledge transmission contain layers of meaning and therefore can impart many interpretations, however the primary goal of this is to express the embedded lessons within (Tau, 2003; Jones, 1965). The use of these two mediums helps to centre and ground the ideas of Ngāti Ruakā by drawing on past narratives and proverbs that elude to wider philosophical understandings surrounding particular issues regarding waiata within a contemporary context.

\section{Section 13: Music performance methods}

Holmes and Holmes (2012) examine the subjective processes of a performer by stressing the importance of participatory aspects (having to experience, learn, practice, perform and understand music) but solely within a qualitative context. This music performance method aims to use smaller components of phenomenological approaches to illuminate experience and different kinds of meaning within the context of the participants' perspectives. This particular music performance method is 
explored in relation to its application to Ngāti Ruakā, tikanga Whanganui as well as the wider methodological framework of Kaupapa Māori.

The use of phenomenological informed methods as smaller components within a larger methodology and framework help in providing a sense of meaning (Holmes and Holmes, 2012, p. 80 as cited in Smith and Osborn, 2008):

This is integral to the recognition that meaning is the central focus of the analysis; the researcher needs to 'understand the content and complexity of those meanings rather than measure their frequency.'

This is the basis of their belief in terms of using technology and electronic software (audio recordings or numerical based technologies of recording music); and that it is crucial that these methods do not inhibit examining the meaning within the performance experience (Holmes and Holmes, 2012; Smith and Osborn, 2008).

Semi-structured and conversation-styled interview processes are key to Holmes and Holmes (2012) music performance method. This is regarded as the "most natural medium of communication" and allows for "both structure and flexibility and allows a depth of response that can reflect the multi-layered thought processes that necessarily precede action" (Holmes and Holmes, 2012, p. 78).

This framework can be adapted to align with certain areas of Kaupapa Māori as well as tikanga Whanganui. Rather than examining the interpretation of a performace through an audience perspective, this music performance method can help to explore the meanings behind the performance through the views of the performer within the conversation style and semi-structured interview process (Holmes and Holmes, 2012; Jensen, 2015, 2016; Patton 2002). The central element of the interview process is 
capable of highlighting the lived experiences of Ngāti Ruakā and does not inhibit kupu or te mita o Whanganui, which corresponds with tikanga Whanganui. The lived experiences of the hapū is pivotal and significant in both Kaupapa Māori and music

performance methods through highlighting meanings within waiata learning, transmission, study and preservation through kaiponu (Smith et al, 2000; Holmes and Holmes, 2012; Jenson, 2015; 2016). This can be otherwise known as the informal kōrero within Kaupapa Māori (Smith et al, 2000).

\section{Summary}

This chapter looked at the ethical framework for this study, which is tikanga Whanganui as well as the methodological framework for this study. A Kaupapa Māori approach is the overall and guiding research tradition for this study as well as music performance methods and these are comprehensively explored. This chapter provided the rationale for collaboratively creating culturally appropriate hapū waiata methodologies (kaiponu) regarding preservation in relation to tikanga Whanganui. 


\section{Chapter 4.}

\section{The research process with Ngāti Ruakā}

\section{Introduction}

Bishop (1996) has stated the research on Māori as well as Māori lived experiences has been of more benefit to researchers, rather than the participants themselves. Therefore within the context of this thesis, Ngāti Ruakā hapū member perspectives are central, as this research is focused on hapu knowledge and it is vital that the research is beneficial for the wider hapū community. An approach that situates hapū member perspectives through the inclusion of specific hapu tikanga, culture, beliefs and values can reflect a particular set of Māori realities that can in turn provide positive outcomes for hapū members as well as the wider iwi and Māori community (BevanBrown, 1998).

This chapter outlines and examines the different phases of study surrounding the research process with Ngāti Ruakā hapū participants. This chapter will examine; collaborative consultation and participant recruitment; data collection, which will explore the use of semi-structured interview processes and introduce the participants within the focus group as well as the individual participant interviews; and lastly, data analysis, which uses thematic analysis.

\section{Section 14: Collaborative consultation and participant recruitment}

When I first began considering a thesis involving hapū, it seemed logical to me that reconnecting to those who I had not seen in years was important. This was due to living away from Whanganui when I was growing up in Palmerston North and during 
my undergraduate degree in Dunedin. The long distance from the hapū meant that a consolidated relationship on my part needed to be built again. I have whakapapa to Ngāti Ruakā on my Fathers' side as well as Eurasian multi-racial ethnicities from my Mothers' side that extends across the area of South Asia and South East Asia, as she is from Singapore. This study ${ }^{10}$ however, began more formally during May 2016 when I started enquiring.

As a child, my involvement on the marae and hapū community was set and I was comfortable, as I was involved in the Rānana marae and I knew my whānau members well. However, this became estranged as I grew up and moved away and in many ways this can be interpreted as a form of ahi tere ${ }^{11}$. The re-establishing of a relationship took place through kanohi kitea (seen face, or face-to-face interaction) by being physically involved and active within the Ngāti Ruakā community. This includes helping Ngāti Ruakā events (River Road Relay and Gala day as examples) as well as attending Rānana Māori Committee meetings that occur monthly every first Sunday to listen and observe decision-making processes of koroheke and kuia ${ }^{12}$ on matters affecting the hapū community.

\footnotetext{
10 The term 'study' pertains to the act of respectfully and ethically collecting and creating knowledge collaboratively with Ngāti Ruakā. The reason as to why this term calls for clarification is due to its undertones that are reminiscent of previous definitions deciding on what is collected, classified and representative of indigenous cultures as well as touching on ideas of primitivism. These meanings can allude to preceding traditionally ethnographic gazes stemming from anthropology and their denotation to the term 'study' (Smith, 1999). Smith (1999, p. 67) has continued to state that, “... anthropologists are often the academics popularly perceived by the indigenous world as the epitome of all that it is bad with academics" due to instances of exploitation from the generosity given by indigenous for allowing anthropologists to gain access and collect their knowledge. Therefore within the context of this research, the term 'study', which is used within the title of the project, is used to ascribe to a more ethically grounded approach of collaboratively collecting and creating knowledge with hapū, unlike some precursory definitions.

11 Ahi tere refers to an unstable fire through relocating away from the ancestral land base and can include marrying and having to move outside of one's tribal area (Tinirau et at, 2009).

12 The term 'kaumātua' within the context of te mita o Whanganui is originally a foreign term to Whanganui but it has been integrated within recent Ngāti Ruakā specific methodology research (Tinirau, 2008). Instead the terms 'koroheke' and 'kuia' are used interchangeably as they follow te mita o Whanganui as well. The more traditional term from Whanganui is 'pahake' and refers to the people who protect and uphold marae protocols of tikanga Whanganui. These include roles such as conducting paepae (threshold of the traditional meeting house), kaikaranga (women who perform the traditional welcoming call), kaikōrero (orators) and kaiwaiata (singers or
} 
The Rānana Māori Committee was vital for not only renewing my relationships with the hapū community I had not spoken with in a long time, but also to seek approval, permission and ongoing consultation throughout the study. The permission and consultation process was crucial in terms of conducting culturally appropriate methods of Whanganui kaiponu with the hapū of Ngāti Ruakā surrounding hapū knowledge, as it is their taonga. This consultation began on May 2016 by meeting with the Chair of the Rānana Māori Committee, Rāwiri Tinirau, to discuss the best ways for the Rānana Māori Committee, on the behalf of Ngāti Ruakā hapū, to support the research, as well as to outline my obligations ethically to the hapū.

As a result of this discussion, it was imperative that I present my study directly with Ngāti Ruakā at the next Rānana Māori Committee meeting with the support of my whānau. I presented my study on the $5^{\text {th }}$ of June 2016 at Rānana Marae with Ngāti Ruakā. Koroheke and kuia asked questions about the study, gave their consent as well as their permission for me to start conducting my research that would begin in September 2016 (See Appendix A: Section 1 for written statement of support). I also asked for support from the Rānana Māori Committee through acting as a consultation panel throughout my research, where I could enquire about tikanga, research ethics as well as specific hapū knowledge considered taonga every month during the marae committee meetings, to which they approved. The hapū of Ngāti Ruakā were very forthcoming and generous with their support for the study for which I am very honoured, privileged and thankful.

chanters). These roles are not restricted by age (Gillies et al, 2007; Tinirau et al, 2007; Tinirau, 2008). The term 'pahake' is acknowledged within this research to comply with tikanga Whanganui but the term 'kaumātua' is not used and instead 'koroheke' and 'kuia' are used to refer to the elders of Ngāti Ruakā. 
In all, a total of 12 participants from Ngāti Ruakā hapū took part in this study. There were two different formats used in terms of conducting interviews and these included a focus group interview (hui) and individual participant interviews. For both of these interview formats the same participant recruitment method was used and this was distributing participant information sheets (See Appendix A: Section 2) as well as consent forms (See Appendix A: Section 3). These sheets and forms were distributed during the Rānana Māori Committee meetings to hapū members who also gave these forms to their whānau members who they felt this study would be of interest. The Chair of the Committee advised that this would be the best method, as many koroheke and kuia did not use email or phones and that they would be the best people to relay information regarding my study to their whānau members.

In preparation for the hui (focus group interview), initially the participant information sheets and the attached consent forms were planned to be distributed out to hapu members on Sunday the $5^{\text {th }}$ of February, 2017 and for the focus group (hui) interview to occur the following month after the next Rānana Māori Committee meeting, which would have been Sunday the $5^{\text {th }}$ of March, 2017. However due to Waitangi weekend during February, which occurred around the originally scheduled meeting time of the Committee, this meant that hapū members were very busy. Therefore the Rānana Māori Committee was scheduled a week earlier (Sunday the $29^{\text {th }}$ of January, 2017) and I was not informed until after the meeting. This meant that both the distribution of participant information sheets and consent forms as well as the actual date for the focus group interview had to be moved a month later. The distribution of forms occurred on Sunday the $5^{\text {th }}$ of March, 2017 at the Rānana Māori Committee meeting and the focus group interview took place the following month after the same 
Committee meeting on Sunday the $2^{\text {nd }}$ of April, 2017. This took place at the Rānana Marae along the Whanganui awa. In total, 10 hapū members participated within this focus group interview.

In terms of the individual participant interviews, 2 individual hapū members were interviewed separately due to their schedules as well as personal opinions that they felt would be best articulated through this format. Both of these participants were informed through the ongoing consultation given during the Rānana Māori Committee meetings and were also given the necessary forms there. The first individual participant interview took place over two interviews due to the participant's scheduling. The first interview took place on Monday the $6^{\text {th }}$ of February, 2017 and the second was held on Monday the $20^{\text {th }}$ of March, 2017. Both of these interviews took place in their home. The second individual participant interview with the other hapū member took place on Wednesday the 19th of April 2017.

\section{Section 15: Data collection}

The data was collected through the use of semi-structured interviews in both the focus group and individual interview formats. All of the interview formats followed the same interview guide and questions, where some of these were initially close-ended questions but contained a second part, which then consisted of an open-ended question. These questions were also assisted and approved by the Chair of the Rānana Māori Committee before the interviews took place and during the consultation process. The consent forms for the interviews were collected after both the focus group interview as well as the individual participant interviews. All of these interviews were conducted kanohi-ki-te-kanohi where I came either to Rānana Marae 
to interview the focus group, as did some of the participants who do not live on the marae area or who live in Whanganui, otherwise I met the participants at their homes for the interviews. These interviews took place between February and April, 2017.

The use of the semi-structured interviews in conjunction with kanohi kitea consolidates the relationship with hapū (Smith, 1999; Mead, 2003) and can allow for flexibility and latitude to move from one context area to another and for the researcher to explore within predetermined inquiry areas (Loftland and Loftland, 1984). This ease in migrating between contexts also allows for the researcher to follow up on participant cues and to allow for a considerable amount of time on one subject or another (DiCicco-Bloom and Crabtree, 2006). There were particular subject areas that I wanted to explore in more detail and these included the ways in which vocality was approached and sung within certain waiata. This required that the interview structure could be adaptable in hearing and singing waiata, as these experiential responses within a semi-structured interview can reflect the multiple layers within performance thought processes that come before action (Holmes and Holmes, 2012).

For the focus group interview there was a moderator present who intermarried into the hapū, has two children who belong to the hapū and she is my Mother. She had conducted collaborative research previously with Māori (Fernandez, 2015) exploring Māori models for health service delivery and the hapū and I felt that this academic research background would be beneficial for the study. She also has a strong relationship with members of the hapū, especially my Nanny and we all wanted her to be part of the study in some way. The moderator helped to shift the interview back to 
the questions if the subject matter was digressing or if other hapū members had not been given a chance to speak. I found having a moderator helpful, as it gave another perspective to observe the focus group through a wider lens, as I was concentrating on interviewing, listening and asking the questions. The moderator was chosen collaboratively between the hapū and I throughout the consultation process in previous Rānana Māori Committee meetings. The moderator only prompted me once to let one particular hapū member speak, who had not been given a chance to speak during the focus group interview up until that point.

All the hapū participants chose to be identified (See Appendix A: Section 4). Ngāti Ruakā wanted to be identified because the subsequent transcripts would indicate to the wider hapū who participated and how their views informed the study. An additional reason was that this study has potential for future use for the participants' descendants and whānau members. They wanted to inform their descendants about their views surrounding hapū waiata knowledge. This reason in particular is meaningful in the way of its legacy and it is a privilege on my part to contribute in this way for present and future hapū members. Due to these reasons, the hapū members preferred to be identified within this study and they will be listed below (See Figure 4). 
Focus group (hui) interview Sunday the $2^{\text {nd }}$ of April, 2017

1. Kataraina Millin

6. Toreheikura Puketapu

2. Christina Tapa

7. Angeline Ann Haami

3. Josephine

8. Bernadette Hadfield

Takarangi-Firmin

9. Evelyn Broad

4. Peter Broad

10. Tumanako Haami

5. Tamihana Puketapu

\section{Individual participant interviews}

1. Pita Haami (Held on Monday $6^{\text {th }}$ of February, 2017 and Monday the $20^{\text {th }}$ of March, 2017).

2. Rāwiri Tinirau (Held on Wednesday $19^{\text {th }}$ of April, 2017).

The interviews opened and closed with a karakia and a waiata. Hapū members and myself also provided kai before the interviews as apart of the Rānana Māori Committee that had taken place previously. Koha was given to the Rānana Māori Committee as a monetary donation from myself as well as small chocolates and these were given to all of the participants individually after the interview.

\section{Section 16: Data analysis}

Thematic analysis was conducted on the data ${ }^{13}$ obtained from findings and these were collected from interviews with participants. Thematic analysis can assist to develop and sense codes in interpreting the information and overall themes of the data (Boyatzis, 1998). The researcher must look at how "a theme captures something important about the data in relation to the research question and presents some level of patterned response or meaning within the data set" (Braun and Clarke, 2006, p. 77).

\footnotetext{
13 The term 'data' in terms of waiata, can allude to numerical based ways of processing music, as waiata, talking about waiata, its transferability into data as well as the term itself is an aspect that may prove problematic and not the most appropriate term. However this term has been used within the context of this research to attribute towards the various views, opinions and beliefs of hapū participants regarding waiata hapū knowledge.
} 
The recognition of patterns from within the data can give rise to areas for further analysis, which derive from emerging themes (Fereday and Muir-Cochrane, 2006). The use of thematic analysis arranges the wider and sometimes varying experiences and realities felt within the hapū in terms of waiata knowledge, oral hapū taonga as well as the adaption of Whanganui kaiponu within preservation contexts, which coincides with the fluidity of the semi-structured interviewing process.

Thematic analysis was conducted within this study by adapting Boyaztis (1998) plan and this consisted of teasing out themes, producing codes as well as interpreting the information. Boyatzis (1998) highlighted two approaches in which themes could be identified and these included an inductive or a theoretical approach and both these ways map how and why the data is coded. For this study, theoretical thematic analysis was used, as it provided a more detailed analysis of certain aspects of the data and allowed for the coding of specific research questions (Braun and Clarke, 2006). The research concentrated on how culturally appropriate methods of preserving waiata through Whanganui kaiponu was evident across the data, resulting in a number of themes around participant views on current preservation methods of waiata hapū knowledge.

An additional decision regarding the use of thematic analysis encompassed the 'level' at which the themes were to be identified and Boyatzis (1998) describes these two levels as a semantic or latent level. This study used a semantic level approach, which allowed for the themes to be identified within the precise meanings of the data and allows for the researcher to not look for anything beyond what was said by each participant (Braun and Clarke, 2006). 
The process of analysis at a semantic level began from description where the data was organised to show semantic content and then summarised to interpretation (Patton, 1990). These patterns were then theorised in terms of their significance, their broader meanings as well as their implications in relation to previous literature (Frith and Gleeson, 2004). This process of analysis has been used to avoid a sense of 'projection,' which has been highlighted by Boyatzis (1998, p. 13) as an analytical flaw stating, "with ambiguous qualitative information there is more likelihood for projection from the researcher than in most types of other research." This approach also coincides with Kaupapa Māori methodologies, in terms of allowing for Māori realities and voices to be central (Smith et al, 2000; Tūpara, 2009). Within the context of this study, allowing for Ngāti Ruakā perspectives to be heard regarding hapū waiata knowledge and oral hapū taonga is paramount. These reasons additionally contribute to why this particular approach was chosen within the beginning stages of the study.

The process of theoretical thematic analysis through a semantic level began by creating a preliminary table (Table 5) of codes and themes and this was based from the interview questions and guide. This allowed for the process of reading the raw data easier to analyse. The raw data was analysed a few times to gain familiarity with the content and better understanding of the text. The passages from the text were examined for meaning to identify patterns and these were then coded. Boyatzis (1998, p. 22) describes this process of coding, "recognising (or seeing) an important moment and encoding it (seeing it as something) prior to a process of interpretation." The data was then organised and allowed themes to be identified. 
This process of analysis resulted in two tables. The first was the preliminary table (See Table 5) which demonstrates how Boyatzis's (1998, p. 66) plan to develop initial codes and themes was adapted revolving around the interview questions and guide. The second table is the final table (See Table 6) and this shows how the initial themes were connected to hapū participant views on culturally appropriate methods regarding hapū waiata knowledge and preservation according to Whanganui kaiponu.

The preliminary table (See Table 5) will be explained further in turn. The first column called the 'phenomena of interest' relates to the core inquiry areas regarding the interview questions guide. The second column called the 'unit of analysis' typifies these phenomena in regards to its most pertinent perspective. The third column of 'code' shows the wider subject areas that the phenomena and perspectives of the participants intersects with and conveys the participant understanding of specific thought and interconnected processes. The fourth and final column examines the 'initial themes' brought about through the inquiry of the phenomena, the participant perspectives and also the participants understanding of their own perspectives in relation to the phenomena. These initial themes serve as different pools of how the different intersections and subject areas of hapū based methodologies in relation to waiata can be filtered and examined.

The final table (See Table 6) will be explored further in turn. The final table connects the initial themes of the preliminary table to participant views on waiata hapū methods of preservation surrounding Whanganui kaiponu for Ngāti Ruakā. The first column called the 'initial themes' illustrates the same initial themes brought over from the preliminary table and lists the same themes being examined. The second 
column called 'focus of research data' examines the participant views brought about through initial themes. The third and final column named 'summary of views on relevant waiata hapū methods of preservation for Ngāti Ruakā' outlines the overarching views that were highlighted as being very important from the various views that were discussed from the initial themes and from the focus of research data columns. These condensed views will serve as the aspects for further discussion. The final table is displayed after the preliminary table (See Table 5 and 6). 


\begin{tabular}{|c|c|c|c|}
\hline Phenomena of Interest & Unit of analysis & Code & Initial Themes \\
\hline The meaning of waiata & Hapū perspectives & An understanding of waiata discourse & $\begin{array}{l}\text { Waiata from a Ngāti Ruakā perspective } \\
\text { (The change and/or fixed meanings and } \\
\text { perspectives of waiata) }\end{array}$ \\
\hline The idea of 'preservation' & Hapū perspectives & $\begin{array}{l}\text { An understanding of impacts and influence of } \\
\text { terms }\end{array}$ & $\begin{array}{l}\text { Preservation from a Ngāti Ruakā } \\
\text { perspective (The ethical use of that term and } \\
\text { its philosophical underpinnings) }\end{array}$ \\
\hline $\begin{array}{l}\text { Waiata study surrounding cultural insiders } \\
\text { and outsiders as well as oral to oral } \\
\text { transmission comparative to notation } \\
\text { transcription }\end{array}$ & $\begin{array}{l}\text { Hapū perspectives and waiata, ethics and } \\
\text { methodologies }\end{array}$ & $\begin{array}{l}\text { Challenges within waiata discourse and } \\
\text { creating culturally ethical methodologies as } \\
\text { well as an understanding of previous waiata } \\
\text { methodologies used }\end{array}$ & $\begin{array}{l}\text { Challenges within waiata discourse } \\
\text { (Obstacles from previous waiata studies and } \\
\text { methodologies needed to be deconstructed } \\
\text { and critiqued) }\end{array}$ \\
\hline $\begin{array}{l}\text { Potential incorporation of digital technology } \\
\text { in waiata study, learning and 'preservation' }\end{array}$ & $\begin{array}{l}\text { Hapū perspectives and waiata ethics, } \\
\text { methodologies and practices }\end{array}$ & $\begin{array}{l}\text { Changes in contemporary approaches and } \\
\text { practices to waiata methodologies }\end{array}$ & $\begin{array}{l}\text { The use of technology for waiata (The } \\
\text { usefulness of technological tools in } \\
\text { conjunction with Ngāti Ruakā principles and } \\
\text { values in action) }\end{array}$ \\
\hline Participatory aspects of waiata learning & $\begin{array}{l}\text { Hapū perspectives and waiata ethics, } \\
\text { methodologies and practices }\end{array}$ & $\begin{array}{l}\text { Value of specific practices within waiata } \\
\text { methodologies }\end{array}$ & $\begin{array}{l}\text { The importance of participating and } \\
\text { experiencing waiata (sustaining waiata as a } \\
\text { living practice) }\end{array}$ \\
\hline $\begin{array}{l}\text { Genre-based approaches to waiata } \\
\text { categorization }\end{array}$ & $\begin{array}{l}\text { Hapū perspectives and waiata methodologies } \\
\text { and terms }\end{array}$ & $\begin{array}{l}\text { Value of specific processes within waiata } \\
\text { methodologies }\end{array}$ & $\begin{array}{l}\text { The categorization of waiata } \\
\text { (Deconstruction and critique of specific } \\
\text { approaches within previous waiata } \\
\text { methodologies) }\end{array}$ \\
\hline $\begin{array}{l}\text { Intersections between ahi kā and waiata } \\
\text { learning }\end{array}$ & $\begin{array}{l}\text { Hapū perspectives and waiata methodologies } \\
\text { and practices }\end{array}$ & $\begin{array}{l}\text { Challenges in connection to ancestral flame } \\
\text { and value of specific processes within waiata } \\
\text { methodologies }\end{array}$ & $\begin{array}{l}\text { The contemporary notions of ahi kā } \\
\text { (In relation to waiata learning and receiving } \\
\text { knowledge from the occupied land base as a } \\
\text { type of source) }\end{array}$ \\
\hline $\begin{array}{l}\text { Preferred methods of waiata learning, study } \\
\text { and 'preservation' }\end{array}$ & $\begin{array}{l}\text { Hapū perspectives and waiata ethics, } \\
\text { methodologies and practices }\end{array}$ & $\begin{array}{l}\text { An understanding of contemporary } \\
\text { approaches to waiata methodologies }\end{array}$ & $\begin{array}{l}\text { Ngāti Ruakā principles and values in } \\
\text { action (the interface between Ngāti Ruakā } \\
\text { principles/values and contemporary } \\
\text { approaches to waiata methodologies) }\end{array}$ \\
\hline
\end{tabular}

Table 5: The preliminary table been adapted from Boyatzis's (1998) plan to develop initial codes and themes in this research. 


\begin{tabular}{|c|c|c|}
\hline Initial themes & Focus of research data & $\begin{array}{c}\text { Summary of views on relevant } \\
\text { waiata hapū methods of } \\
\text { preservation for Ngāti Ruakā }\end{array}$ \\
\hline $\begin{array}{l}\text { Waiata from a Ngāti Ruakā } \\
\text { perspective } \\
\text { (The change and/or current } \\
\text { meanings and perspectives of } \\
\text { waiata) }\end{array}$ & $\begin{array}{l}\text { 1. Representation of whakapapa, ahi kā, tūrangawaewae } \\
\text { 2. Represents narratives and stories of events and origins of tūpuna as well as their environments that shaped their } \\
\text { compositions (i.e. birds and the awa) } \\
\text { 3. Body of knowledge (i.e. events, effects of time, reasons to its composition and kaupapa of waiata) } \\
\text { 4. Medium for Whanganuitanga and spiritual aspects of Whanganui (i.e. karakia) } \\
\text { 5. Connects to wairuatanga and spirituality } \\
\text { 6. Changed in meaning due to te reo Māori neologism } \\
\text { 7. A journey of deeper meaning } \\
\text { 8. Representation of composers mana and origination } \\
\text { 9. Te reo Māori changing for koroheke and kuia and thus affecting waiata composition }\end{array}$ & $\begin{array}{l}\text { 1. Waiata from Ngāti Ruakā is } \\
\text { hapū knowledge and oral } \\
\text { taonga representing } \\
\text { whakapapa, a kaupapa and } \\
\text { stories of tūpuna, } \\
\text { tūrangawaewae, ahikā, } \\
\text { tikanga Whanganui, } \\
\text { wairuatanga and a body of } \\
\text { knowledge } \\
\text { W. Waiata has changed due to te } \\
\text { reo Māori language evolving } \\
\text { (e.g. Waiata being a new term } \\
\text { for older generation) and } \\
\text { effecting composition, } \\
\text { understanding and } \\
\text { translations }\end{array}$ \\
\hline $\begin{array}{l}\text { Preservation from a Ngāti } \\
\text { Ruakā perspective (The } \\
\text { ethical use of that term and its } \\
\text { philosophical underpinnings) }\end{array}$ & $\begin{array}{l}\text { 1. Kaiponu as protection } \\
\text { 2. Hui Aranga and wānanga (not in the tertiary sense) as sites of preservation and transmission on the Whanganui awa } \\
\text { a. Taura Here wānanga } \\
\text { b. Natural affinity for waiata instilled by kuia and koroheke } \\
\text { c. Hui Aranga and waiata as a whakapapa legacy } \\
\text { 3. 'Preservation' in an academic context being clinical, museum like and archival }\end{array}$ & $\begin{array}{l}\text { 1. Term is "kaiponu" for } \\
\text { framework Ngāti Ruakā uses } \\
\text { for hapū taonga protections, } \\
\text { preservation and transmission }\end{array}$ \\
\hline $\begin{array}{l}\text { Challenges within waiata } \\
\text { discourse } \\
\text { (Obstacles from previous } \\
\text { waiata studies and } \\
\text { methodologies needed to be } \\
\text { deconstructed and critiqued) }\end{array}$ & $\begin{array}{l}\text { 1. Global influences and distractions } \\
\text { a. Te reo Māori changing and influence of western tonality } \\
\text { 2. Intentions and ethics of the person studying waiata are important } \\
\text { a. Permission and ongoing consultation with iwi, hapū and whānau with which the waiata concerns } \\
\text { b. Whakapapa for hapū members/cultural outsiders of 'why' they are studying hapu waiata } \\
\text { c. Non-Māori through intermarriage of previous ahi tere can provide a new perspective on hapu issues } \\
\text { d. The modern day has taken over } \\
\text { 3. Transcription } \\
\text { a. Helpful as "sometimes all we're left with are words" and figuring out the rangi } \\
\text { b. Important that te reo Māori to English translations are correct } \\
\text { c. Transcriptions are not the most suitable source of spiritual connection }\end{array}$ & $\begin{array}{l}\text { 1. } \begin{array}{l}\text { Ethics and intentions of } \\
\text { researcher are paramount } \\
\text { regardless of the background } \\
\text { of the researcher }\end{array} \\
\text { 2. } \begin{array}{l}\text { Global influences of western } \\
\text { music, tonality and virality }\end{array} \\
\text { (through the internet) } \\
\text { 3. Transcription methods are } \\
\text { nuanced within its outcomes }\end{array}$ \\
\hline
\end{tabular}




\begin{tabular}{|c|c|c|}
\hline $\begin{array}{l}\text { The use of technology for } \\
\text { waiata (The usefulness of } \\
\text { technological tools in } \\
\text { conjunction with Ngāti Ruakā } \\
\text { principles and values in action) }\end{array}$ & $\begin{array}{l}\text { 1. Audio technology } \\
\text { a. Beneficial as the rangi is figured out and for tools within educational purposes (i.e. Waka Huia) } \\
\text { b. Caution and use as a tool but not the entire framework ("Not the answer... they're just a tool") } \\
\text { c. Cannot capture the emotion behind the waiata } \\
\text { 2. Inevitability of digitalisation taking over } \\
\text { a. Proper safeguards in place } \\
\text { 3. Tūpuna being very adaptable in the past }\end{array}$ & $\begin{array}{l}\text { 1. Technology and digitalisation } \\
\text { can be beneficial as smaller } \\
\text { tool that can be used within } \\
\text { the wider framework but } \\
\text { should not be the entire } \\
\text { framework itself }\end{array}$ \\
\hline $\begin{array}{l}\text { The importance of } \\
\text { participating and } \\
\text { experiencing waiata } \\
\text { (sustaining waiata as a living } \\
\text { practice) }\end{array}$ & $\begin{array}{l}\text { 1. Participatory as oral } \\
\text { a. Waiata learning came from the 'head' and the 'heart' and was not written down } \\
\text { b. Learning waiata through repetition, listening and oral to oral transmission } \\
\text { c. "Soak it in... you catch it... oral; it's oral and you catch it?" } \\
\text { 2. Channelling experiences of the old people } \\
\text { a. "Creating a picture even if we don't know" } \\
\text { b. Importance of performers having a personal connection to the waiata and an in-depth understanding of it } \\
\text { 3. Music needs to be performed } \\
\text { a. "When you're in that moment" } \\
\text { 4. The bond that you create (relationships with other performers or your tutor) }\end{array}$ & $\begin{array}{l}\text { 1. Oral learning of listening and } \\
\text { absorbing important to } \\
\text { participatory and experiential } \\
\text { learning processes of waiata }\end{array}$ \\
\hline $\begin{array}{l}\text { The categorisation of waiata } \\
\text { (Deconstruction and critique of } \\
\text { specific approaches within } \\
\text { previous waiata methodologies) }\end{array}$ & $\begin{array}{l}\text { 1. Changed in the way of categorisations for koroheke and kuia } \\
\text { a. 'Waiata' as a new term and thought more as pao and karakia and that waiata now is more pātere for } \\
\text { b. Men sung pātere and women sung karanga (Pōhiri) } \\
\text { 2. Waiata had no categorizations but were used circumstantially within different situations } \\
\text { a. We used words to describe something rather than what they are now... rather than giving it a name" } \\
\text { b. Sung with "the air of the words" and importance of the beat to distinguish waiata } \\
\text { c. Importance of breath control and vocality } \\
\text { d. Waiata can have more than one classification } \\
\text { e. "Too unstructured... Western academia does not like that" and related to pōwhiri process } \\
\text { 3. Waiata seen as taonga } \\
\text { 4. Changes in waiata over time through traditional and contemporary spaces } \\
\text { a. Can evoke "self imposed mana" (change in Kapa Haka performance spaces) }\end{array}$ & $\begin{array}{l}\text { 1. The approach in vocality, } \\
\text { breath control and } \\
\text { articulation of words are key } \\
\text { indicators of what kind of } \\
\text { waiata is being sung } \\
\text { 2. Waiata has the ability to cross } \\
\text { genre classifications and is } \\
\text { never one or other, rather it is } \\
\text { dependent on the situation in } \\
\text { which it is sung }\end{array}$ \\
\hline
\end{tabular}




\begin{tabular}{|c|c|c|}
\hline $\begin{array}{l}\text { The contemporary notions of } \\
\text { ahi kā } \\
\text { (In relation to waiata learning } \\
\text { and receiving knowledge from } \\
\text { the occupied land base as a type } \\
\text { of source) }\end{array}$ & $\begin{array}{l}\text { 1. Ahi kā (place) } \\
\text { a. Source of hapū waiata and its knowledge } \\
\text { b. The environment as a site of origin and influence for composition (i.e. the maunga, awa, the birds) } \\
\text { c. Outside learning as a type of diaspora of hapū culture and knowledge } \\
\text { d. Broad hapū waiata knowledge taught in urban cities during schooling as a site of learning } \\
\text { 2. Ahi kā (role) } \\
\text { a. Wānanga of old people coming from Whanganui rural areas to urban cities to teach tamariki and rangatahi } \\
\text { b. "Coming home" is important to learn hapū knowledge as it belongs at home with ahi kā }\end{array}$ & 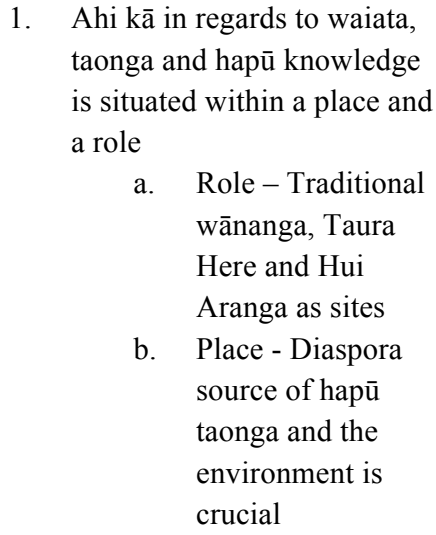 \\
\hline $\begin{array}{l}\text { Ngāti Ruakā principles and } \\
\text { values in action (the interface } \\
\text { between Ngāti Ruakā } \\
\text { principles/values and } \\
\text { contemporary approaches to } \\
\text { waiata methodologies) }\end{array}$ & $\begin{array}{l}\text { 1. Waiata as taonga and represents the hapū identity } \\
\text { 2. Kaiponu and sites of preservation important } \\
\text { a. Hui Aranga, traditional wānanga and Taura Here also representative of ahikā notions } \\
\text { 3. Ethical process, intentions and kaupapa of the person studying waiata are important to establish } \\
\text { a. Whakapapa for hapū members and ethical considerations for non-hapū members studying the hapū } \\
\text { b. Seeking and being granted permission from home (e.g. Te Matapihi) } \\
\text { c. Kanohi ki te kanohi (seen face) } \\
\text { d. Collaborative process throughout } \\
\text { e. Issues surrounding future of oral taonga, copyright and intellectual property of hapū knowledge } \\
\text { f. Hapū waiata belonging to ahikā (in both place and role) } \\
\text { Digital technology beneficial but not the entirety of the framework } \\
\text { a. Past technologies such as transcription exemplifies this approach as transcription was beneficial but was } \\
\text { Participatory waiata learning inextricable to orality } \\
\text { a. Approach to vocality as well as the situation is indicative of how and where waiata should be sung rather } \\
\text { b. Than rigorous genre classifications } \\
\text { 5. Tutelage from the right individual(s) chosen to carry knowledge and transmit the knowledge of waiata is } \\
\text { important }\end{array}$ & $\begin{array}{l}\text { 1. } \begin{array}{l}\text { Ethics, intentions and } \\
\text { kaupapa is important to } \\
\text { establish prior to beginning } \\
\text { hapū waiata and oral taonga } \\
\text { study as well as seeking } \\
\text { permission and consultation }\end{array} \\
\text { 2. Hapū members need to } \\
\text { establish whakapapa but also } \\
\text { have to be chosen to study } \\
\text { particular hapū knowledge } \\
\text { 2. Further concerns regarding } \\
\text { the legal protection of hapū } \\
\text { oral taonga, waiata and haka } \\
\text { within the space of } \\
\text { intellectual property and } \\
\text { copyright }\end{array}$ \\
\hline
\end{tabular}

Table 6: The final table links the initial themes of the preliminary table to participant views on waiata hapū methods of preservation for Ngāti Ruakā. 


\section{Section 17: Ethics}

Victoria University of Wellington Ethics committee (See Appendix A: Section 4, Approval number 0000023669) approved this research. Due to the change of hapū participants wanting to be identified, which was discussed after receiving ethics approval, I asked participants to approve this in writing on their consent forms or verbally during the recording of the interviews. The participants were allowed to withdraw from this study at any point with any information that was discussed by the participants to be either destroyed or returned to them. The transcripts and storage of data was safely kept by myself and overseen by my supervisors. On the completion of this study, the data, recordings, transcripts and all of the information was given to Rānana Māori Committee. The relevant information, recordings, data and transcripts were originally going to be destroyed on the completion of this study, however the participants expressed throughout the consultation process and prior to the interviews that they wanted their views, opinions and stories to be kept by the hapū (Rānana Māori Committee specifically) for their future descendants to listen, learn and use for their own purposes and furthermore these discussions became a type of taonga.

This research proceeded with the protection of the hapū community as pivotal as well as being aware of past experiences with western academic practices where kuia, koroheke, tūpuna and hapū members were subjected too (Bishop, 1998; 2005; Gillies et al., 2007; Smith, 1999). Therefore engaging with the research from the perspective of leading (from myself) but overseen by kuia and koroheke of Ngāti Ruakā (the Rānana Maāori Committee) through consultation and joint collaboration was key. As discussed previously, the hapū members felt that it would be best for the dissemination of information to be given to Ngāti Ruakā (Rānana Māori Committee) 
to be further controlled and held for future hapū and whānau descendants. This was discussed throughout the consultation process prior to the interviewing stages of the study through the Rānana Māori Committee meetings.

The original intent of this study was to solely decolonise and deconstruct western methodologies that have been used to study waiata and to replace these deconstructions to create a new culturally appropriate methodology for Ngāti Ruakā waiata preservation, ${ }^{14}$ however the focus of this research changed. This research changed to adapting Whanganui kaiponu within the context of oral hapū taonga or waiata knowledge preservation. This change occurred during the interview process as the responses from hapū participants guided this course of study. This change is acknowledged here to explain the previous titles for the study (See Appendix A: Section 4).

\section{Summary}

This chapter outlines the different phases of study surrounding the research process with Ngāti Ruakā hapū participants. This chapter includes collaborative consultation as well as participant recruitment; data collection, which explores the use of semistructured interview processes and introduces the participants; and lastly, data analysis, which uses thematic analysis. These three sections highlight the logistical processes of the study.

\footnotetext{
14 The initial subject focus of the research can be seen through the name that is listed within the ethics approval form (See Appendix A: Section 4).
} 


\section{Chapter 5.}

\section{Ngāti Ruakā views and lived experiences of hapū oral taonga}

\section{Introduction}

This chapter presents the data or the perspectives and the lived experiences of Ngāti Ruaka hapū members in relation to hapū waiata preservation methodologies surrounding Whanganui kaiponu. In order to illustrate Ngāti Ruakā perspectives, this chapter highlights the information offered by the participants through the focus group interviews as well as as the individual interviews within one theme from the final table (See Table 6). This theme is Ngāti Ruakā principles and values in action and provides an interface between Ngāti Ruakā principles, values and contemporary approaches to waiata methodologies regarding preservation. This theme allows for the closer analysis of the broader aspects of hapū waiata methodologies in past, present and future spaces of Whanganui kaiponu for Ngāti Ruakā. The theme also encapsulates all of the other seven themes that underpin the overall thesis question, of Whanganui kaiponu as a culturally appropriate hapū waiata preservation methodology for Ngāti Ruakā.

The thesis presents Ngāti Ruakā views as central to the research and therefore this chapter conveys Ngāti Ruakā lived experiences and perspectives predominantly, with subtle commentary and brief analysis only to help guide the fluidity of the chapter or to add further context. Further in-depth analysis and discussion surrounding Ngāti Ruakā perspectives and lived experiences will be contextualised amongst the 
literature within the discussion chapter. ${ }^{15}$ This chapter begins by introducing the setting of the interviews and examines five different aspects of the theme; it discusses Ngāti Ruakā principles and values in action with participant views, including a brief summary that outlines their perspectives. These five aspects are summarised on table 6, and are; 1) taonga and hapū identity; 2) Whanganui kaiponu and sites of preservation; 3) ethics and intentions; 4) digital technology; and lastly, 5) participatory oral learning and teaching.

The focus group interview as well as the individual participant interviews all had very comfortable environments as they either took place on Rānana Marae, the ancestral land base of Ngāti Ruakā, or within the participants' homes. The participants also shared the commonality of being hapū members through whakapapa ties and through a sense of being whānau (whanaungatanga) with one another and with myself, reiterating the overall collaborative process of the study. The interviews brought out a range of diverse lived experiences regarding waiata within a pedagogical context, however they shared very similar beliefs and values about the future of waiata methodologies to ensure safe transmission and maintenance of its knowledge. From the discussions within the interviews, it became clear that the participants see waiata primarily as taonga. Participants were forthcoming in terms of expressing their past and present attitudes, feelings and beliefs regarding waiata hapū methodologies and related this to Whanganui kaiponu. These perspectives of waiata were about honouring hapū tūpuna, as waiata paints a picture of past events and its people and this weaved into concerns regarding the future of waiata for hapū descendants in how they uphold, maintain and carry on Ngāti Ruakā ways of waiata and taonga.

\footnotetext{
15 See page 87.
} 


\section{Section 18: Taonga and hapū identity}

Waiata encapsulated similar meanings between participants although they agreed that waiata has changed. These changes in waiata differed from generation to generation through te reo Māori neologism as well as a feeling of neglect regarding te mita o Whanganui in contemporary waiata compositions, which was referred to within the context of kapa haka performance spaces. In regards to the term, 'waiata' (which will be further examined within the section called oral teaching and learning), participants stated that this is a new term especially for koroheke and kuia. Instead the term, hapu taonga felt more comfortable for participants and was used interchangeably with contemporary notions and meanings of waiata. Participants comment that waiata contains deeper meanings than solely knowledge transmission and are an extension of the participants' themselves that further consolidates participants' whakapapa, tūrangawaewae, ahi kāa, and wairuatanga to Ngāti Ruakā. These aforementioned aspects are key components that form specific Ngāti Ruakā identities and illustrate how waiata or hapū taonga can be conduit to express these realms. The ways in which waiata or hapū taonga have consolidated participants' identities will be conveyed further below with particular quotes.

It's my whakapapa, it's my heritage and the area I live... and it tells stories from the beginning of our hapū and anything to do with around here, is of my interests (Evelyn Broad, interview, 2 April, 2017).

Let's start about that too, let's start about whakapapa, its part of our religion... our wairuatanga... To make sure... who they are. You know to be safe to give our taonga out aye? That is a way of preserving our, our taonga (Josephine Takarangi-Firmin, interview, 2 April, 2017). 
It is sort of a medium as to, like a way of waiata passing on... you know a kōrero o mua or a waiata nga kupu o mua; like hanging on to our... holding our mita (Kataraina Millin, interview, 2 April, 2017).

I suppose as you get older, your knowledge increases... and so, you know, reflecting back as a child and watching waiata being performed... I suppose as a child you don't have the depth of knowledge around waiata at that point in time... so you listen... but I've always had an affinity with waiata, you know? I'm not too sure if the meaning of waiata has changed but I think my appreciation for waiata has grown as I kind of now understand, you know; the complexities of waiata (Rāwiri Tinirau, interview, 19 April, 2017).

Waiata goes a bit deeper for me... I've learnt about waiata not directly. I've kind of learnt it through like doing a Māori society paper... We'd learn a lot about different waiata... and the translations behind them. Cause to learn the language, to learn te reo you've got to really know the culture and the history behind Māori... I think that if you wanna learn te reo and wanna learn waiata, is that... That's great, you can sing it proud and confidently but deep down do you know what it means? Behind waiata and haka. There's historical significance behind it. There's spiritual significance behind it... There's a lot of wairua behind it (Pita Haami, interview, 6 February, 2017). 


\section{Section 19: Whanganui Kaiponu and sites of preservation}

When asking about the idea of preservation as it translates to te mita o Whanganui or Whanganui kupu, participants felt that broadly Whanganui Māori invoked the term and meaning of 'kaiponu' with associations to the wider environment of Whanganui and is built from the foundations of Whanganui kaiponu ${ }^{16}$. Therefore Whanganui kaiponu has been used for the foundations of a covert ethical framework by Ngāti Ruakā for hapū taonga protection, preservation and transmission that had been reflected in their past experiences with pedagogical waiata transmissions. Participants highlighted three physical sites of Whanganui kaiponu preservation that rectified some of the ethical concerns and issues regarding the safeguarding of the pedagogical aspects of waiata and knowledge, particularly within oral to oral transmissions. Participants expressed their experiences of these sites and how this further instilled their appreciation and love for waiata as well as their views that Hui Aranga ${ }^{17}$ is vital for their future descendants. These three sites included traditional Wānanga, Hui Aranga as well as Taura Here. ${ }^{18}$ All of these aforementioned aspects will be examined further below.

\footnotetext{
16 Whanganui kaiponu and its origin and meanings are explored previously within the introduction chapter.

17 Hui Aranga refers to a yearly weekend gathering of Catholic Māori clubs where cultural events such as kapa haka are held as a celebration. Catholism has influenced some aspects of Whanganui tikanga, traditions and events for some hapū. Further readings about the history and role of Catholic missionaries and its intersections with imperialism and colonisation within the locale of the Whanganui awa can be found in Haami (2015) through the lens of waiata aroha; Young (1998) as an historical overview of the area; and Smith (1997), which explores the connection between Christianity and imperialism on Māori through justifications of the Kaupapa Māori framework.

18 Taura Here refers to traditional styled wānanga that specifically examined educating iwi members within urban dwellings, which enabled urban Māori to retain their identity and connect back to their tribal homelands.
} 


\section{Whanganui kaiponu as protection}

Tamihana Puketapu: Whanganui... is kaiponu... they don't want to share.

Meri: They don't want to share?

Kataraina Millin: Well yeah, yeah it is... it also becomes common... everybody uses?

Tamihana Puketapu: The things is Whanganui kaiponu... is Whanganui.

All participants: Yeah... yes...

Tamihana Puketapu: Is Whanganui, it's no one else. Because they're trying to take it $^{19}$ off Whanganui. Their waiata...

Kataraina Millin: That's our way of preserving...

Tamihana Puketapu: Their kōreros, their mitas... they're trying to take that all off them (Interview, 2 April, 2017).

Whanganui kaiponu comes in about, you know, maintaining some of the deeper roots of knowledge so that the sanctity of the knowledge isn't lost... but you know, there are things that outsiders can help with as well. You know, but we just have to be careful about it. But even from within we need to be careful about the motives of our own (Rāwiri Tinirau, interview, 19 April, 2017).

\section{Wānanga}

That love of waiata probably not only came, not only through Nan, from the traditional stuff but also through my parents because they would attend... they would attend a lot of our wānanga on the Whanganui river that were facilitated by Uncle [name of person] and Uncle [name of person]... Uncle [name of person], everyone called him. So at those wānanga, not only were they talking about tikanga, and you know, karanga and ruruku and whaikōrero and all of that, but waiata was a big part of it? And the teaching of waiata, what I remember was mainly at night time. So you

19 'it' refers to waiata as well as wider taonga that participants feel belong to certain Whanganui iwi and hapū within the idea of kaiponu and the act of withholding knowledge. 
know, you'd go into the... have karakia and mihimihi and stuff in the wharepuni at night then kind of like in the early hours that's when a lot of the waiata would be taught. And they were both the traditional and the contemporary as well. So you know, both myself and my brother, like were only young at the time, but that's where a lot of our appreciation for our traditional waiata was fostered... was through these wānanga on the Whanganui river (Rāwiri Tinirau, interview, 19 April, 2017).

Preservation is probably wānanga for me because it's a way of... it's a process of ensuring that the old lives on. And so through wānanga, I think that was probably the whole purpose of those wānanga was that you know, the traditional elements of our tribal identity were being carried appropriately, with the knowledge that needed to come with those things... If we talk about preservation, I would hope that it's wānanga but I think it's wānanga in the traditional sense not wānanga in the contemporary tertiary sense (Rāwiri Tinirau, interview, 19 April, 2017).

\section{Hui Aranga}

I think for us here we're very lucky that we have the Hui Aranga, a lot said, and we are trying to pass down what we've been taught... see our babies, my great mokos are going to come, and grow; that they have to keep singing to. And that's one area that we think is important. To preserve that hope they do it right (Evelyn Broad, interview, 2 April 2017)

\section{Taura Here}

Mum and Dad were quite heavily involved in what they called a... still call today Taura Here? And what Taura Here were [was that] they were groups of people that affiliated to the same iwi but lived in an urban setting. In [name of city] we had Taura Here for Mum's side from [name of town] and I think mum was the treasurer or 
something... And so what these would do, these Taura Here would so was, they would organise wānanga out at marae [name of marae] in [name of suburb] and other places and so a lot of Whanganui people could come together and would be fed, you know, by the old people... a lot of our weekend were in wānanga, whether they were here at home or down in Wellington and it was fantastic you know? Yeah it kept our connection home and all of that (Rāwiri Tinirau, interview, 19 April, 2017).

In this context Whanganui kaiponu is applied within the three physical sites of preservation. The idea of Whanganui kaiponu as protection provides a sense of cautiousness and selectiveness towards anyone, thus leading to questions of ethical process and motives of knowledge bearers. This additional perspective of kaiponu links to previously discussed meanings relating to more negative positions on kaiponu in withholding taonga transmission and meanness (Milroy, 2008). However these contrasting perspectives do not seem to remediate modern influences and issues for both Tūhoe (Milroy, 2008) and Ngāti Ruakā. These issues surround the ethical importance of context and situation in which oral hapū taonga can be performed and learnt as well as encouraging rangatahi to learn traditional hapū taonga, as Ngāti Ruakā state throughout the interviews.

\section{Section 20: Ethics and intentions}

Participants expressed that the ethics and intentions of the researcher is paramount regardless of the background of the researcher in terms of their whakapapa to the hapū being studied or if the researcher is a cultural outsider (non-hapū member). Participants continued to voice their concerns about their preference as to who would be the right kind of person to research Ngāti Ruakā. Participants also stated the most suitable research process in order for the researcher to safely study hapū knowledge to 
the ethical standards of the hapu in regards to preservation. The discussions led to several key criteria regarding the research process being collaborative between the hapū and the researcher as well as the most appropriate person being chosen. This criterion consists of establishing whakapapa within the hapū as well as ethics, motives and intent of the researcher.

Prior to the focus group interview, there had been a number of significant issues discussed during the Rānana Māori Committee meeting regarding ethics, motives and the intent of hapū members regarding knowledge. These issues involved the commodification of hapū taonga, the ethical considerations and expectations of the hapū. The discussion also urged other hapū members to look at the legality behind copyright and intellectual property for hapū taonga that are non-tangible, which includes but is not limited to waiata, haka and tukutuku. These particular areas were discussed for both hapū members and non-hapū members and were referenced to within the focus group interview through the participants drawing on relevant connections between waiata or hapū taonga and the overall legal protection of hapū taonga. Although copyright and intellectual property of hapū taonga and waiata was not overtly stated as an issue within the interview, it was brought into discussion in more subtle ways whenever an ethical consideration of hapū taonga commodification was mentioned.

Hapū taonga and waiata were discussed in belonging to ahi kā or with the ancestral land base and that one must go back to the source or home to seek permission and learn within that place. Within the context of Ngāti Ruakā where ahi kā is not only a place but also a role (Tinirau et al, 2009), one must also learn from the people taking 
care of the ancestral land base. Participants expressed that contemporary tertiary wānanga is beneficial to learn about general subject areas but ultimately it is important to go back home ${ }^{20}$ to learn specific knowledge. Participants felt that their mokopuna are somehow always led back home. These relevant participant views will be highlighted further below.

\section{Ethics, intentions and collaborative process}

Yeah, that's right ethical considerations and it's not just plucking one out and saying oh you're gonna do this; you know there's lots of other things you have to really consider before, you know, you decide to learn a waiata or to bring a waiata out of a text if it's where it goes at the moment. I mean I'm not saying that it can't be done, but it has to be done in the right way (Rāwiri Tinirau, interview, 19 April, 2017).

Kataraina Millin: I was just thinking of our men who learn the taiaha now. They don't always come home now. Once upon a [time]... you went home to learn those things. Josephine Takarangi-Firmin: But you went home to get permission as well. You went home to your kaumātua and they will tell you when you're ready; not when I'm ready... and whether you deserve it (Interview, 2 April 2017).

\section{The commodification of hapū taonga}

You see what's happened today? A lot of people, they claim that they are given the ok from Ruakā... and what happened? You see? That's what... exactly what happens, eventually and that's all around your environment within your own hapū, you know. Then it gets out to the broader... your iwi (Tamihana Puketapu, interview, 2 April 2017).

\footnotetext{
20 The reference to 'home' refers to the ancestral land base or ahi kā as a place where the hapū reside.
} 
So yeah, I mean I'm all for it, our own studying our own, but of course there's a process that should be followed and where you are aware of recent events... But we just have to be careful about it. But even from within we need to be careful about the motives of our own (Rāwiri Tinirau, interview, 19 April, 2017).

\section{Whakapapa of hapū members as researchers}

I suppose the preference is that you know, studies on our waiata would be done by our own, and when I say that, I mean not only do they have to be of our own but they actually have to be a contributing member of the hapū... the only thing that differentiates them from maybe a non-Māori or a non-hapū member doing the studies that they have whakapapa and that's it... there has to be some sort of connection home... I mean I'm all for it, our own studying our own but of course, there's a process that should be followed... The motives of the researcher is another thing that we need to understand because if it comes to the commodification of our hapū knowledge and all of that, we would probably say no (Rāwiri Tinirau, interview, 19 April, 2017).

Kataraina Millin: It's different if its our own... it's different our own; we know why, because they're ours.

Josephine Takarangi-Firmin: But then you need to find out the whakapapa... To make sure that... who they are you know, to be safe to give our taonga. All participants: Yes... yes (in full agreement) (Interview, 2 April 2017).

\section{Cultural outsiders as researchers}

There's an air of caution around that, that I think is totally viable and at the same time, if that person coming in... researching it is respectful and their trust is earnt over time. I think, then that's fine. But there is that one huge layer of caution that they 
need to get through that that's totally understandable... Thinking about the colonial history of New Zealand and seeing things like the Tohunga Suppression Act, which outright banned Māori culture... The role of Tohunga, it banned a lot of Māori culture outright even in schools. So coming and a lot of those kaumātua that have that knowledge today come from that era. And so that's where I think that caution comes from (Pita Haami, interview, 6 February, 2017).

Having a foreigner or an outsider coming in and using like a western framework won't really... first of all, I don't think it's really respectful to Māori culture either, like what you should do before you really go in is try to learn everything you can about Māori waiata and even haka... So I think it's even just talking amongst the, a lot of people in the area you know? Talking to a lot of kaumātua, kuia you know?... I think it makes me feel a little uneasy if a foreigner were to come in with that western framework and be like 'here is how I'm going to preserve your culture'... Can we get a say in how we want to preserve our culture? (Pita Haami, interview, 6 February, 2017).

My question is why would... what's their reason for wanting to study? Is there someone that they're doing it on behalf of? Someone from here? I would like to know a whole lot more as to they want to... why? (Kataraina Millin, interview, 2 April 2017).

But as Māori we have... can be quite critical of any outsider who comes in and the reason is because sometimes outsiders have come in and not done well by us. So we are careful about what we share; we, I would hope are always you know, hospitable; but we are careful in terms of what we share... There are things that outsiders can help us with as well (Rāwiri Tinirau, interview, 19 April, 2017). 


\section{Ahi kā and hapū waiata}

If I wanted to learn waiata from Ngāti Ruakā and I wanted to learn like specifically from the source and maybe if you could say maybe 'untouched'... anything kind of like that then you go directly to the source. If you kind of want to learn it in it's purist form I would go to Rānana and learn it there (Pita Haami, 20 March, 2017).

Hapū knowledge regarding waiata does belong at home... at the end of the day ahi kā make those decisions... Because they really are the, you know, the keepers of certain things and I'm not saying that those who live away aren't though. And actually I have to be careful... if it's a waiata that belongs to hapū then of course you know the ahi kā those that are at home would in my mind be responsible for those things (Rāwiri Tinirau, interview, 19 April, 2017).

These discussions convey the importance of ethical process, the background and motives of the researcher as well as how key ahi kā is for Ngāti Ruakā in decisionmaking processes and knowledge transmission. Ahi kā seems integral within the ethical process where going back home and hapū taonga learning is very important. However these open further discussions about the contemporary realties for whānau members who are living elsewhere, who are unable to attend regularly or who are dislocated from their ancestral land base and whakapapa. These discussions further inform very pivotal components of Whanganui kaiponu as a culturally appropriate hapū methodology for preserving waiata in terms of decision-making, processes and ethical standards. $^{21}$

\footnotetext{
${ }^{21}$ Kaiponu as a methodology for Ngāti Ruakā oral hapū taonga or waiata preservation framework is created from the basis of Whanganui kaiponu. This methodology and framework is sumamrised on page 110.
} 


\section{Section 21: Digital technology}

Participants had similar views pertaining to the use of digital technology surrounding preservation methods for waiata and for hapū taonga. Participants discussed past hapū tūpuna being highly adaptable by utilising technology of the time to their advantage and relating these ideals to present issues encompassing current digitalisation technologies.

Participants also agreed that digital technology is beneficial but as a smaller tool within a wider framework but that digital technology itself should not be the entire framework. The ways in which digitalisation was beneficial for preservation efforts was discussed through participants past interactions and experiences with Waka Huia documentaries. Another experience includes a radio station recording of a certain waiata performed at the first Whanganui Hui Aranga, which were recordings eventually returned to the hapū. Participants argued that in order to uphold Whanganui kaiponu that ethical safeguards need to be in place. However participants ultimately feel a sense of inevitability surrounding modern technology and digitalisation in relation to hapū taonga.

The area of traditional transcription (written notation) exemplifies a past and present technology that was often used by hapū tūpuna, outside researchers and participants as a tool in a wider framework of waiata preservation, transmission and pedagogy (McLean and Orbell, 1975; McLean, 1996). This method had nuanced outcomes for participants as they saw the benefits of being able to use transcripts and notation in terms of figuring out the rangi ${ }^{22}$ of waiata. However participants were very critical of

\footnotetext{
22 Rangi refers to the tune of a waiata.
} 
the outcomes and held ethical concerns of its widespread use. These concerns included the importance of accurate translations of waiata from te reo Māori to English as well as transcription being a sterile source of spiritual connection personally for some participants. When asked about transcriptions specifically from kuia and koroheke they shifted back to the oral nature of waiata and reiterated how waiata was never written down for them. Rāwiri Tinirau also shared an experience, which is highlighted below about a kapa haka who wished to learn and eventually perform a waiata from Ngāti Ruakā. He discussed the multiple layers regarding ethical concerns that intersected different technologies of audio digitalisation as well as transcription within waiata pedagogy and preservation. Participant views discussing digital technology and transcription will be explored further below.

\section{Technology and digitalisation as a tool}

Use digital technology as a tool but not the method... use it as a tool in your tool box but don't make it... don't make it your primary method... we can very much take advantage of technology. It's a tool in our tool box. But don't make it the whole method of how your teaching them (Pita Haami, interview, 20 March, 2017).

I think they're great... I think our tūpuna would have used them if they were here today because they're very forward thinking people. They used whatever technology resource that was available to them for whatever reasons... there has to be the proper safeguards in place...Yeah, they are not the answer... They're just a tool that we could use and I think it's a tool we should use; but you know, pending... Having those safeguards in place (Rāwiri Tinirau, interview, 19 April, 2017). 


\section{Transcription}

I think it depends on the waiata... sometimes all we're left with are words. And if, you know, those words had been... translated into musical score, we would have the rangi... if we want to bring these words out we sometimes have to really think about the waiata and adapt the rangi that's suitable. But if we had the musical score we wouldn’t have to do so much thinking! (Rāwiri Tinirau, interview, 19 April, 2017).

Yeah, a real struggle as to how... what's the best way we can preserve it, does the oral tradition work... of oral to oral? Some would argue that it doesn't really anymore, people would much rather have it notated on a piece of paper... That if you if you were to do it that way or maybe even have like a whole website dedicated to waiata, where you can search up and look up different waiata, I mean there's that spiritual connection that's gone. That connection to your whakapapa gone you know (Pita Haami, p. 14)... Yeah and there's that spiritual connection gone. If you were to just read it from a piece of paper (Pita Haami, 20 March, 2017).

\section{Intersection of audio digitalisation and transcription}

The group started to learn a waiata that belonged to Ngāti Ruakā and that was in the lead up to the regional competition. And even though the majority of members would have whakapapa to Ngāti Ruakā, there wasn't kind of any discussion with Ngāti Ruakā about doing that particular waiata... Then I got involved. I suppose it kind of put some things to rest you know in terms of some of the concerns that were being raised outside of the group about what the group was doing... But if that kind of stuff had been put in place first... There was an audio of someone performing or singing that particular waiata that was found but it was incomplete; and there were verses that were incomplete and so some people took it on themselves to listen to the rangi and to try and you know, tie in and adapt the rangi to those parts that weren't on the 
recording... As I've thought about it; well I thought were they the right people to do that? (Rāwiri Tinirau, interview, 19 April, 2017).

These discussions surrounding the use of digital and audio technology within the context of adapting Whanganui kaiponu as a culturally appropriate hapū methodology for preserving waiata takes into account the importance of utilising current technologies of the time that can be to the benefit of teaching knowledge. These discussions also indicate that Ngāti Ruakā do not want a total immersion of digital and audio technologies that has been done by Ka'ai-Mahuta (2010) as an online repository system of waiata and is accessible to all Māori. These aspects touch on previously discussed subjects of ahi kā and the importance of place in regards to the ethical standards, decision-making processes, learning and teaching of waiata or hapū taonga. These aspects indicate further potentiality in digital and audio technologies helping whānau members who are unable to come back to ancestral land base for taonga learning. Ka'ai-Mahuta (2010) found this to be one of the many rationales in creating an online repository system that is accessible for Māori and this justification could be adapted for and monitored by Ngāti Ruakā to align with Whanganui kaiponu.

\section{Section 22: Participatory oral learning and teaching}

Participants shared their experiences of waiata learning as being primarily experiential, participatory and oral due to specific vocality and rhythmic qualities having to be taught. These further indicated how waiata was performed within social events and thought of amongst genre categorisations. In terms of ethnomusicological standards of genre categorisation, koroheke and kuia participants felt that the term 
'waiata' was a new term. Participants further stated that the way in which waiata was sung as well as the specific social circumstances was indicative of where waiata should be sung and that waiata did not have definitive genre categorisations. Rather waiata has multiple cross genre classifications, that they would "describe something... rather than giving it a name" (Kataraina Millin, interview 2 April 2017) or waiata didn't belong to a single rigorous genre category at all and more to a social event such as pōwhiri.

Waiata was never written down for a majority of participants and they had to learn in impromptu ways and repetitive social circumstances (e.g. karakia as night prayers) of singing waiata or oral hapū taonga. This led into a discussion surrounding pedagogical processes of waiata such as the importance of being tutored by someone either older or with the right skill set, the suitable individual that would do well to "the benefit of that knowledge" (Rāwiri Tiniraru, interview, 19 April 2017) and the ideal ways in which waiata should be taught to hapū standards. Participants also stated that their introduction to waiata was through a type of covert osmosis through the communal wānanga environment, the immediate people also learning as well as the skilled tutor being integral influences within the learning process.

Participants made further associations of how this can help performers towards developing deeper spiritual understandings and meanings for themselves that connects them to the waiata and honours the composer, its kaupapa as well as the emotive qualities of the waiata. These deeper understandings made by the performer contributes towards the meaningfulness of the performance and significance of being 
in 'the moment', which in turn creates more positive and supportive relationships between tutor and student of waiata.

It is important to acknowledge that the ability to converse in te reo Māori competently influences present and future learning, teaching and spiritual connections to the kaupapa of the waiata. Statistics New Zealand (2013) show a decrease in the Māori population able to converse in te reo Māori from 25.0 percent to 21.3 percent, with only a increase in the age group over 65 , and with no increase in any other age group from 1996 to 2013. These statistics have definitive influences on present and future teachings of waiata and raise further questions about the spiritual connections to waiata for those who do not speak te reo Māori well. While these queries are valid and were not explicitly talked about within the interviews, this could be due to an assumption that learners of hapū taonga and waiata within Ngāti Ruakā would have a certain proficiency to speak and understand te reo Māori or that Ngāti Ruakā have been initally cautious historically about who they gave their taonga and waiata, which is in reference to Whanganui kaiponu. This caution could perhaps take into account one's proficiency of te reo Māori as part of the criterion for Ngāti Ruakā decisionmaking when giving and transmitting taonga and waiata to certain people, however this is spectulative and requires further examination. 


\section{Participatory oral learning of waiata}

Josephine Takarangi-Firmin: You open your eyes and our eyes were the window for the waiata that, you know, ngā waiata.

Toreheikura Puketapu: You weren't forced to do it. You're not forced to do it.

Angeline Ann Haami: My Father was the one. He would never let anybody write anything down. You had to learn it here (pointing to ears) here (point to head) and there (pointing to heart) (Interview, 2 April 2017).

Soak it in... you catch it... oral; it's oral you catch it (Kataraina Millin, interview, 2 April 2017)

But you soon caught on and that's how I caught on. That's my way of a karakia is through them. Just listening to them and we just pick it up... And as they said it, it was never written down and it wasn't. Nothing was written down. Well they always thought that you have it in here (points to head) and here (points to heart). Make sure your ears are listening (Angeline Ann Haami, interview, 2 April 2017).

\section{Genre categorisations}

I'll give you a sample of a pao, to now, and she does it all the time in her pōwhiri, in her karanga; [name of person] you never hear her words... you know? She's just doing the air of the words, within her words... but within the air, but you don't hear her words. And that's the type of pao. But the old lady and them was deeper still... You never hear the words; her words much but she's doing it within her (vocal example given by participant) you know? (Angeline Ann Haami, interview, 2 April 2017). 
But a waiata can have more than one classification; that's what I do know. Because it depends on the way it's sung; it depends on the context within which it's sung...

What might be a waiata aroha in this instance, is a waiata tangi in this instance; same song; but different context for the waiata... it's murky but you have to know the waiata to know (Rāwiri Tinirau, interview, 19 April, 2017).

\section{Tutelage and the suitable tutor}

Yeah I mean it has to be taught by the right person and... Ideally you'd have someone who has a strong connection to the composer or if it's just waiata; that would be able to facilitate that process, but not always is that possible; for many reasons you know there's lots of family that don't know that they descend from great composers or that tupuna in their whakapapa composed certain waiata... It's more kind of, what is the skill set required of a particular... for a particular kaupapa... if the question is tutelage, I mean yes. It's important (Rāwiri Tinirau, interview, 19 April, 2017).

I think the whole structure of tutelage, say from a kuia to a moko or a kaumatua to any tamariki... I feel that connection is still important (Pita Haami, 20 March, 2017).

If things were great you know if you'd learnt a waiata you would take them to those places... so they can see the landscape, they can see the wahi tapu or these points of interest. Because then they'd be able to you know sing the waiata with these pictures in their minds rather than them just being words ((Rāwiri Tinirau, interview, 19 April, 2017). 


\section{'The moment'}

They can go to these places and see them for what they are and to feel the... you know the mauri of those places to feel the mauri of the composer (Rāwiri Tinirau, interview, 19 April, 2017).

And I think there's a spiritual connection that you can't get across when you just write it down on a piece of paper and archive it... And being like 'whole damn' you know? This is... I'm feeling it... It's that real in the moment thing about music especially with haka and waiata that I think it really important to understand and it's the only thing you really understand it when you in that moment (Pita Haami, 20 March 2017).

\section{Communal and environmental osmosis of waiata learning}

My passion and interest in waiata has always been there because of the exposure at quite a young age and that's through wānanga but also with being connected home and when I say home I'm talking about Rānana... Just being a part of that I suppose through what would call it a bit of osmosis?... Yeah you kind of absorb these things whether it was planned or not aye? (Rāwiri Tinirau, interview, 19 April, 2017).

[In reference to a school where this participant observed and talked to the teacher about teaching waiata to Year 9 students] 'Yeah I'd give them the piece of paper they would have to in their own time to really mull over what the waiata would mean for them' Cause what they would do, they would have an hour of study and they would be given no homework in the first few weeks and that they would do in that whole is just study the waiata. Learn the waiata back to front, really mull over the meaning for them. What the waiata would mean for them and how unique it would be for them 
then once they've learnt it they can come sing it with all of them [the rest of the school]... There's a solidarity there too (Pita Haami, 20 March 2017).

From these discussions, the experiential and participatory elements of waiata pedagogy are pivotal and inseparable with orality. Participants intrinsically referred back to the orality of waiata in reference to transcription (notation) and discussed their lived experiences within the context of communal learning environments where everyone was made to participate actively in impromptu ways. Orality further dictated the way in which waiata was sung, could be classified and sung within certain social circumstances, which is contrastive to ethnomusicology waiata genre classifications previously used (McLean and Orbell, 1975; McLean, 1996; Orbell, 1991).

\section{Summary}

This chapter examined key data collected from participant interviews through examining one theme set out in Table 6, which explores Ngāti Ruakā principles and values in action. This chapter further illuminated solely Ngāti Ruakā views with subtle commentary and analysis as this research places their lived experiences and perspectives as central in regards to waiata preservation. The theme examined within this chapter looked at the interface between Ngāti Ruakā principles, values and contemporary approaches to waiata methodologies regarding preservation and is a summary of all of the other seven themes. The five aspects examined within this chapter highlight crucial theoretical underpinnings as well as examples of a practical application of Whanganui kaiponu as a culturally appropriate hapū methodology for preserving waiata and taonga. 


\section{Chapter 6.}

\section{Ngāti Ruakā views in comparison to waiata literature}

\section{Introduction}

This chapter explores the primary research question through analysing and discussing the intersections between Ngāti Ruakā participant views and the earlier literature regarding culturally appropriate hapū waiata methodologies. The discussions throughout this chapter of hapū participant views as well as relevant literature establishes kaiponu as a framework for Ngāti Ruakā oral hapū taonga or waiata preservation. This chapter will be divided into three parts and examines themes that will be re-contextualised from the previous literature. The three themes include; the significance of orality; the influences of technologies; and lastly, Whanganui kaiponu as a methodology and framework.

\section{Section 23: The significance of orality}

A lot of academics think that oral to oral tradition isn't that fool proof because one way someone learns it, it could be transmitted differently to another person it can be changed over to the original one... that's kind of the way things permeate in a way. I think it's the way maybe things grow (Pita Haami, interview, 6 February 2017).

The literature regarding oral history has been historically utilised by some Māori to settle land or environmental legal cases as well as transmit significant iwi, hapū and whānau knowledge or taonga. The literature has shown examples of the Crown disputing the authenticity and legitimacy of oral history (Mahuika, 2009; Mutu, 2009). Waiata along with oral history is located amongst wider Māori oral 
historiography however waiata specifically embodies tonal, rhythmic and mnemonic qualities, thus aiding in easy memorisation of important information (Ka'ai-Mahuta, 2010). Comparably to Mahuika's (2009) analysis of oral history as well as Mutu's (2009) Treaty negotiations (Wai 17; Wai 45), Ngāti Ruakā has historically drawn on oral history, specifically waiata as a method during past dealings with the Māori Land Court, which involved using traditional ahi kā rights ${ }^{23}$ to formulate a 'take' (Tinirau et al, 2009).

Ngāti Ruakā view waiata as a medium for 'oral hapū taonga' and is intrinsically connected to orality, however 'hapū taonga' has a much broader meaning incorporating other art forms such as arapaki ${ }^{24}$. Although not stated by Ngāti Ruakā explicitly, perhaps this term could also define whakairo and tā moko. Like many iwi, Smith (1999) argues that there are Māori realms of identity and community, which can be expressed through three ways: the geographical (ahi kā and tūrangawaewae), political (rangatiratanga and ahi kā) as well as genealogical (whakapapa). For Ngāti Ruakā, waiata as oral hapū taonga can reiterate these three realms of hapū identity and community. These realms of identity for Ngāti Ruakā as well as their senses of indigeneity are then expanded upon through more intricate markers. These include waiata conveying a deeper sense of spirituality that is specifically geographic to Whanganui individuality throug tikanga Whanganui, wairuatanga, te mita o Whanganui as well as Whanganui kupu (Josephine Takarangi-Firmin, Kataraina Millin, Evelyn Broad, interview, 2 April 2017; Pita Haami, interview, 6 February

\footnotetext{
23 Tinirau et al (2009) within this study examines the ways in which ahi kā meanings are contextualized within Ngāti Ruakā as being both a place as well as a role over the hapū ancestral land base. In this instance, ahi kā refers to traditional meanings of providing evidence for having a 'take' or claim over particular sets of land for legal purposes.

24 Arapaki is also known as tukutuku, however this is in accordance with te mita o Whanganui.
} 
2017). Waiata as oral taonga has been explored within previous literature with other iwi (Ka'ai-Mahuta, 2010; Milroy, 2008; Mutu, 2009).

As stated before, Ngāti Ruakā view waiata as oral hapū taonga and particularly with koroheke and kuia participants who felt that the term 'waiata' was a new term. However all of the Ngāti Ruakā participants felt that Ngāti Ruakā waiata was oral hapū taonga and both terms were used interchangeably within the discussions. This is particularly pertinent with ethnomusicology literature studying waiata, which has designed standards of genre based modelling for waiata categorisations in often rigorous groupings that did not allow for waiata to be placed in more than one genre (Ngata, 2004; 2005; 2006; 2007; Orbell, 1991; Moorfield and Johnston, 2004; McLean and Orbell, 1975). These findings are important for future waiata or oral hapū taonga study, as this sheds light on a potentially new perspective and can further inform the ways in which waiata is categorised into genres, if this process is required or more broadly, how waiata is approached contextually on the outset for the researcher.

Furthermore, the categorisations as well as the participatory pedagogical nature of waiata is integral to orality, as certain vocal and rhythmic qualities had to be passed down and these elements also determined when and how waiata was performed within social events. Ngāti Ruakā perspectives and lived experiences of waiata or oral hapū taonga contradict previous ethnomusicology literature regarding strict waiata genre categorisations (Ngata, 2004; 2005; 2006; 2007; Orbell, 1991; Moorfield and Johnston, 2004; McLean and Orbell, 1975). Waiata or oral hapū taonga contains multiple cross genre classifications and the same waiata can be sung concurrently but 
in different social events such as pōwhiri as well as tangihanga and still be able to exude different meanings and contexts (Angel Haami, Chris Tapa and Lye Millen, interview, 2 April 2017; Rāwiri Tinirau, 19 April 2017).

Music performance methods became evident through participant experiences as well as a type of pedagogical participation that became significant during the focus group interview, where oral hapū taonga was performed, specifically a karanga (or pōhiri) and the term 'performed' itself is an inadequate term to describe the singing example sung by my Nanny (Angeline Ann Haami, interview, 2 April 2017). Rather the karanga was 'given' as taonga to exemplify the way she was taught by the old people to sing, the proper breath control required and how her relations sung karanga too. Afterwards and in private with my Nanny, she asked me to show her what I had learnt regarding the karanga vocal example given during the focus group interview. I was unsuccessful and I found the type of karanga that she sung very difficult to comprehend and relay back to her. I based this difficulty on my vocal training as a contemporary singer, which had not prepared me for karanga or for the waiata that she knows. My Nanny is a highly knowledgeable and well-respected hapū member especially with waiata and oral hapū taonga and this experience as well as all my opportunities to be with her has been a privilege.

However despite my difficulties, this particular experience between my Nanny and I highlighted how the orality of hapū taonga guided the preferable ways for Ngāti Ruakā to teach, transmit and receive knowledge. These ways required that the tamariki, rangatahi or person be encouraged and endorsed by koroheke and kuia and for this person to actively participate within the learning of waiata or oral hapū 
taonga: whether that be through the influences and osmosis of the environment, by others as well as through their tutors. Participants reflected on these aspects through their own learning experiences set by their past tutors, which called for participants to extemporise, recite and experience hapū taonga orally back to the tutor, which they feel is an important way of teaching still. This experience highlighted the following; the importance of oral-to-oral transmission today; the significance of whānau relationships; the communal environment; as well as the participatory, often impromptu and spontaneous pedagogy (Angeline Ann Haami, Kataraina Millin, Josephine Takarangi-Firmin, interview, 2 April 2017; Rāwiri Tinirau, interview, 19 April 2017; Pita Haami, interview, 6 February 2017).

This experience of teaching and receiving knowledge touches on ethnomusicology literature that examines the ways in which the researcher can capture and analyse experiential and participatory processes of music through performance. These music performance methods turn to interdisciplinary sources to help articulate such moments (Holmes and Holmes 2012; Jenson, 2015; Jenson; 2016; Berger, 2010; Herbet, 2010). These interdisciplinary sources stem from the music performance methods, which are phenomenologically informed and this aspect invoked initial concerns about the ways in which these methods could be used for this study. This study is collaborative with Ngāti Ruakā and phenomenology in particular contains distinct terminology that has potential to complicate and misconstrue information. An additional concern came from the complexities of possibly navigating and adapting phenomenology to a primarily Kaupapa Māori framework centered on hapū knowledge. 
The music performance method used by Holmes and Holmes (2012), while phenomenologically informed, places the semi-structured interview process as the most important aspect of their methodology. This research uses this aspect along with kanohi kitea, which further involved almost a year of observations. Berger (2010) argued that the semi-structured interview process reveals partial elements and that the musical performance itself should be the focal point in which people engage with texts (or within this case with orality) and bring them into lived experience through musical performance (Berger, 2010, p.10).

On the other hand, the vocal example (karanga) given by my Nanny was a smaller component within the interview process and the ways in which this study was influenced by phenomenology was only through the music performance method by Holmes and Holmes (2012) and not through Berger's (2010) views. ${ }^{25}$ This particular method employs phenomenological methods partly and places more value on the lived experiences through semi-structured interviews to provide the contextual and background elements to music performances. However, within the context of Berger's (2010) views, the karanga did uncover deeper understandings through the wider implications of hapu participatory learning and its intersections with orality. This was an outcome Berger (2010, p. 10) sought to achieve by inquiring into the ways the musical performance contributed to people's expressive culture. The full incorporation and adaptation of phenomenology within oral hapū taonga studies has future potentiality for further research.

\footnotetext{
25 This is explored within the methodology chapter (see page 34) as well as the literature review (part two) chapter (see page 25).
} 


\section{Section 24: The influences of technologies}

I think our tūpuna would have used them if they were here today because they're very forward thinking people. They used whatever technology, resource that was available to them for whatever reason. However it's the same sort of thing; there has to be the proper safeguards in place... they're not the answer... They're just a tool (Rāwiri Tinirau, interview, 19 April 2017).

Ngāti Ruakā and their previous use of transcription correlate with how they view current and future uses of digital and audio technology for oral hapū taonga. Participants hope that digital and audio technology will be something of a smaller tool that can be utilised within a much larger framework and methodology in relation to oral hapū taonga preservation and pedagogy, just as transcription has been in the past on Ngāti Ruakā oral taonga. The literature using traditional written transcription (notation) has been a favourable and primary tool among past ethnomusicologists specifically studying Māori music (McLean and Orbell, 1975; McLean, 1996). However its use has been discontinued within larger ethnomusicology circles internationally (England et al, 1964; Marian-Bălaşa, 2005). The use of transcription contrasts with the caution felt among Ngāti Ruakā members who have identified its past mistranslations from te reo Māori to English as well as a difficulty in the transmitting the wairua within the waiata. While some hapū members found it very useful for figuring out certain rangi, there still were ethical concerns within the hapū overall. These concerns included; the translations; understanding the kaupapa of the waiata; as well as the right person being able to hold the knowledge and to teach the waiata. Others however did not see connections to written form, due to waiata as hapu taonga always and inherently being oral and to never be written down and if so, only 
for learning purposes for a few hapū members, which was eventually taken down after a few hours.

These viewpoints from Ngāti Ruakā surrounding transcription mirror viewpoints on digital and audio technological advances on oral hapū taonga and further bring into question the past appropriateness of transcription on waiata or oral taonga by McLean $(1975 ; 1996)$ and Orbell (1975) particularly. McLean $(1975 ; 1996)$ and Orbell's (1975) use of transcription displays the need for cultural sensitivity and awareness of iwi and hapū tikanga when studying or recording oral hapū taonga or waiata. Additionally, it is important to have ethical safeguards in place to understand and utilise new tools in culturally safer and beneficial ways, which will arise from digital and audio technologies.

During the thesis, transcription was used as a smaller and beneficial component to teach waiata between my Nanny and myself. My Nanny is part of a kapa haka (with other kuia of the hapu and iwi) and for their choral piece they had to perform a waiata, however the kuia only received the sheet music (written notation) of the waiata to learn outside of kapa haka practices and my Nanny could not read sheet music but wanted to practice in her own time. After one Rānana Māori Committee meeting, my Nanny gave me the sheet music and asked for me to play her the waiata on an old piano sitting outside within the marae courtyard. I played her the waiata on the piano and sung through the melody with her. She also wanted me to take the sheet music and learn it more thoroughly so that I could teach it to her in an oral way later. 
This incident during the research relates to Hellier-Tinoco's (2003) and Kisliuk's (1997) literature critiquing ethnomusicology relationships formed within the researchers experiences of study and further intersects with Bartunek and Louis's (1996) ideas surrounding insider/outsider joint methods. This interaction further reiterates other participant views, which highlights the usefulness of transcription in figuring out the melody of waiata and also as a smaller component to waiata learning. This is because my Nanny wanted me to learn the waiata comprehensively and to teach her the song orally rather than completely following the sheet music, thus using transcription methods as a smaller tool within the wider learning process.

This indicates a specific oral pedagogy explored previously by Ngāti Ruakā and how transcription as a smaller method brought out the casual reciprocity of learning and knowledge exchange within the context of whānau relationships. Not only is this knowledge exchange based around the skill set of each person, but it also occurred in a reciprocating cycle, where my Nanny showed me the way to sing karanga and I showed her how to sing a waiata according to notated music.

This specific incident of knowledge transmission represents the importance of age within Māori society, correlating with wisdom, mana, high skill level and experience sometimes demonstrated within kaumātua status (Durie, 2003). This incident in relation to the mana of age touches on the significance of wāhine roles within traditional Māori society regarding waiata in two ways: the first is how this highlights the whānau relationship between kuia (a person with age, mana and skills) and expressing these qualities to their mokopuna through knowledge transmission. The second is how wāhine overall played vital roles within the oral transmission of iwi, 
hapū and whānau knowledge by being a prominent group in contributing towards waiata compositions (Mikaere, 1995; Smith, 1997). This was a way of safekeeping history and acting as a conduit for hapū identity.

The amalgamation of these critiques and ideas are also weaved into this particular experience with my Nanny, which occurred outside of the interviews but within the confines of the research process and brings to the foreground my absence ${ }^{26}$ within the hapū community as an adult. This further reinforces my own personal connection to whānau, who had come in and out of my life resulting in muddled and often diaspora centred attitudes towards my own identity and role within the hapū and whānau. These personal experiences that interweaved within the study touches on HellierTinoco's (2003, p. 28) position on ethnomusicology regarding the rigid dichotomy between the separation of 'scholarship' and 'experience' and how shared musical experiences overlap this limiting binary. The research as a whole as well as having to use transcription processes has helped revive and consolidate my own personal identity and role within studying oral hapū taonga with whānau, koroheke, kuia and fellow hapū members.

Ngāti Ruaka viewpoints on digital and audio technology see its use as a smaller component within a much larger framework regarding oral hapū taonga preservation and pedagogy and that it should just remain a minor tool. This however comes across as a compromise accepted by koroheke and kuia, as they feel an inevitability surrounding technology and that the "modern age [would] take over" (Bernadette Hadfield, Josephine Takarangi-Firmin, Kataraina Millen, interview, 2 April 2017).

26 Absence refers to kanohi ki tea (or seen face) as being a contributing, active and participating member of the hapū. 
This illustrates understandably cautionary perspectives surrounding audio and digital technology, which contrasts to other Māori such as Ka'ai-Mahuta (2010), who have embraced the extensive use of digital and audio technological methodologies and frameworks being used to form online repositories via the Internet.

The use of digital and audio technologies has been exemplified through the work of Ka'ai-Mahuta (2010), who created a template for an online repository for waiata and haka. Ka'ai-Mahuta (2010) established a contextual, ethical and non-traditional system based on traditional principles of orality. Ka'ai-Mahuta $(2012$, p. 105) has stated that the aim of this repository system was to demonstrate:

The interface between recovering traditional knowledge and storing this through innovative technology for future generations. The repository is primarily concerned with the preservation of knowledge and the celebration of identity and culture.

While Ngāti Ruakā members expressed their pride among hapū tūpuna utilising technology, the full immersion of using an online audio and digital repository to preserve oral hapū taonga conflicts with Whanganui kaiponu and tikanga likening it to “opening pandora's box in a way. It's like you give all your information out to someone that maybe you shouldn't have fully trusted" (Pita Haami, interview, 6 February, 2017).

Further issues were raised concerning audio and digital technology in relation to Whanganui kaiponu and were brought about through a discussion within the Rānana Māori Committee, which occurred prior to the interview. These issues questioned the appropriate ethical process, consultation as well as the options for hapu on the legality of copyright, intellectual property and commodification of hapū taonga that is oral or art. These concerns were overarching within the focus group interview whenever 
ethics of a person using hapū taonga with or without the consent of the hapū was mentioned. These concerns were also raised with Whanganui kaiponu in maintaining the sanctity of knowledge for just the hapū in conjunction with the feelings of inevitability surrounding digital and audio technology becoming a conventional method of preservation. The legality of oral hapū taonga for Ngāti Ruakā can also touch on themes surrounding the idea of ownership and viral accessibility by all for the purposes of appropriation, exploitation or copying without proper acknowledgement of its origin.

These concerns expressed by the hapū intersect with Seegar (1996) regarding the use of ethical processes for the commodification of indigenous music and performance through archival systems. Oral hapū taonga or waiata within the context of Seegar's (1996) work presents underlying issues on principle, as oral hapū taonga from Ngāti Ruakā is not intended for commercial gain or commodification. However Seegar's (1996) ethical framework for ethnomusicologists and their archiving system in regards to copyright laws and intellectual property can still be used as a template towards preservation efforts. Seegar's (1996) work as a template can be altered to fit into New Zealand law as well as Ngāti Ruakā ethics however this could conflict with tikanga Whanganui and kaiponu. This is an area that needs to be more closely examined within future research that bears the aim of oral hapu protection or that takes a nuanced approach.

Returning to Ka'ai-Mahuta's (2010) repository system, which illustrates a form of archiving, can help the Māori diaspora living elsewhere to reconnect through remote access and this can be invaluable within the context of contemporary Māori realities. 
However this system is precarious for Ngāti Ruakā at the moment and in order for the hapū to proceed within this framework hypothetically, a requirement includes an ethical process aligning with tikanga Whanganui and kaiponu. It would also involve comprehensive hapū involvement within every aspect of its creation. This process may entail meticulous access rights to certain oral hapū taonga that is either highly restrictive or accessible dependent on the viewer or listener. Further contentious issues within establishing this system would also include the pedagogical dynamics changing; the decline of te reo Māori affecting both teacher and student; how the transmission of wairuatanga through oral hapū taonga can be done through an audio and digital medium; and lastly, the systems akin to archiving that participants have discussed as being "clinical” and "sterile” (Rāwiri Tinirau, interview, 19 April 2017; Pita Haami, interview, 6 February 2017).

Furthermore within the context of Ngāti Ruakā, this primarily digital system (Ka'ai Mahuta, 2010) does not align with the ethical standards of tikanga Whanganui and kaiponu and how it operates currently in relation to the preservation of oral hapū taonga. Whanganui kaiponu ensures that knowledge is secretively transmitted and held and that other iwi or hapū do not have access to this knowledge as it is only meant for them as well as certain members of the hapu from which it originates.

The hapū would have to navigate through very important questions if they were to theoretically adopt an online repository system for oral hapū taonga preservation efforts and some of these include; how does the hapu put proper safeguards in place? Who is the right person within the hapu to protect, manage and oversee this system? How would they proceed in authorising and allowing access for other hapū members? 
This digital process would further alter kanohi kitea with the hapū, the act of 'going home' to the ahi kā and elders as well as the ongoing consultation process known as staple customs or tikanga when seeking permission and working collaboratively with hapū on hapū matters.

Other questions regarding the primary use of a system such as Ka'ai-Mahuta's (2010) includes the reliability of the technology along with the rapid development of different audio and digital technologies, as technology presently can become outdated very quickly. These questions within the context of copyright and intellectual property from Seegar (1996) along with digital and audio repository systems (Ka'aiMahuta, 2010) being a national resource directly conflicts with the privacy of Whanganui kaiponu ethics and the act of maintaining knowledge that is solely meant for certain members within the hapū and not for others. ${ }^{27}$

\section{Section 25: Kaiponu methodology, framework and ethics}

The thing about me, about waiata is that it comes from people who have origination, who have originated there, feeling their expressions amongst themselves. Not... and it wasn't supposed to be for everyone; it's theirs. It's their mana. Now if you look at, well it goes viral aye? That everyone wants a copy (Tamihana Puketapu, interview, 2 April 2017).

The idea of oral hapu taonga being widely accessible, succumbing to the potentiality of becoming viral or being over shared is antithetical in relation to Ngāti Ruakā perspectives and Whanganui kaiponu. The literature that examined prospective

\footnotetext{
27 The term 'others' refers to hapū members, non-hapū members as well as cultural outsiders who are not chosen
} to receive knowledge. 
methodologies and frameworks used across multiple disciplines ${ }^{28}$ interrelate with different parts of Whanganui kaiponu and perhaps, articulate some components of preservation regarding hapū taonga but within predominantly western frameworks. This section will examine my proposal of a Ngāti Ruakā centered framework called kaiponu, which is a type of ethical framework regarding oral hapū taonga or waiata preservation adapted from Whanganui kaiponu meanings of retaining knowledge. This last part brings together the multitude of Ngāti Ruakā lived experiences and perspectives that have been discussed throughout this research and particularly within this chapter to answer the primary research question as well as specify kaiponu underpinnings. The primary research question is to examine the ways in which Ngâti Ruakā want to preserve and transmit their waiata through culturally appropriate hapū methodologies and frameworks and this can be articulated through adapting Whanganui kaiponu.

Ngāti Ruakā use Whanganui kaiponu meanings of protection to encapsulate their selective treatment of knowledge transmission in conjunction with their specific locale and I propose that kaiponu can be further adapted to encompass a type of framework for oral hapū taonga preservation and pedagogy for Ngāti Ruakā. There are three major facets surrounding kaiponu as a framework and these will be explained further in turn. These three facets include; 1) the ethical process, which will examine insider/outsider ethical processes and ahi kā decision making; 2) pedagogical methods, which will look at the environmental and technological tools that can be used; and lastly, 3 ) the sites of preservation, which will explore the application of hapū oral taonga or waiata teachings.

\footnotetext{
28 This statement is referring to the literature review (part two) chapter that examines methodologies, methods and frameworks (See page 25).
} 


\section{Section 26: The ethical process}

Ngāti Ruakā has stated that the importance of establishing an ethical process is paramount and should involve prior, ongoing and post-study consultation. The research should be a collaborative process, where the researcher must go and seek the permission and support from the implicating hapū or whānau as well as the ahi $k \bar{a}^{29}$. The consultation process of obtaining permission and support is ongoing before, during and after the research and involves travel to necessary committee or board meetings with prominent koroheke, kuia and hapū members present as well as being flexible to the hapu in terms of time, which always goes at their pace. This also gives the hapu the opportunity to examine the following; the intentions and motives of the researcher; the benefits or concerns the hapū have for the research; as well as having a collaborative forum for ongoing suggestions and changes that need to be amended throughout. The ethical process should also align with tikanga Whanganui ${ }^{30}$ and these incorporate Whanganui kupu, mita and customs (Tinirau et al, 2009).

Different literature highlighting the researchers own cultural identity and relationship to the culture in which they are studying has been an important point of discussion within various disciplines and some of the perspectives that have been examined include Bartunek and Louis (1996), Dwyer and Buckle (2009), Smith (1999) and Tinirau (2008). ${ }^{31}$ These publications explored the different ways in which the researcher can be positioned in relation to their own cultural identity; how this intersects with the research they are conducting and their relationship with the people involved and participating within the study. The position of being a cultural insider to

\footnotetext{
29 Ahi kā refers to the role of looking after the ancestral land base through continuous occupation (Tinirau et al, 2009).

30 This is explored comprehensively within the methodology chapter (see page 34).

31 See page 28 .
} 
in relation to the aforementioned literature illustrates how despite the researcher being trained in western frameworks and processes, that this position is a place of privilege in terms of its access by whakapapa to certain knowledge (if allowed) and that objectivity does not inherently resonate as legitimacy and authenticity of data (Tinirau, 2008; Smith, 1999).

Furthermore, Ngāti Ruakā expressed that the position of the researcher in terms of being a cultural insider or outsider contains a host of different questions and processes surrounding the researchers intentions and ethical standards. Following previous issues surrounding the commodification of hapū taonga from fellow hapū members, for cultural insiders the act of consultation involves 'going home' to the ancestral land base and meeting with ahi kā, koroheke, kuia and hapū members. Hapū can inquire the research; discuss the benefits and concerns for the hapu in relation to the research; how they can support the research; ways to work collaboratively; and establish the researchers whakapapa. The last process in particular is highly important, as it constitutes to how much of a right and access the researcher has to that knowledge, in accordance with tikanga Whanganui and if they have the right temperament to that knowledge, which is based on the intentions of the researchers abiding by the meanings of Whanganui kaiponu.

For members who do not whakapapa to the hapū, the same ethical process stipulated for hapū members or cultural insiders follows the same aforementioned process. However the process of gaining the trust of the hapū members will take time for the researcher and involves further inquiry into the researchers intentions and concerns regarding future uses of the knowledge that they bestow due to past actions imbued 
with colonial history. Hapū members have argued that there are beneficial aspects of cultural outsiders collaboratively studying hapū taonga in contexts such as intermarrying into the hapū; through not being raised on Rananā specifically; as well as general non-hapū members having interests in hapū taonga. These benefits include the unbiased perspectives towards inter-hapū and inter-iwi politics as well as viewing the ancestral environment through a different lens and perhaps seeing aspects that hapū members could not see or take for granted. Kaiponu ethics regarding cultural insiders and outsiders align closely with Bartunek and Louis (1996) and Dwyer and Buckle's (2009) viewpoint on insider/outsider joint research methods. They reiterate that cultural identities encompassing sameness or differences can provide a more multifaceted study (Dwyer and Buckle, 2009; Bartunek and Louis, 1996).

One of the collaborative parties that the researcher must consult with is the ahi kā. Ahi kā is a role for Ngāti Ruakā that includes continuous land occupation relating to caretakers of hapū taonga and tikanga marae (Tinirau et al, 2009). Ahi kā also reside on the ancestral land base or 'home' and are the keepers of hapū taonga, entrusted with important decision making processes. Therefore ahi kā must condone and support the research in order for it to progress, as they are central in the decision making processes and maintainence of the ethical standards for the research.

\section{Section 27: The pedagogical methods}

The pedagogical methods are pivotal and primarily oral, with the methods defining as the transmission, the learning and the performance of oral hapu taonga. Within the context of kaiponu ethics and framework, teaching oral hapū taonga requires again prior, ongoing and subsequent consent, consultation and permission from the 
implicating hapū, whānau and ahi kā regarding its practice and performance. Some of these important factors include to who it will be performed, or if it's knowledge transmission for selective retainment for a certain few as preservation. Both the right tutor and right person to learn must be chosen. The tutor must carry the knowledge already, have the right skill set as well as the right temperament. This tutor must also educate in appropriate ways that is for the benefit of that knowledge. Ngāti Ruakā participants in relation to what they did not want or what they had seen happen to kapa haka following unethical procedures discussed these criteria. Further influences on this criteria came from how they had been taught growing up, which was completely oral and learnt within their head and within their heart (Angeline Ann Haami, interview, 2 April 2017).

An additional desire regarding appropriate pedagogical methods relates to travelling and taking pupils to specific environmental sites that the oral hapu taonga either originated from or is referring too. Hapū members stated that this can frame and channel the time and world of the composer, to pay homage and to properly draw on the right emotive qualities when performing the oral hapū taonga. While this can be difficult to do and stated as the most ideal situation of learning and not a minimum requirement, it would help the performers to feel the mauri of the place and to picture what the oral hapū taonga is talking about. This highlights the politics of location, travelling and distance to remote marae or ancestral lands that are issues set amongst the back drop of contemporary Māori realties, particularly with its difficulties. Hapū members reiterated this difficulty and stated that these places that the oral hapū taonga talks about may have changed or no longer exist. 
While oral transmission through demonstration, repetition and extempore has been the most preferable and main mode of pedagogy for oral hapū taonga or waiata, technological and outside tools have been used by Ngāti Ruakā participants. Ngāti Ruakā has used technology in the past as smaller components to help connect present tamariki and rangatahi to oral hapū taonga. These can be considered as a kete of tools and include the technological tools of transcription (notating the melody), audio recordings (of past kapa haka performing) and writing the lyrics down (for example, on a black board) for a short time so that the learning group can memorize the song. Another tool that has been used as a selling point to get the younger hapū and iwi members interested is using outside western tonal harmonies such as vocal harmony work (three part and four part harmonies), that otherwise was not used in ancient oral hapū taonga. This has been accepted by some members of Ngāti Ruakā who teach kapa haka in that these tonal harmonies are everywhere today in popular music, therefore tamariki and rangtahi are already exposed and conditioned through their ear to have innate preconceived notions about harmony and pitch. However when learning old oral hapū taonga, harmony work is not used.

\section{Section 28: Sites of preservation}

Ngāti Ruakā has specified different sites that practice and encompass Whanganui kaiponu methods of preservation and these will be adapted for the kaiponu framework. The principal aspect involves going back to the home environment of the ancestral land base and having a connection to ahi kā, hapū and whānau. Ngāti Ruakā has specified three further sites of preservation that incorporate Whanganui kaiponu 
and these are through Wānanga, Taura Here and the Hui Aranga, ${ }^{32}$ which all operate currently. These sites of preservation not only align with Whanganui kaiponu in alleviating ethical concerns for hapū members, but these sites work to ensure that ahi tere and ahi mātaotao do not take place for future descendants (Tinirau et al, 2009), which helps to instill a type of legacy left by hapū oral history. These sites can further help the pupils learn in covert ways through subtle influences of an "osmosis" effect from the surrounding environment as well as their whānau members who are also participating. This has been argued as an important method by Ngāti Ruakā, which seeks to normalise and produce encouragement within a communal wānanga learning environment.

Hui Aranga, as a site of preservation, requires further exploration on how this can work alongside kaiponu. This cultural event is a yearly weekend gathering of Catholic Māori clubs where kapa haka is publicly performed. It is perhaps the selective nature of Whanganui kaiponu at work within this site, as āhi kā, koroheke and kuia have direct control of specific waiata and haka that is performed by their mokopuna, which aligns with the ethical process set out within kaiponu previously. However this is spectulative and does necessitate further examination.

\section{Summary}

This chapter discussed the intersections between Ngāti Ruakā participant views and the earlier literature regarding culturally appropriate hapū waiata methodologies and to answer the overall research question. This chapter is divided into three parts, examining the three broader themes that have been re-contextualised within the

\footnotetext{
32 The meanings of these three sites of preservation were explained and explored within the previous chapter (See page 106).
} 
previous literature. The three parts examine; the significance of orality, which examined oral history, waiata as hapū oral taonga, ethnomusicology categorisations and phenomenology; the influences of technologies, which explored transcription as a technology, reciprocity, digital and audio technology, online and digital repositories, copyright and intellectual property; and the last section looked at the rationale for adapting Whanganui kaiponu as kaiponu, a framework for the safe preservation and pedagogy or oral hapū taonga within the context of the hapū, Ngāti Ruakā. This last section examined the kaiponu framework through establishing the ethical process through consultation; cultural insiders and outsiders; ahi kā decision-making processes; pedagogical methods; setting a kete of tools (technology); and the sites of preservation. This last section aimed to answer the overall research question relating to the adaption of kaiponu as a culturally appropriate framework for waiata (oral hapū taonga) regarding preservation for Ngāti Ruakā. 


\section{Chapter 7.}

\section{Conclusion}

You open your eyes and our eyes were the window for the waiata that, you know, nga waiata (Josephine Takarangi-Firmin, interview, 2 April 2017).

\section{Introduction}

This chapter concludes on the overall findings of the thesis and reflects on the primary research question. The research question explored relevant literature and Ngāti Ruakā perspectives on oral hapū taonga and waiata within the context of preservation and kaiponu. This chapter will be divided into three parts, which include: 1) the primary research question; 2) the strengths and limitations of the research; and lastly 3) the areas in need for future study brought about through this research.

\section{Section 29: The research questions}

The primary question asked the ways in which Ngāti Ruakā prefer to preserve and transmit their waiata (hapū taonga) and how could this be achieved through culturally appropriate hapū methodologies and frameworks. There were a multitude of answers to this primary research question from hapū participants and within the pertinent literature; however, Ngāti Ruakā argued that adapting Whanganui kaiponu is vital for the preservation of their knowledge (oral hapū taonga and waiata), as this has been the preferred framework for some time within Ngāti Ruakā. The underpinnings of this framework were explored comprehensively within the two previous chapters about 
Ngāti Ruakā, ${ }^{33}$ and within the discussion chapter $^{34}$ that analysed the hapū participant views within the context of the literature. ${ }^{35}$

Kaiponu as an oral hapū taonga or waiata preservation framework for Ngāti Ruakā is created from the basis of Whanganui kaiponu as a selective treatment of knowledge, with its theoretical notions underpinned by the hapū participant views and its application stipulated through three key facets. These three key facets include the ethical process, pedagogical methods and lastly, the sites of preservation. These areas were comprehensively explored within the discussion chapter.

The three key facets within the kaiponu ethical framework set very specific requirements that are underpinned by Ngāti Ruakā values, beliefs and principles. These facets are significant for waiata study because they derive from a hapu perspective. Additionally, these facets highlight how categories for hapū waiata do not stem from a western categorisation by genre, and thus genre does not stipulate learning requirements, but rather tikanga Whanganui does.

The first key facet was the ethical process through the importance of time spent enquiring, consultating and observing as well as going through different processes whether or not the researcher is a hapū member. Ahi kā are crucial in guiding and permitting the research inquiry as well. The second key facet draws on past, present and future pedagogical methods to best teach oral hapū taonga or waiata that aligns with Whanganui kaiponu. These include a kete of tools that utilise digital, audio and

\footnotetext{
33 See page 64.

34 See page 87.

35 See page 17.
} 
written forms of technology (as minor tools) as well as the importance of invoking the environmental influences. These help to contextualise the kaupapa of certain hapū oral taonga or waiata that can influence the performance and memorisation of that waiata. Hapū members acknowledged that the environmental tool is the most ideal situation and they understand the difficulty involved in travelling, but going to the places that the waiata or oral hapū taonga refers to can be significant to learning. The third and last key facet involved the sites of preservation. These sites again, incorporate the importance of the home environment as well as three physical and social events of Wānanga, Taura Here and Hui Aranga. These sites of preservation align with Whanganui Kaiponu and were viewed by participants as being practical efforts towards oral hapū taonga or waiata preservation and pedagogy.

\section{Section 30: The strengths and limitations of the research}

The strength of this thesis and the research process comes directly from the support and consent of the hapū, Ngāti Ruakā, as this study would not have progressed without their permission and guidance. Not only have they provided their support, ${ }^{36}$ but they have also given their time, knowledge, lived experiences and stories for which I am privileged to have had access, been able to listen and record them for this study and for their future descendants. I was also able to have a reasonable pool of participants (12 in total), which gave wider and varying hapū perspectives from different age groups, despite the majority of the participants being koroheke and kuia.

The limitations of this thesis was the year-long time constraints, as it would have been insightful and beneficial for a follow up focus group interview involving all of the

\footnotetext{
36 See page 132.
} 
participants. One factor was the challenges of planning within set hapū events (such as Waitangi weekend). Additionally, there were either more questions that came from the interviews or further aspects that could have been built upon. This was found in three ways: the significance and influences of the rural hapū ancestral land base environment within the context of Māori contemporary realities for Māori living in urban settings; oral hapū taonga or waiata categorisations within contemporary kapa haka performance spaces from koroheke and kuia perspectives; and lastly, the importance of te reo proficiency within the context of waiata or oral hapū taonga pedagogy and learning. These further questions that arose from the study are noteworthy in terms of their potential for future research into hapū waiata.

\section{Section 31: Future study}

There are several areas for future study that have been conveyed within this thesis and the research process, and they are explored within the discussion chapter in accordance with the subject areas. ${ }^{37} \mathrm{~A}$ few of these areas relate to the subjects that were touched on previously within the limitations of the research. These areas in particular can be studied within different disciplinary contexts such as ecomusicology (the musical and the ancestral land base environment), Māori studies (te reo proficiency) as well as education (pedagogical and learning outcomes). However, a more overt area for future study that was expressed during the interview process with urgency is the examining of oral hapū taonga or waiata legal frameworks, specifically regarding copyright and intellectual property.

\footnotetext{
37 See page 87.
} 


\section{Bibliography}

Andersen, J. C. (1923) An Introduction to Maori Music, Transactions of the New Zealand Institute, (54), 18th June 1923, pp. 743-762.

Andersen, J. C. (1924) Maori Music, Transactions of the New Zealand Institute, (55), 28th Aug 1924, 689-700.

Andersen, J. C. (1934) Maori Music with its Polynesian Background, New Plymouth: Thomas Avery \& Sons Ltd.

Andersen, J. C. (1946) Polynesian Literature - Maori Poetry (Waiata and Tangi), New Plymouth: Thomas Avery \& Sons Limited.

Apou, M. (2003) Ko te ahikā, Waiata-ā-ringa, performed by Aotea Utanganui at the Te Matatini National Kapahaka Festival, 24-27 February 2005: Palmerston North.

Bartunek, J.M., and Louis, M.R., (1996) Insider/outsider team research, Thousand Oaks, CA: Sage Publications.

Benton, R. A. (1981) The Flight of the Amokura: Oceanic Languages and Formal Education in the South Pacific, Wellington: New Zealand Council for Educational Research.

Berger, H. M. (2010) Stance: Ideas About Emotion, Style, and Meaning for the Study of Expressive Culture, Wesleyan University Press, [Online] ProQuest Ebook Central, available at: http://ebookcentral.proquest.com/lib/VUW/detail.action?docID=776794. [Accessed 24 March 2017].

Best, E. (2005) Games and Pastimes of the Maori, 2005 edition, Wellington: Te Papa Press. 
Bevan-Brown, J. (1998) 'By Māori, for Māori, about Māori - is it enough?', A paper presented at Te Oru Rangahau Māori Research and Development Conference, Massey University, Palmerston North.

Binney, J., Chaplin, G. (1986) Ngā Mōrehu: The Survivors, Auckland: Oxford University Press.

Bishop, R. (1996) Whakawhanaungatanga: Collaborative research stories, Palmerston North, NZ: The Dunmore Press Ltd.

Bishop, R (1998) 'Freeing ourselves from neo-colonial domination in research: A Maori approach to creating knowledge', International Journal of Qualitative Studies in Education, 11(2), 199-219.

Bishop, R. (2005) 'Freeing ourselves from neocolonial domination in research: A Kaupapa Māori approach to creating knowledge', in N. K. Denzin., Y. S. Lincoln., eds., The handbook of qualitative research, 3rd Ed, Thousand Oaks, CA: Sage.

Boast, R., Erueti, A., McPhail, D., and Smith, N. (2004) Māori Land law, 2nd Ed, Wellington: LexisNexis.

Boyatzis. R. (1998) Transforming qualitative information: Thematic analysis and code development, Sage: Thousand Oaks, CA.

Braun, V., and Clarke, C. (2006) 'Using Thematic analysis in psychology', Qualitative Research in Psychology, 3, 7-11.

Buck, P. (1950) The coming of the Māori, 2nd Ed, Wellington: Māori Purposes Fund Board; Whitcombe \& Tombs.

Davis, M. E. (1992) 'Careers, alternativecareers, and the unity between theory and practice in ethnomusicology,' Ethnomusicology, 36(3), 361-87. 
DiCicco-Bloom, B., Crabtree, B. F. (2006) 'The Qualitative Research Interview', Medical Education, 40, 341-321.

Downey, G. (2002) 'Listening to Capoeira: Phenomenology, Embodiment, and the Materiality of Music', Ethnomusicology, 46(3), 487-509.

Durie, M. (2003) Nga kahui pou: Launching Maori futures, Wellington: Huia Publishers.

England, N. M. (1964) 'Symposium on Transcription and Analysis: A Hukwe Song with Musical Bow', Ethnomusicology, 8, 77-213.

Fereday,. J. and Muir-Cochrane, E. (2006) Demonstrating rigor using thematic analysis: A hybrid approach of inductive and deductive coding and theme development, International Journal of Qualitative Methods, 5(11), 1-11.

Fernandez, C. A. (2015) Whakawhirinakitanga Ahua: Exploring a Māori Model of health Service Delivery, Thesis (PhD), Massey University.

Finnegan, R. (1977) 'Some Oral Tradition is Oral Literature', In S. Vatu., ed., Na Veitalanoa Me Baleta Na I Tukutuku Maroroi - Talking About Oral Traditions, Suva: Fiji Museum, 13-25.

Finnegan, R., Orbell, M. (1995) Preface in R. Finnegan \& M. Orbell (Eds.), South Pacific Oral Traditions, Bloomington and Indianapolis: Indiana University Press, 1-5.

Firth, R. (1959) Economies of the New Zealand Māori, 2nd Ed, Wellington: Government Printer.

Frith, H., Gleeson, K. (2004) 'Clothing and embodiment: Men managing body image and appearance', Psychology of men and masculinity, 5(1), 40-48. 
Gillies, A., Tinirau, R., Mako, N. (2007) 'Whakawhanaungatanga-Extending the networking concept', He Pukenga Kōrero: A Journal of Māori Studies, 8(2), $29-37$.

Grey, G. (1853) Ko Nga Moteatea Me Nga Hakirara O Nga Maori, Wellington: Robert Stokes.

Grey, G. (1857a) Ko Nga Waiata Maori, London: Trübner \& Co.

Grey, G. (1857b) Ko nga Whakapepeha me nga Whakaahuareka a nga Tipuna o Aotea-Roa-Proverbial and Popular Sayings of the Ancestors of the New Zealand Race, Cape Town: Saul Solomon \& Co.

Grey, G. (1971) Nga Mahi a Nga Tupuna, 4th edition, Wellington A.H. \& A.W. Reed Ltd.

Grey, G. (n.d.) GNZMA AL, $761 A L$, Alexander Turnbull Library, [Online] unavilable, [accessed 11 August 2017].

Haami, M. (2015) Waiata aroha ki te Awa: Reclaiming past wisdom, the influence of Western music and worldviews on waiata from the Whanganui awa, Unpublished thesis (Honours), Otago University.

Hellier-Tinoco, R. (2003) 'Experiencing people: Relationships, Responsibilities and Reciprocity', British Journal of Ethnomusicology, 12(1), 19-34.

Henige, D. (1982) Oral Historiography, New York: Longman Group Limited.

Herbert, R. (2010) 'Harris M. BERGER, Stance: Ideas About Emotion, Style, and Meaning for the Study of Expressive Culture', Volume! [Online], available at: http://volume.revues.org/3583 [accessed 24 March 2017]. 
Hill, P. H. (1991) 'Learning from Outsider Within: The Sociological significance of Black Feminist Thought', Beyond Methodology Feminist Research as Lived Research, eds., M. M. Fonow., and J. A. Cook., Bloomington: Indiana University Press.

Holmes, P., Holmes, C. (2012) 'The Performer's Experience: A case for using qualitative (phenomenological) methodologies in music performance research', Musicae Scientiae, 17(1), 72-85.

Holt, F. (2008) 'Perspectives on Musicology Chapter 1c - A View from Popular music Studies' in H. Stobart., J. Bailey., M, Bigenho., eds., Europea: Ethnomusicologies and Modernities: The new (Ethno)Musicologies, 40-47, USA: Scarecrow Press.

Jackson, M. (1988) The Maori and the Criminal Justice System, A New Perspective: He Whaipaanga Hou, Wellington: Department of Justice.

Jensen, K. (2015) 'The significance and pedagogic applications of the vocal breakthrough. Part one: Conditions and stages', Journal of Singing, 72(2), [Online], available at: go.galegroup.com.helicon.vuw.ac.nz/ps/i.do?p=AONE\&sw=w\&u=vuw\&v=2 . 1\&it=r\&id=GALE\%7CA435755610\&asid=ad1bcf41c7c99803bc10acd7ad67a 342 [accessed 2 March 2017].

Jensen, K. (2016) 'The significance and pedagogic applications of the vocal breakthrough. Part two: The role of attention', Journal of Singing, 72(3), [Online], available at: go.galegroup.com.helicon.vuw.ac.nz/ps/i.do?p=AONE\&sw=w\&u=vuw\&v=2 . 1\&it=r\&id=GALE $\% 7 C A 439998739 \& a s i d=90 a 0 a 7 c 96227 \mathrm{c} 47853 \mathrm{a} 1829 \mathrm{~b} 4 \mathrm{bb} 8$ d2e8 [accessed 2 March 2017]. 
Jones, P. T. (1965) Te Ao Hou The Maori Magazine: Te patere a Ngawaero, June, [Online], available at: http://teaohou.natlib.govt.nz/teahou/image/Mao51Te/Mao51TeA020.html [accessed 10 January 2017].

Ka'ai-Mahuta, R. (2010) He Kupu tuku iho mō tēnei reanga: A critical analysis of waiata and haka as commentaries and archives of Māori political history, unpublished thesis, $(\mathrm{PhD})$, Auckland University of Technology.

Ka'ai-Mahuta, R. (2012) 'The use of digital technology in the preservation of Māori Song', Te Kaharoa, 5(1), [Online] available at: https://www.tekaharoa.com/index.php/tekaharoa/article/view/98 [accessed 11 August 2017].

Ka'ai-Mahuta, R., Ka'ai, T. M., \& Moorfield, J., eds. (2013) Kia Rōnaki: The Māori Performing Arts, Auckland: Pearson.

Kawharu, I. H. (1977) Māori land tenure: Studies of a changing institution, Oxford, Oxford University Press: United Kingdom.

Kisliuk, M. (1997) ‘(Un)doing fieldwork: Sharing songs, sharing lives’, in G. F. Barz., T. J. Cooley (eds), Shadows in the field: New perspectives for fieldwork in Ethnomusicology, 23-44, New York: Oxford University Press.

Leavy, P. (2011) Oral history: Understanding qualitative research, Oxford University Press.

Loftland, J., and Loftland. L. H. (1984) Analyzing social settings, Belmont, CA: Wadsworth Publishing Company Inc. 
Mahuika, R. (2009) ‘The Value of Oral history in a Kaupapa Māori Framework', In Harris, A., A. T. Somerville., \& R. Higgins eds., Te Pouhere Kōrero 3: Māori History, Māori People, Wellington: Victoria University and Puhi Princess Press, 91-104.

Māori Dictionary. (2017) Kaiponu, [Online] available at: http://maoridictionary.co.nz/search?idiom $=\&$ phrase $=\&$ proverb $=\&$ loan $=\&$ hist LoanWords=\&keywords=kaiponu [accessed 11 August 2017].

Māori Land Court. (1900) Whanganui minute book no. 44.

Māori Land Court. (1901) Whanganui minute book no. 47.

Māori Land Court. (1909) Whanganui minute book no. 59.

Marian-Bălaşa, M. (2005) 'Who Actually Needs Transcription? Notes on the Modern Rise of a Method and the Postmodern Fall of an Ideology', The World of Music, 47(2), 5-99.

McLean, M., Orbell, M. (1975) Traditional Songs of the Maori, Auckland: Auckland University Press.

McLean, M. (1989) 'Sound archiving and problems of dissemination of waiata', In R. Selby., \& A. J. Laurie., eds., Māori and Oral tradition: A Collection, Republished in 2005, Palmerston North: Massey University, 62-69.

McLean, M. (1996) Maori Music, Auckland: Auckland University Press.

McLean, M., Orbell, M. (2004) Traditional Songs of the Maori, 3rd edition, Auckland: Auckland University Press.

McLean, M. (2006) Pioneers of ethnomusicology, Auckland: Llumina Christian Books.

McLean, M. (2013) To Tatau Waka: In Search of Maori Music, Auckland: Auckland University Press. 
McNeil, M. (2013) I Am The River, [documentary for 'Witness'], [Online] available at: http://www.aljazeera.com/programmes/witness/2013/09/i-am-river201392410212172573.html

Doha, Qatar: Aljazeera Productions.

McRae, J. (2004) 'Ngā tuhituhinga reo Māori - Literature in Māori', in T. M. Ka'ai., J. C. Moorfield., M. P. J. Reilly., S. Mosley (eds.), Ki te Whaiao: An Introduction to Māori Culture and Society, Auckland: Pearson Education, 133-138.

McRae, J. (2017) Maori Oral Tradition: He Korero no te Ao Tawhito, Auckland: Auckland University Press.

Mead, H. (2003) Tikanga Māori: Living by Mãori Values, Wellington: Huia Publishers.

Mikaere, A. (1995) The balance destroyed: Consequences for Māori Women of the Colonisation of Tikanga Māori, Hamilton: University of Waikato Press.

Milroy, W. (2008) 'Indicators of Tribal Identity in Aotearoa/New Zealand,' Te Kaharoa, 1(1), [Online] available at: https://ojs.aut.ac.nz/tekaharoa/index.php/tekaharoa/article/view/141 [accessed 11 August 2017].

Moorfield, J. C., Johnston, E. L. (2004) 'Te reo Māori - Origins and development of the Māori language' in T. M. Ka'ai., J. C. Moorfield., M. P. J. Reilly \& S. Mosley eds., Ki te Whaiao: An Introduction to Māori Culture and Society, Auckland: Pearson Education New Zealand Limited, p. 36-49.

Mutu, M. (2009) 'The Role of History and Oral Tradition in regaining Fagin's Illgotten Gains: Settling Ngāti Kahu's Treaty of Waitangi Claims against the Crown', In Harris, A., A. T. Somerville., \& R. Higgins eds., Te Pouhere 
Kōrero 3: Māori History, Māori People, Wellington: Victoria University and Puhi Princess Press, 23-44.

Nepe, T. (1991) E hao nei e tenei reanga te toi huarewa tupuna: Kaupapa Māori, an Educational Intervention system, Unpublished MA Thesis, Education Department, University of Auckland.

Nettl, B. (1964) Theory and method in ethnomusicology, The Free Press, Collie New York: Macmillan Publishers.

Nettl, B. (1975) 'The state of research in ethnomusicology and recent developments', Current Musicology, 20, 67-78.

Nettl, B. (1983) The study of ethnomusicology: twenty-nine issues and concepts, Urbana: University of Illinois Press.

Ngata, A. T. (2004) Ngā Mōteatea Part I, 2004 edition, Translations by P. T. H. Jones, Auckland: Auckland University Press.

Ngata, A. T. (2005) Ngā Mōteatea Part II, 2005 edition, Translations by P. T. H. Jones, Auckland: Auckland University Press.

Ngata, A. T. (2006) Ngā Mōteatea Part III, 2006 edition, Translations by P. T. H. Jones, Auckland University Press: Auckland.

Ngata, A. T. (2007) Ngā Mōteatea Part IV, 2007 edition, Translations by H. M. Mead, Auckland: Auckland University Press.

Orbell, M. (1991) Waiata: Māori Songs in History, Auckland: Reed Books.

Orbell, M. (1995) The illustrated encyclopedia of Māori myth and legend, Christchurch: Canterbury University Press.

Patton, M. Q. (1990) Qualitative evaluation and research methods, 2nd Ed, Newbury Park, C.A.: Sage Publications. 
Patton, M. Q. (2002) 'Interpretive Phenomenological Analysis’, In J. A. Smith., M. Osborn., eds., Qualitative Research and Evaluation Methods, 3rd Ed, Thousand Oaks, CA: Sage, 53-80.

Robbins, D. (2011) 'Phenomenology', in The Lyotard Dictionary, Edinburgh: Edinburgh University Press, 164-166

Royal, C. (1992) Te Haurapa: An Introduction to Researching Tribal Histories and Traditions, Wellington: Bridget Williams Books Limited.

Royal, C. (1998) 'Te Ao Mārama - A Research Paradigm’ in Te Pūnanawa Hauora, ed., Te Oru Rangahau: Māori Research and Development Conference, 7 -9 July, Te Pūtahi-ā-Toi: School of Māori Studies: Palmerston North, Massey University, 78-86.

Royal, T. A. C. (2003) The Woven Universe, Otaki New Zealand: Estate of Rev Māori Marsden.

Royal Commission of Inquiry. (1980) The Māori Land Courts: Report of the Royal Commission of Inquiry, Wellington: Government Printer.

Rikys, P. (2001) The valuation for and rating of Māori land, Waiheke: Te Ngutu o Te Ika.

Salmond, A. (1976) Hui: A study of Māori ceremonial gatherings, 2nd Ed, Auckland: Reed Books.

Sheehy, D. (1992) 'A few notions about philosophy and strategy in applied ethnomusicology,' Ethnomusicology, 36(3), 323-36.

Simon, M. T. (1986) Taku Whare E: My Home, My Heart, Volume 1, Whanganui: Moku Whanau Trust.

Sinclair, D. (1981) 'Land: Māori view and European response', in M. King., eds., Te ao hurihuri: Aspects of Māoritanga, 3rd Ed, Auckland: Reed Books, 86-106. 
Smith, G. (1997) The development of Kaupapa Māori: Theory and Praxis, Unpublished Ph.D Thesis, Education Department, University of Auckland.

Smith, L. (1999) Decolonizing Methodologies: Research and Indigenous Peoples, London: Zed Books.

Smith, L., Reid, P. (2000) Māori Research Development Kaupapa Māori Principles and Practices: A Literature Review, [Online], available at: http://www.rangahau.co.nz/kaupapa-maori-articles/189/ [accessed 10 January 2017].

Smith, J. A., \& Osborn, M. (2008) 'Interpretative phenomenological analysis', in J. A. Smith., eds., Qualitative psychology: A practical guide to research methods. London: Sage.

Smith, N. (1942) Native custom and law affecting native land, Wellington: Māori Purposes Fund Board.

Smith, N. (1960) Māori land law, A.H. \& A.W. Auckland: Reed Books.

Sole, T. (2005) Ngāti Ruanui: A History, Wellington: Huia Publishers.

Statistics, New Zealand. (2013) Speakers of te reo Māori, [Online] available at: http://www.stats.govt.nz/browse_for_stats/snapshots-of-nz/nz-progressindicators/home/social/speakers-of-te-reo-maori.aspx [accessed 11 August 2017].

Taylor, N., eds. (1959) Early Travellers in New Zealand, London: Oxford University Press.

Taylor, R. (1855) Te Ika a Maui, London: Wertheim and Macintosh.

Taylor, T.D. (1997) Global pop: World music, world markets, London: Psychology Press.

Te Mana Matua Iwi. (1999) Mai i te kaahui maunga ki Tangaroa: Awa Tupua 
Whanganui policy statement, Whanganui: Te Mana Matua Iwi.

Tinirau, R. S., Tinirau, R. P. K., Gillies, A., Palmer, F., Mako, N. (2007) A draft report prepared for the Rānana Māori Committee. Palmerston North: Te Au Rangahau (Māori Business Research Centre), Department of Management, Massey University.

Tinirau, R. S. (2008) 'He Ara Whanaungatanga: A Pathway Towards Sustainable, Inter-generational, Research Relationships: The Experience of Ngāti Ruaka/Ngāti Hine', in Te Tatau Pounamu, The Greenstone Door Traditional Knowledge and Gateways to Balanced Relationships Conference, 8 - 11 June, Auckland, 295-304.

Tinirau, R. S. (2017) Te Kura i Awarua: Understanding, valuing and practicing tikanga in Māori businesses and organisations, $\mathrm{PhD}$, Massey University, Palmerston North.

Toitū Te Whenua. (1959) 'The struggle against fragmentation', Te Ao Hou: The New World Māori Writers' Issue, 28, 43-47.

Tūpara, H. N. T. H. (2009) He Urupounamu e Whakahaerengia ana e te Whānau: Whānau Decision Processes, PhD, Massey University, Palmerston North. Waitangi Tribunal. (1999) The Whanganui River report (Wai 167), Wellington: Waitangi Tribunal.

Whanganui Iwi and the Crown. (2014) Ruruku Whakatupua: Te Mana o Te Iwi o Whanganui.

Williams, D. V. (1999) Te kooti tango whenua: The Native Land Court 1864-1909, Wellington: Huia Publishers.

Wilson, C. (2007) Brief of evidence of Che Wilson for te iwi o Whanganui (Wai 167), 
Paper presented at the Whanganui District Inquiry, 12 September, Wai 903, Parikino Marae, Whanganui River.

Young, D. (1998) Histories from the Whanganui River: Woven By Water, Wellington: Huia Publishers. 


\section{Glossary}

Ahik $\bar{a}-$ Home fires burning and continual ancestral land occupation

Ahi tere - Unstable fire through relocation away from ancestral land base

Ahi mätaotao - Extinguished fire and severed connection to ancestral land base

Arapaki - Visual art or design (see tukutuku)

Awa - River but is commonly used to reference particularly the Whanganui River

Hap $\bar{u}-$ Sub-tribe

$H u i$ - Meeting consisting of a lot of people

Iwi - Tribe

Kaumātua-Elders (see Koroheke and Kuia)

Kawa - Refers to a set of protocol and customs regarding the marae and Kaupapa

Māori sub-strategy

Kete - Bag, however within this context it refers to the three bags of knowledge

Koha aroha - Gifts given to Māori communities as a way of thanking their

participation and generosity throughout the study

Kōrero pūrākau - Story telling

Koroheke - Elderly man

Kuia - Elderly women

Kupu - Phrases

Mana - Prestige

Manuhiri-Visitor and this role is pivotal during the welcome onto a marae also known as the pōwhiri

Marae - Place of dwelling or courtyard consisting of many Māori buildings

Mātauranga - Māori knowledge and/or epistemology 
Mōteatea - Genre of waiata and mostly refers to older waiata

Mokopuna - Grand child/children

Nga muka-a-taurawhiri-a-Hinengākau - The fibre of the plaited rope of Hinengākau

Ngā Rauru - Tribe south of the Taranaki region and north of Whanganui

Ngāti Tüwharetoa - Tribe from the Whanganui Awa and at the foot of Mount

Tongariro

$P \bar{a}-$ Fortified enclosure

Pōwhiri - The welcoming ceremony onto a marae

Rangatiratanga - Sovereignty or autonomy

Raupatu - Land confiscation

Tā moko - Tattoo

Tamariki-Children

Tāne - Men (' $\bar{a} '$ is pluralised)

Tangihanga - The funeral and mourning process

Taonga - gifts or treasures

Tapu - Sacred

Te Âti Haunui-a-Pāpārangi - Māori tribe from the Whanganui Awa

Te mita o Whanganui - The dialect of Whanganui

Tikanga - Māori protocol and customs

Tohunga-Experts within different disciplines of knowledge

Tukutuku - Visual art or design (see arapaki)

Tüpuna - Ancestors or grandparents (' $\overline{\mathrm{u}}$ ' is pluralised)

Türangawaewae - 'Right for the feet to stand'

Wāhine - Women (' $\bar{a}$ ' is pluralised)

Waiata-Māori song 
Whakairo - Carving

Whakapapa - Genealogy or ancestry

Whakataukī-Proverb

Whakatauāk $\overline{1}$ - Proverb with the intention of doing those verbal actions

Whakawhanaungatanga - The act of relating to others

Whanganuitanga - Refers to a personal ontological practice, identity and perspective on protecting the Whanganui Awa

Whānau - Family

Whanaunga - Kin or family relations 


\section{Appendix A. Consent forms}

\section{Section 1: Rānana Māori Committee consent form on behalf of Ngāti Ruakā}

9 August 2016

Meri Haami

17 Rosalie Terrace

Kevin Grove

Palmerston North 4414

Tēnā koe Meri, i runga i ngā tini āhuatanga o te wā iti nei.

Thank you for taking the time to address our hui of the Rānana Māori Committee and Rānana Marae Trustees, as well as our Ngāti Ruaka and Ngāti Hine hapū members who were present at the hui on Sunday 7 August at Rānana Marae, Whanganui River.

On behalf of the Rānana Māori Committee, Rānana Marae Trustees and those present at the hui, I write to formally endorse and support your doctoral research in ethnomusicology at Victoria University. We were excited to hear that together, we will co-construct a framework for documenting hapū waiata, which you will then implement through your doctoral study. I also confirm our availability to provide the necessary hapu and cultural guidance that will be required, given your research topic on waiata that belong to our hapū community. As discussed with you, we encourage you to make contact with $\mathrm{Dr}$ Te Tiwha Brendon Puketapu, who is a whanaunga and hapū member. He may also be willing to provide academic and cultural advice.

It is highly likely that some of the waiata and kōrero that may be shared with you may not have been published or shared before. There may also be requests from our hapū and your research participants to keep some of the kōrero that is shared with you private. Therefore, we would need to discuss how best this might be done, as well as ensure that the sanctity of our hapu knowledge is respected and maintained, and that protection mechanisims are in place for you, our hapū and the knowledge that may be imparted. However, these deliberations will be held when the time is right.

We wish you every success, and we look forward to working with you on this kaupapa rangahau.

Ngā mihi

\section{Rāwiri Tinirau}

Chair 


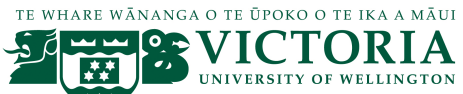

 \\ Decolonising western frameworks and methodologies in studying \\ waiata for Ngāti Ruakō \\ INFORMATION SHEET FOR PARTICIPANTS \\ Tēnā koutou, tēnā koutou katoa \\ Ko Te Āti Haunui-a- Pāpārangi te iwi \\ Ko Ngāti Ruaka te hapū \\ Ko Aotea te waka \\ Ko Whanganui te awa \\ Ko Ruapehu te maunga \\ Ko Meri Haami tōku ingoa \\ Tēnā koutou, tēnā koutou katoa
}

Thank you for your interest in this project. Please read this information before deciding whether or not to take part. If you decide to participate, thank you. If you decide not to take part, thank you for considering my request.

Who am I?

My name is Meri Haami and I am a Masters student in Ethnomusicology at Victoria University of Wellington. This research project is work towards my Masters thesis.

\title{
What is the aim of the project?
}

The aim of the project is to deconstruct western ways of researching waiata and to create a new way of research for studying waiata for our hapū, Ngāti Ruakā. Waiata as well as our oral histories carry our identities as hapū; including our whakapapa, tūrangawaewae and rangatiratanga, as well as the weight of our tīpuna; containing their deeds, decisions, sacrifices as well as their stories. In order to protect and preserve these qualities within our oral histories, it is vital to create an ethical way of researching ourselves.

This research has been approved by the Victoria University of Wellington Human Ethics Committee with the approval number: 0000023669. 


\section{How can you help?}

If you agree to take part I will interview you after the Rānana Marae Committee meeting Sunday the 2nd of April 2017 as apart of focus group hui. I will ask you questions about the preservation of waiata and the tikanga and framework within studying waiata from a Ngāti Ruakā perspective. The interview will take roughly an hour, however all participants within the focus group will decide where and how long the korero leads. I will record the interview and write it up later. There will be a moderator who can give everyone equal turns to speak and who can keep the korero on track. Participants can choose to leave the focus group discussion, however it will be impossible to what has been said to the point of the withdrawal.

\section{What will happen to the information you give?}

This research is confidential. This means that the researchers named below will be aware of your identity but the research data will be aggregated and your identity will not be disclosed in any reports, presentations, or public documentation. However, you should be aware that in small projects your identity might be obvious to others in your community.

Every participant within the small focus group hui will also be aware of your identity, however if you wish to be interviewed individually and separately, please contact me before April the 30th 2017 to organise a time and place for your interview.

Only my supervisors and I will read the notes or transcript of the interview. The interview transcripts, summaries and any recordings will be kept securely and destroyed after the yearlong research ends (Approx. 9/9/2017)

\section{Koha}

A donation of $\$ 250$ will be contributed towards Ngāti Ruakā marae as well as individual chocolates will be provided for participants on the day.

\section{What will the project produce?}

The information from my research will be used in my Masters thesis.

If you accept this invitation, what are your rights as a research participant?

You do not have to accept this invitation if you don't want to. If you do decide to participate, you have the right to:

- Choose not to answer any question;

- $\quad$ Ask for the recorder to be turned off at any time during the interview;

- $\quad$ Can withdraw from the study at any point;

- Ask any questions about the study at any time;

- Receive a copy of your interview recording.

- $\quad$ Read over and comment on a written summary of your interview;

- $\quad$ Agree on another name for me to use rather than your real name;

- Be able to read any reports of this research by emailing the researcher to request a copy. 
If you have any questions or problems, who can you contact?

If you have any questions, either now or in the future, please feel free to contact either:

Student:

Name: Meri Haami

University email address:

haamimeri@myvuw.ac.nz
Supervisor:

Name: Dr. Brian Diettrich

Role: Chief Supervisor

School: School of Music

Phone: +64 44639787

brian.diettrich@nzsm.ac.nz

\section{Human Ethics Committee information}

If you have any concerns about the ethical conduct of the research you may contact the Victoria University HEC Convener: Associate Professor Susan Corbett. Email susan.corbett@vuw.ac.nz or telephone +64-4-463 5480. 


\section{Decolonising western frameworks and methodologies in studying waiata for Ngāti Ruakā CONSENT TO INTERVIEW}

This consent form will be held until the end of the yearlong study.

Researcher: Meri Haami, School of Music, Victoria University of Wellington

- I have read the Information Sheet and the project has been explained to me. My questions have been answered to my satisfaction. I understand that I can ask further questions at any time.

- I agree to take part in an audio recorded interview.

I understand that:

- I may withdraw from this study at any point. Any information that I have provided will be returned to me or destroyed.

- The information I have provided will be destroyed after the research is finished. (Approx. the $9 / 9 / 2017)$.

- Any information I provide will be kept confidential to the researcher and the supervisor. I understand that the results will be used for a Masters report and a summary of the results may be used in academic reports and/or presented at conferences.

- My name will not be used in reports, nor will any information that would identify me.

- I would like a copy of the transcript of my interview.

- I would like a summary of my interview.

- I would like to receive a copy of the final report and have added my email address below.

Signature of participant:

Name of participant:

Date:

Contact details: 




MEMORANDUM

\begin{tabular}{l|l}
\hline TO & Meri Haami \\
\hline COPY TO & Dr Maria Bargh, Mr Brian Diettrich \\
\hline FROM & AProf Susan Corbett, Convener, Human Ethics Committee \\
\hline DATE & 9 December 2016 \\
\hline PAGES & 1 \\
\hline & $\begin{array}{l}\text { Ethics Approval: 23669 } \\
\text { Decolonising western frameworks and methodologies in studying } \\
\text { waiata from Ngati Ruaka. }\end{array}$ \\
\hline
\end{tabular}

Thank you for your application for ethical approval, which has now been considered by the Standing Committee of the Human Ethics Committee.

Your application has been approved from the above date and this approval continues until 9 September 2017. If your data collection is not completed by this date you should apply to the Human Ethics Committee for an extension to this approval.

Best wishes with the research

Kind regards

Susan Corbett

Convener, Victoria University Human Ethics Committee 